\title{
La Arqueta de las Ágatas de la Cámara Santa de la Catedral de Oviedo
}

\author{
César García de CAstro ValdéS \\ Dirección General de Patrimonio Cultural \\ Gobierno del Principado de Asturias \\ cesar.garciadecastrovaldes@asturias.org
}

\section{RESUMEN}

La Arqueta de las Ágatas es la tercera de las grandes joyas altomedievales conservadas en el tesoro de la Catedral de Oviedo. Su tratamiento historiográfico, sin embargo, está muy lejos de la celebridad obtenida por las dos cruces de orfebrería. Aprovechando la información obtenida en el proceso de restauración, este trabajo aspira a ofrecer una descripción detallada de la pieza y a establecer las líneas principales que debe abordar su estudio monográfico, desde la elección del formato hasta el destino originario.

Palabras clave: Arqueta de las Ágatas, Cámara Santa de la Catedral de Oviedo, orfebrería de la Alta Edad Media, Reino de Asturias.

\section{The Agate Casket in the Cámara Santa of the Cathedral of Oviedo}

\begin{abstract}
The Agate Casket is the third of the great jewels from the Early Middle Ages hold in the Treasury of the Oviedo's Cathedral. However, it has not been loant a historiographical attention comparable to that dedicated to both the two famous jewellery crosses. Drawing on the information obtained through the restoration process, this paper aims to offer a detailed description of the object, and to establish the main lines of its monographical study, from the choosing of its design to a proposal on its originary function.
\end{abstract}

Key words: Agate Casket, Holy Chamber, Oviedo's Cathedral, Early Middle Ages jewellery, Asturian Kingdom. 


\section{Introducción ${ }^{1}$}

Con este nombre -Caja o Arqueta de las Ágatas- se conoce una arqueta con forma de prisma rectangular y tapa en forma de tronco de pirámide, confeccionada en madera

1 En este lugar expreso mi agradecimiento al cabildo de la Catedral de Oviedo y en especial a su deán, D Benito Gallego, por las facilidades concedidas para el estudio de la joya. Igualmente a D. Pedro Díaz Gómez, por la ayuda en la toma de fotografías, y a D. Carlos Álvarez de Benito por su gentileza en compartir sus saberes, documentación y experiencia como restaurador de la pieza. Por último, a la sección de Madrid del Instituto Arqueológico Alemán, por la autorización para la publicación de fotografías de su archivo. Inserto a continuación la bibliografía específica sobre la pieza, haciendo abstracción de las menciones en manuales u obras de historia del arte general. A. DE MORALES, Viaje a los reinos de León, Galicia y Principado de Asturias, Madrid, 1765, pp. 80-81; J. AMADOR DE LOS RÍOS, "La Cámara Santa de la Catedral de Oviedo y sus más antiguos monumentos artístico-industriales", Monumentos Arquitectónicos de España, Madrid, 1877, pp. 41-42 (Edición facsímil, Oviedo, 1988); C. MIGUEL VIGIL, Asturias monumental, epigráfica y diplomática, Oviedo, 1887 (Edición facsímil, Oviedo, 1987), p. 19; M. GÓMEZ MORENO, Iglesias mozárabes. Arte español de los siglos IX al XI, Madrid, 1919, pp. 380-382 (Edición facsímil, Granada, 1998); V. JUARISTI, Esmaltes con especial mención de los españoles, Barcelona, 1933, pp. 168-169; H. SCHLUNK, "Arte asturiano", vol. II de Ars Hispaniae, Madrid, 1947, pp. 414-416; J. CUESTA FERNÁNDEZ y M. DÍAZ CANEJA, "El arca de las ágatas", Boletín del Real Instituto de Estudios Asturianos, 42 (1958), pp. 3-16; V.H. ELBERN, "Die fränkische Emailplatte von der Caja de las Ágatas in der Cámara Santa zu Oviedo", Symposium sobre cultura asturiana en la Alta Edad Media, Oviedo, 1967, pp. 125-142; G. HASELOFF, “Achatkästchen in der Cámara Santa zu Oviedo", Reallexikon der germanischen Altertumskunde, I, 1968, pp. 33 ss.; J. MANZANARES RODRÍGUEZ, Las joyas de la Cámara Santa, valores permanentes de Oviedo, Oviedo, 1972; J. FONTAINE, L'Art préroman hispanique, Sainte-Marie-de-la-Pierre-qui-vire, 1973, pp. 344-345; H. SCHLUNK, Las cruces de Oviedo. El culto a la Vera Cruz en el reino de Asturias, Oviedo, 1985, pp. 29-35; A. BONET CORREA, Arte prerrománico asturiano, Barcelona, 1987 ( $2^{\mathrm{a}}$ ed.), pp. 216-218; V. NIETO ALCAIDE, Arte prerrománico asturiano, Salinas, 1989, pp. 178-179; M.A. SEPÚLVEDA GONZÁLEZ, "El programa iconográfico de las cajas de Astorga y de las Ágatas", Cuadernos de Arte e Iconografia, II, 3 (1989), pp. 148-158; C. CID PRIEGO, "Las joyas prerrománicas de la Cámara Santa de Oviedo en la cultura medieval”, Liño, 9 (1990), p. 7-43, esp. pp. 18-20; G. HASELOFF, Email im frühen Mittelalter, Frühchristliche Kunst von der Spätantike bis zu den Karolingern, Marburg, 1990, pp. 84-85; C. CID PRIEGO, "Las Joyas prerrománicas de la Cámara Santa de la catedral de Oviedo en la cultura medieval (continuación)", Liño, 10 (1991), pp. 7-46, y "Las joyas prerrománicas de la Cámara Santa y el inicio de la arqueología medieval en la época humanística", Actas del III Congreso de Arqueología Medieval Española, II, Oviedo, 1992, pp. 185-192; S. NOACK-HALEY, "Agate Casket", The Art of Medieval Spain, 500-1200, Nueva York, 1993, pp. 143-145; A. HEVIA BALLINA y R. PLATERO FERNÁNDEZ-CANDAOSA, "Caja de las ágatas", Orígenes. Arte y Cultura en Asturias, siglos VII-XV, Oviedo, 1993, pp. 247-249; F. DIEGO SANTOS, Inscripciones medievales de Asturias, Oviedo, 1994, pp. 60-61; C. GARCÍA DE CASTRO VALDÉS, Arqueología cristiana de la Alta Edad Media en Asturias, Oviedo, 1995; C. CID PRIEGO, Arte prerrománico de la monarquía asturiana, Oviedo, 1995, pp. 324-330; J. CUESTA FERNÁNDEZ, Guía de la Catedral de Oviedo, Oviedo, 1995 (2 $2^{\mathrm{a}}$ ed.) (Oviedo, 1957), pp. 201-204; C. CID PRIEGO, “Orfebrería prerrománica", El arte en Asturias a través de sus obras, Oviedo, 1996, pp. 437-452, y "Notas y recuerdos del robo, desperfectos y restauraciones de las joyas prerrománicas asturianas de la Cámara Santa de Oviedo", Anuario del Departamento de Historia y Teoría del Arte, 7-8 (1995-1996), pp. 25-43, y La Cruz de la Victoria y las joyas de la Cámara Santa, Oviedo, 1997, pp. 61-65, y "La reconstrucción de las joyas de la Cámara Santa", J. HEVIA BLANCO (ed.), La intervención en la arquitectura prerrománica asturiana, Oviedo, 1997, pp. 275-285; L. ARIAS PÁRAMO, La Cámara Santa de la catedral de Oviedo, Gijón, 1998, pp. 61-64; S. NOACK-HALEY, "Caja de las Ágatas", A. ARBEITER y S. NOACK-HALEY, Hispania Antiqua. Christliche Denkmäler des frühen Mittelalters, Mainz am Rhein, 1999, pp. 84-85 y 185-187, taf. 47c y 53; L. ARIAS PÁRAMO, Prerrománico asturiano. El arte de la monarquía asturiana, Gijón, 1999 (2 ed.), pp. 253-257; C. GARCÍA DE CASTRO VALDÉS, "Las primeras fundaciones", La catedral de Oviedo, II: Catálogo y Bienes Muebles, Oviedo, 1999, pp. 20-21; I. RUIZ DE LA PEÑA GONZÁLEZ, "Caja de las Ágatas", Maravillas de la España medieval. Tesoro sagrado y monarquía, León, 2000, n 85, p. 221; I.G. BANGO TORVISO, Arte prerrománico hispano. El arte en la España cristiana de los siglos VI al XI, vol. 8-2 de Summa Artis, Madrid, 2001, pp. 300-302; C. CID PRIEGO, "Las joyas prerrománicas asturianas de la Cámara Santa de la catedral de Oviedo consideradas y estudiadas en 
de ciprés, recubierta por láminas de oro repujadas, una lámina de plata grabada e igualmente repujada en la base, y placas de ágata, con abundante pedrería engastada sobre las láminas de oro. Aprovecha en el plano superior de la tapa una placa de oro, pedrería y esmaltes. Se conserva en la Cámara Santa de la Catedral de Oviedo, formando parte destacada de su tesoro sacro. Pese a ello, la atención que ha despertado en los once siglos de su existencia es muy inferior a la provocada por sus dos insignes compañeras de destino, las Cruces de los Ángeles y de La Victoria. Apenas estudiada monográficamente -salvo la placa superior reaprovechada- estas Jornadas parecen ocasión adecuada para acometer su análisis, aprovechando la información contenida en la memoria de la reconstrucción ${ }^{2}$.

\section{Noticias históricas y panorama historiográfico}

Al margen de la información transmitida por su propia inscripción, hasta el s. XIV no se conocen menciones de la pieza ${ }^{3}$. En 1305 se fecha un inventario de alhajas conteniendo reliquias, que describe la Arqueta de las Ágatas de este tenor:

la cultura a través de los siglos", La restauración de las joyas históricas de la Cámara Santa de Oviedo, 19771997. I. Estudios, Oviedo, 2002, pp. 9-201; R. PLATERO FERNÁNDEZ-CANDAOSA, "La Comisión para la restauración de las joyas históricas de la Cámara Santa”, La restauración de las joyas históricas de la Cámara Santa de Oviedo, 1977-1997. I. Estudios, Oviedo, 2002, pp. 221-271, y La restauración de las joyas históricas de la Cámara Santa de Oviedo, 1977-1997. II. Actas, Informes y Correspondencia y Documentación gráfica, Oviedo, 2002; M. FERNÁNDEZ AVELLO, "Crónica de un expolio histórico", La restauración de las joyas históricas de la Cámara Santa de Oviedo, 1977-1997. I. Estudios, Oviedo, 2002, pp. 203-219; C. ÁLVAREZ DE BENITO, "Proceso de restauración. 3. Caja de las Ágatas", La restauración de las joyas históricas de la Cámara Santa de Oviedo, 1977-1997. I. Estudios, Oviedo, 2002a, pp. 399-438; C. BURGOS, "Imágenes y Tesoros de la Cámara Santa", Luces de peregrinación. Sede real y sede apostólica, Oviedo, 2004, pp. 54-55; L. ARIAS PÁRAMO, "Caja de las Ágatas o de las Calcedonias", Enciclopedia del prerrománico en Asturias, Aguilar de Campoo, 2007, II, pp. 685-691; C. GARCÍA DE CASTRO VALDÉS, Arte prerrománico en Asturias, Oviedo, 2008 ( $3^{\mathrm{a}}$ ed.), pp. 163-164; H. SCHLUNK, "Las cruces de Oviedo. Contribución a la historia de la orfebrería en el Norte de España en los siglos IX y X”, H. SCHLUNK y V.H ELBERN, Estudios sobre la orfebrería del reino de Asturias, Oviedo, 2008, pp. 37-117 (versión original inglesa: "The Crosses of Oviedo", The Art Bulletin, XXXII (1950), pp. 91-114); V.H. ELBERN, "Un fragmento de relicario franco en Oviedo, la bolsa de Enger en Berlín y su contexto", H. SCHLUNK y V.H. ELBERN, Estudios sobre la orfebrería del reino de Asturias, Oviedo, 2008, pp. 178-208 (versión original alemana: "Ein fränkisches Reliquiarfragment in Oviedo, die Engerer Burse in Berlin und ihre Umkreis", Madrider Mitteilungen, 2 (1961), pp. 183-204; reed. facsímil: P. SKUBISZEWSKI (ed.), Fructus Operis, Regensburg, 1998, pp. 157-189); y A. ARBEITER y L. ARIAS PÁRAMO, "Condicionantes histórico-artísticos de las cruces de Oviedo y su posterior restauración”, F.J. FERNÁNDEZ CONDE y C. GARCÍA DE CASTRO VALDÉS (eds.), Poder y Simbología en Europa, siglos $V I I-X$, anejo n 2 de Territorio, Sociedad y Poder (2009), pp. 401-415.

2 Como estudios específicamente dedicados a la caja conocemos solamente la monografía de Elbern (1961) sobre la placa superior, a la que se debe la resonancia internacional de esta pieza, el trabajo de alcance mucho menor de Cuesta y Díaz Caneja, igualmente aparecido en 1961, ligeramente anterior al de Elbern, y el artículo de Sepúlveda González sobre el programa iconográfico (1989). Es sintomático del desconocimiento entre los especialistas la ausencia de toda alusión a la caja como tal, al margen de la placa de la tapa, en la gran síntesis de P. LASKO, Ars sacra 800-1200, Londres, 1972 (2ª ed. Yale, 1995; ed. española, Madrid, 1999).

3 La historiografía de las joyas altomedievales asturianas fue objeto de atención continuada por parte de C. Cid Priego desde 1990 a 2002. Vid. C. CID PRIEGO, op. cit. (1990 y 1991), pp. 8 y 22, quien afirma que no existen menciones medievales de la misma. 
"una arca de iaspes cubierta doro en que disen que ias la fronte de san Iohan babtista e el braço de santo estevano".

Ochenta años después, en 1385, el Libro Becerro de San Salvador (ACO, Ms 9), mandado componer por el obispo Gutierre de Toledo, describe nuevamente la caja, en estos términos:

"una arca de oro guarnida de jaspe con piedras en que iasen estas reliquias. de la fronte de san iohan bavtista. et del braço diestro de santo estevano. E de los huesos de los ynocentes. E de las espinas de la corona de nuestro Señor iehsu xpto e de lino domini"4.

El tercer testimonio medieval está fechado el 14 de junio de 1465 y corresponde a la publicación de los privilegios de la Cofradía de la Cámara Santa, donde se relaciona el contenido de reliquias de la misma. La referencia a la arqueta sigue a la lista de piezas del Arca Santa:

"Iten es ende una arca preçiosa de oro e de piedras preçiosas, de la fronte de Sant Juan Bautista e de los sus cabellos. Iten las manos del sennor Santo Estevan, el primero mártir"s.

La primera noticia publicada se debe a Ambrosio de Morales ${ }^{6}$. Años después, a fines del XVI la menciona el jesuita Luis Alfonso de Carvallo ${ }^{7}$ y más adelante se refie-

4 E. LÓPEZ FERNÁNDEZ, Las reliquias de San Salvador de Oviedo, Oviedo, 2004, pp. 126-128, n. 3942, publica el texto de los dos inventarios. 1305: Archivo Capitular de Oviedo (ACO), Cámara Santa, legajo I, Caja 86: Documentos, f. 9v-10r; 1385: ACO, Cámara Santa, legajo I, Caja 86: Documentos, f. 10r-11r. Esta relación de documentos responde a un manuscrito compilatorio conservado en el Archivo Capitular Ovetense, elaborado al parecer por Moisés Díaz Caneja, archivero en las décadas de 1940 y 1950. Cf. E. LÓPEZ FERNÁNDEZ, op. cit., 2004, p. 281. El catálogo de los pergaminos del Archivo Capitular (S. GARCÍA LARRAGUETA, Catálogo de los pergaminos de la Catedral de Oviedo, Oviedo, 1957), no recoge referencia alguna al inventario de 1305. El de 1385 corresponde a los folios 165-174 del Libro Becerro, dedicados al inventario de las arcas de las reliquias. $C f$. F.J. FERNÁNDEZ CONDE, Gutierre de Toledo, obispo de Oviedo (1377-1389). Reforma eclesiástica en la Asturias bajomedieval, Oviedo, 1978, p. 274, n. 104.

5 S. GARCÍA LARRAGUETA, op. cit., 1957, pp. 384-385, nº 1144 (ACO, serie B, carp. 9, no 9); E. LÓPEZ FERNÁNDEZ, op. cit., 2004, pp. 95-97, 256.

6 A. DE MORALES, op. cit., 1765, pp. 80-81. Precisa la ubicación dentro del santuario de la Cámara Santa: en el testero, de derecha a izquierda, se encontraban el relicario que actuaba como pedestal de la Cruz de los Ángeles, en el centro, tapando la ventana oriental, la Cruz de la Victoria, y en el extremo izquierdo, la caja con el Santo Sudario. Sobre estos cofres y piezas, "un poquito más alto", se encontraba la Caja de las Ágatas, conteniendo en su interior "muchas reliquias menudas, y tienen lista de algunas dellas en tabla, que anda junta con el Arca (...) No se me abrió esta Arca, porque había tabla della fuera, y no parecía haber Reliquia insigne".

7 L.A. DE CARVAllo, Antigüedades y cosas memorables del Principado de Asturias, Madrid, 1695 (ed. facsímil, Salinas, 1984), pp. 186-187: "un Cofre rico de oro que llaman de las Calcedonias". Contenía entre otras reliquias "De la Serenísima Reyna de los Ángeles un pedacito de leche quaxada de sus virginales pechos, del tamaño de una avellana y muy blanco". C. CID PRIEGO, op. cit., 2002, p. 91 y n. 246, cita el acta de la visita llevada a cabo el 25 de enero de 1588 por el obispo Diego Aponte de Quiñones a la Cámara Santa, en la que se recoge el contenido relicario de la Caja de las Ágatas. Se conserva el acta impresa en J. PÉREZ DE PINEDO, Relación sumaria de las Santas reliquias que están en la Santa Catedral de San Salvador, de Oviedo, impresa en Madrid, 1621, que él mismo consultó en la Biblioteca Nacional, Madrid, Raros, 2/12.229. 
re a ella con mayor detenimiento en el párrafo dedicado a Fruela II $^{8}$. A fines del XVIII la vio Manuel Risco9. En 1761, la reordenación del relicario de la Cámara Santa a cargo del obispo Agustín González Pisador, confirió un notable protagonismo como contenedor relicario a la Arqueta de las Ágatas, pues acogió tres arquitas menores: una arquita de plata sobredorada con engastes de coral, con reliquias cristológicas; una caja de cristal de roca, con reliquias cristológicas; un "cofrecillo de plata" con reliquias cristológicas, mariológicas, de Moisés y del Bautista; y cinco "bolsas encarnadas" con reliquias apostólicas y del santoral ${ }^{10}$.

El arranque del estudio histórico-artístico de la pieza y su primera publicación científica se debe a José Amador de los Ríos, quien le dedica dos páginas de la monografía de la Cámara Santa incluida en el volumen de Monumentos Arquitectónicos de España referido a Asturias. Paralelamente ofrecía breve descripción y dibujo de la misma placa Ciriaco Miguel Vigil, en su corpus epigráfico y documental de Asturias $^{11}$.

El primer trabajo de trascendencia es mérito de Manuel Gómez Moreno. Lo constituyen los párrafos contenidos en Iglesias mozárabes (1919). Distingue por vez primera entre la placa adventicia de la tapa y la arqueta propiamente dicha, calificando a la primera como "estupenda obra bizantina" y señalando los, a su juicio, inequívocos rasgos mozárabes de la segunda, patentes en la paleografía de la inscripción, el formato de la caja de madera, el estilo de los repujados vegetales y el trazado en herradura de los arquillos calados del revestimiento áureo. Señalando el estrecho parentesco con la arqueta denominada de San Genadio, donada a la catedral de Astorga por Alfonso III y Scemena, estos párrafos han dominado hasta el presente el paradigma de estudio de la pieza, habiendo sido repetidos insistentemente en cuantos trabajos posteriores la han citado $^{12}$. No obstante, de modo paralelo, Albrecht Haupt apuntaba la raíz puramente germánica de la placa superior, enlazando con la orfebrería gótica atestiguada en torno al Mar Negro, prueba a su juicio de que "nirgends,

E. LÓPEZ FERNÁNDEZ, op. cit., 2004, pp. 134-152, esp. p. 134 y n. 71, y p. 147, estudia la visita de 1588 y extracta su texto, según esta misma publicación, cotejándola con la visita de 1 de marzo de 1626, ordenada por el obispo Juan de Torres Osorio. Al decir de E. LÓPEZ FERNÁNDEZ, op. cit., 2004, p. 147, en 1588 el Cofre de oro de las calcedonias contenía otros cinco recipientes contenedores de reliquias, a saber: la cajita del obispo Arias, dos cajitas redondas de madera, una bola de plata con algunas reliquias de la Virgen y San Pedro, y una cajita de plata cuya cubierta contenía la imagen de la Transfiguración. Sin embargo, en 1626, el mismo Cofre de las calcedonias albergaba una arqueta de plata blanca y lisa en la que se guardaba el fragmento de la Sábana Santa, y una cajita de coral y plata redonda que acogía los once fragmentos de lino Domini anteriormente conservados en el Cofre de San Sebastián y la Verónica (ibid., p. 154).

8 L.A. DE CARVALLO, op. cit., 1695, p. 253. La fecha en 911.

9 Asturias. Antigüedades concernientes a la región de los Astures Transmontanos desde los tiempos más remotos hasta el siglo X, Madrid, 1789 (Edición facsímil, Gijón, 1986), p. 262. Su predecesor H. FLÓREZ había tratado brevemente de la Caja de las Ágatas, a propósito de su biografía de la reina Nunilo, en Memorias de las Reynas catholicas..., Madrid, 1770, I, p. 90.

10 E. LÓPEZ FERNÁNDEZ, op. cit., 2004, pp. 155-157.

11 A través de Miguel Vigil conoció la inscripción E. HÜBNER, quien la incluyó con transcripción paleográfica en Inscriptiones Hispaniae Christianae, Berlín, 1869, p. 83, App. 256.

12 Años antes de la publicación de Iglesias mozárabes, su trabajo "De arqueología mozárabe", Boletín de la Sociedad Española de Excursiones, XXI (1913), pp. 89-116, esp. p. 94, había considerado “estupenda obra visigoda" la placa superior de la Caja de las Ágatas. 
auch in Deutschland nicht, hat sich rein altgermanisches Kunstgewerbe so lange noch lebendig erhalten" 13

El viernes 12 de octubre de 1934 una potente carga explosiva colocada en la parte occidental de la cripta de Santa Leocadia, planta inferior de la Cámara Santa, redujo a escombros buena parte del edificio prerrománico. Las joyas y enseres del tesoro catedralicio fueron sepultados por la masa de cascotes ${ }^{14}$. Pese a la violencia y magnitud del destrozo, las joyas apenas sufrieron daños de consideración, por feliz azar de la caída del material constructivo. Concretamente, la Caja de las Ágatas fue proyectada al exterior con la explosión, "abierta y su contenido se recogió en su mayor parte, apareciendo casi intacta" ${ }^{15}$. Por su parte, Cuesta Fernández y Díaz Caneja anotan que la caja

"fue la primera pieza que se encontró. Fue aventada por la explosión y recogida por los soldados que defendían la Catedral. A pesar de esto, los desperfectos no fueron grandes. La cubierta quedó separada de la parte baja y se rompieron y doblaron algunas ágatas. Se perdieron piedras y hubo abolladuras" ${ }^{16}$.

Tras la restauración de la inmediata posguerra, en la que se colocaron unas láminas de carey como sustitución de aquellas placas de ágata perdidas desde fecha desconocida ${ }^{17}$, la caja volvió a la exposición pública en la Cámara Santa, solemnemente inaugurada tras su reconstrucción en $1942^{18}$. Su estudio fue acometido en rápidos párrafos en sucesivos trabajos sobre el arte asturiano por Helmut Schlunk (1947, 1950, 1985; reed. 2008). Aunque no le dedicó ningún trabajo monográfico, Schlunk orientó el estudio de la placa reaprovechada de la tapa a la orfebrería carolingia, desechando definitivamente la adscripción bizantina de Gómez Moreno -compartida por Juaris-

13 A. HAUPT, Die älteste Kunst, insbesondere die Baukunst der Germanen, von der Völkerwanderungszeit bis zu Karl dem Grossen, Berlín, 1935 (3ª ed.) (Berlín, 1908), pp. 214-215.

14 Para los acontecimientos bélicos, A. LLANO ROZA DE AMPUDIA, Pequeños anales de quince dias, Oviedo, 1977 (2 $2^{\mathrm{a}}$ ed.) (Oviedo, 1935), pp. 30, 34, 47, 58 y 69; M. GÓMEZ MORENO, La catedral de Oviedo. Daños y pérdidas sufridas en este monumento durante los sucesos revolucionarios de octubre de 1934, Madrid, 1934, pp. 7-9.

15 Es esencial al respecto el informe redactado por Gómez Moreno para la Real Academia de la Historia, citado en nota anterior. Puede verse una síntesis de los sucesos y del proceso de reconstrucción de la Cámara Santa en C. GARCÍA DE CASTRO VALDÉS, op. cit., 1995, pp. 359-361.

16 J. CUESTA FERNÁNDEZ y M. DÍAZ CANEJA, op. cit. (1958), p. 16.

17 J. MANZANARES RODRÍGUEZ, op. cit., 1972, p. 18: “dos plaquetas y media en su frente, y otra más, en el dorso". La misma técnica de sustitución y enmascaramiento de lagunas se empleó en el anverso de la Cruz de la Victoria, donde los dos esmaltes verticales perdidos del brazo izquierdo fueron cubiertos con láminas triangulares de carey, que a su vez fueron retirados y sustituidos por esmaltes de nueva factura realizados motu proprio por el orfebre Werner Henneberger y aceptados por el Cabildo en 1971. Vid. J. MANZANARES RODRÍGUEZ, op. cit., 1972, p. 15, y R. PLATERO FERNÁNDEZ-CANDAOSA, op. cit., 2002, pp. 234-235. En la reconstrucción de 1982 se optó por retirar nuevamente estos esmaltes y sustituirlos, junto con los desaparecidos en 1977, por otros fabricados en el taller del monasterio de Santo Domingo de Silos. Cf. C. ÁLVAREZ DE BENITO, "Proceso de restauración. 1. La Cruz de la Victoria", La restauración de las joyas históricas de la Cámara Santa de Oviedo, 1977-1997. I. Estudios, Oviedo, 2002b, pp. 339-346.

18 Al respecto, J. CUESTA FERNÁNDEZ, Crónica del Milenario de la Cámara Santa, Oviedo, 1947. 
ti ${ }^{19}$ - y la de aquellos de sus discípulos (José Ferrandis, Emilio Camps, María Elena Gómez Moreno) que habían propuesto una cronología visigoda ${ }^{20}$.

En 1961 Victor H. Elbern elaboró un estudio monográfico sobre la placa adventicia de la tapa de la caja, publicado en Madrider Mitteilungen. Asumiendo desde el inicio que el tipo y decoración de la caja se insertaban en la órbita de las producciones cordobesas, su atención se dirigió a la placa incluida en la tapa. Estableció en primer lugar la naturaleza técnica de los esmaltes, clasificándolos como esmaltes hundidos (Senkschmelz). Reafirmó en consecuencia la pertinencia de la asociación con la bolsa de Enger y la primera encuadernación de Lindau, lo que le permitió postular un contexto cronológico a mediados o primera mitad del VIII y ligado a piezas elaboradas en torno a Salzburgo. A continuación relacionó iconográfica y topográficamente las figuraciones animales de las tres piezas orfebrísticas, constatando su coincidencia: cuatro representaciones de los tria genera animantium (cuadrúpedos, aves, peces/ reptiles). Por último, indagó en el sentido iconológico de la asociación de esquema cruciforme y tria genera animantium, estableciendo el criterio al parecer definitivo para la dilucidación de su significado: la Creación redimida por la Cruz. Concluye con una deducción sobre la función primitiva de la pieza, desechando todo uso profano y apuntando a su pertenencia a un contexto sacro, como parte de un relicario, o como relicario ella misma concebida.

Por su parte, y meses antes de la aparición del artículo de Elbern, los canónigos ovetenses José Cuesta Fernández y Moisés Díaz Caneja dieron a la imprenta en el Boletín del Instituto de Estudios Asturianos un artículo monográfico sobre la caja, en el que se contienen observaciones de interés. De mayor importancia por la profusión de datos que contiene en su brevedad fue el capítulo dedicado a la arqueta en el libro de Joaquín Manzanares sobre las joyas de la Cámara Santa, aparecido en 1972.

\section{La destrucción de 1977 y la reconstrucción}

En la noche del 9 al 10 de agosto de 1977 un ladrón llamado José Domínguez Saavedra asaltó la Cámara Santa ${ }^{21}$. El producto de su acción fue la completa destrucción de las tres joyas altomedievales del tesoro ovetense: Cruz de los Angeles, Cruz de la Victoria y Arqueta de las Ágatas. Fueron despojadas bárbaramente de sus revestimientos de lámina de oro y pedrería, que fueron arrugados y en algunos casos doblados y plegados violentamente, pues el destino previsto por el delincuente había sido destinarlos a la venta una vez fundidos. Detenido el autor por acción policial en Oporto el 13 de septiembre de 1977, y recuperado y devuelto a Oviedo el botín, se constituyó a instancias del Arzobispado ${ }^{22}$ una "Comisión para la restauración de

19 V. JUARISTI, op. cit., 1933, pp. 108-109: "placa de alveolado bizantino, de esmalte rojo translúcido".

20 Por ejemplo J. FERRANDIS, “Artes decorativas visigodas”, Historia de España dirigida por Ramón Menéndez Pidal, Madrid, 1940, III, pp. 679-680; M.E. GÓMEZ MORENO, Mil joyas del Arte español, Barcelona, 1947, I, n 129, pp. 68-69.

21 Para la reconstrucción de los hechos, M. FERNÁNDEZ AVELLO, op. cit., 2002, passim, esp. p. 213, a partir de las diligencias abiertas por la policía portuguesa tras la detención del delincuente.

22 R. PLATERO FERNÁNDEZ-CANDAOSA, op. cit., 2002, pp. 222-224. 
las joyas históricas de la Cámara Santa", encargada de la reconstrucción de las joyas, cuyas actas y documentación complementaria fueron publicadas en $2002^{23}$. Por azar histórico, la placa franca de la caja, que no había sido recuperada en 1977, fue identificada por la policía en Orense en agosto y devuelta a Oviedo en septiembre de $1989^{24}$.

La actuación de la Comisión abarca desde su constitución el 10 de noviembre de 1977 hasta su disolución el 24 de noviembre de $1997^{25}$. La Caja de las Ágatas empezó a restaurarse el 12 de junio de 1979, se dio inicialmente por terminada el 13 de septiembre de 1986, y se remató, tras su reanudación el 12 de marzo de 1990, el 12 de agosto de 1993, una vez que se reintegró a la arqueta reconstruida la placa franca asimismo restaurada ${ }^{26}$.

Domínguez Saavedra despojó a la caja de la placa superior, todas las láminas de oro y de la pedrería, pero dejó sin arrancar, adheridas al armazón de madera, las placas de ágata y la lámina de plata que cubre la base. El armazón no parecía haber sufrido daño alguno, salvo los inevitables ensanchamientos de los agujeros de los clavos provocados por la extracción violenta de ellos ${ }^{27}$. El ladrón hizo desaparecer el cierre postizo de la arqueta al arrancar las láminas delanteras, pero no se ocupó de las bisagras al formar parte del armazón de madera, que no despertó mayormente su curiosidad.

No se han publicado fotografías del estado inmediato de la placa argéntea de la base tras el asalto. A pesar de ello, los testimonios sin embargo, son unánimes en afirmar que no sufrió daño, lo que se verifica por la comparación entre el estado actual y el conocido por las fotografías anteriores a $1977^{28}$.

Los criterios de intervención aplicados a la Caja de las Ágatas fueron los mismos que rigieron la actuación en la Cruz de la Victoria, la primera en ser reconstruida y la más compleja de las piezas dañadas.

El estado de partida era deplorable en el revestimiento de oro y la pedrería, pero muy aceptable en el armazón de madera con las láminas de ágata incrustadas en él, y la placa inferior de plata, que no fueron agredidos. Las láminas de oro, plegadas,

23 Se trata de los dos volúmenes titulados La restauración de las joyas históricas de la Cámara Santa de Oviedo, 1977-1997. I. Estudios, Oviedo, 2002, y II. Actas, Informes y Correspondencia y Documentación gráfica, Oviedo, 2002. Por razones que desconozco, la obra, publicada por el Arzobispado de Oviedo con subvención de la Universidad de Oviedo y Cajastur, fue muy defectuosamente distribuida en librerías, por lo que ha permanecido sin apenas trascendencia científica.

24 R. PLATERO FERNÁNDEZ-CANDAOSA, op. cit., 2002, pp. 265-266.

25 La lectura de los capítulos de Platero Fernández-Candaosa y Álvarez de Benito y la consulta de los documentos del volumen II proporcionan un caudal enorme de noticias sobre los avatares de la Comisión, el desarrollo de los trabajos técnicos, la toma de decisiones, las fuentes y problemas de la financiación y los diferentes criterios que rigieron la actuación. Además, contienen mucha información sobre el estado de las piezas y datos de gran interés para su estudio material y formal.

26 Las fechas están extraídas, obviamente, del diario publicado por Álvarez de Benito. El capítulo dedicado a la reconstrucción de la Caja de las Ágatas consta de 39 páginas tamaño A-4 a dos columnas, con 28 ilustraciones.

27 Además del testimonio de C. ÁLVAREZ DE BENITO, op. cit., 2002a, p. 399, véanse las fotos publicadas en el apéndice de reproducciones gráficas, La restauración de las joyas..., op. cit., 2002, p. 463.

28 C. ÁLVAREZ DE BENITO, op. cit., 2002a, p. 400: “creo que fue la única parte de la pieza que no sufrió deterioro. Sólo hubo que poner unos pequeños clavitos de plata que se habían desprendido". 
dobladas, desgarradas y rotas habían sufrido especialmente debido a la técnica de repujado con que habían sido labradas, en especial el panel superior trasero, completamente plegado y doblado (Fig. 1). El trabajo se inició por los paneles superiores de la tapa, siguió por los inferiores de esta, a continuación se trabajó sobre los de la parte inferior de la caja, y se remató la labor en las tiras de las limatesas del pabellón de la tapa y las cantoneras. En la primera fase de la tarea, de estiramiento y desdoblamiento, se adoptó el criterio de mínima intervención, sin aplicar puntos de soldadura entre fragmentos. Se utilizó este procedimiento en algunos fragmentos de las tiras de las limatesas y cantoneras, donde los desgarros y pliegues amenazaban con rotura inmediata. El tratamiento aplicado al armazón de madera consistió en extraer los 105 clavos de sujeción de las placas de oro, que habían quedado incrustado tras el violento despojo de estas, la toma de una muestra para análisis botánico, procedente de la esquina superior izquierda del larguero frontal de la tapa, donde se apreciaban huellas de combustión y faltaba una de las láminas de ágata. Extraído el trozo, fue rellenado el hueco con un fragmento igualmente de ciprés ${ }^{29}$.

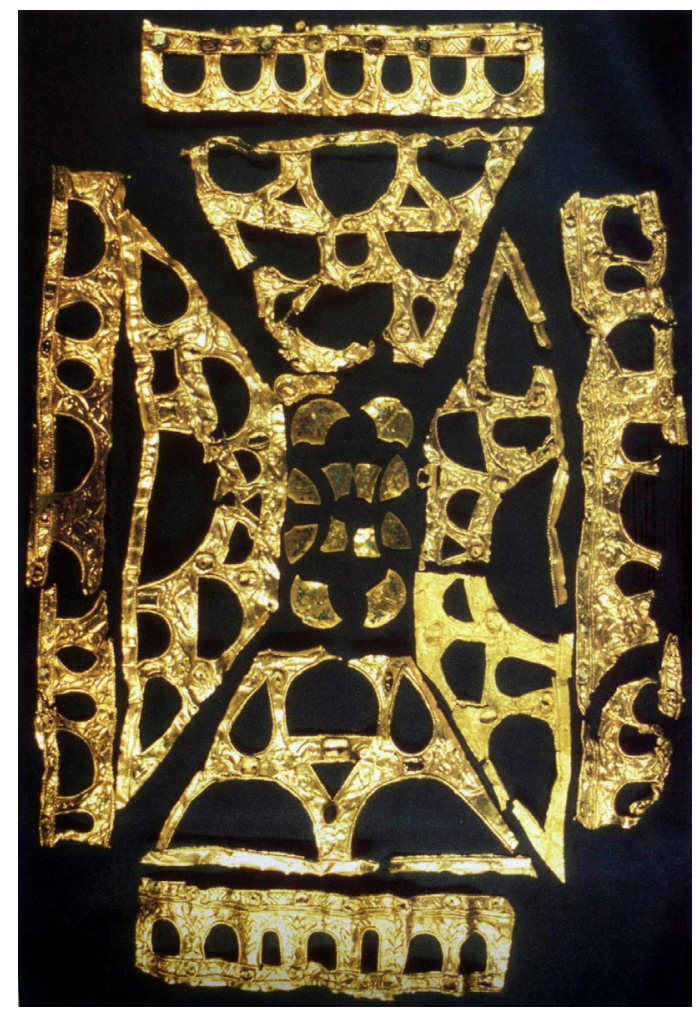

Fig. 1. Estado de la Arqueta de las Ágatas tras la destrucción de 1977. Foto: C. Álvarez de Benito.

29 C. ÁlVAREZ DE BENITO, op. cit., 2002a, pp. 426-428. 
La Comisión se pronunció específicamente sobre la arqueta por vez primera en su sesión de 11 de abril de 1984. El restaurador solicitó respuesta a diversas cuestiones relativas a la posibilidad de soldar los componentes por las líneas de rotura, la reintegración de lagunas, la sustitución de cantoneras adventicias de plata, el refuerzo de los chatones, la decisión sobre la placa franca -perdida a la sazón-, la reproducción del repujado en los paños donde se hubiera perdido, la reposición de las láminas perdidas de ágata y los criterios para el tratamiento de la pedrería ${ }^{30}$. La Comisión acordó autorizar la soldadura, no cubrir las lagunas de material, mantener las cantoneras de plata existentes, reforzar los chatones, restablecer el cincelado "en las partes en que está totalmente perdido y no actuar en las partes en que esté medianamente perceptible". Sobre el equipamiento de pedrería, estableció "poner una ágata lisa en los huecos de las tres que faltan para taparlos, realizando una inscripción del año. Respecto a las dos ágatas a las que les falta un trozo, se acuerda colocar un trozo en la que le falta la mayor parte y no añadir material alguno en la otra a la que solamente le falta un trozo pequeño". En lo referente a la pedrería, acordó

"reponer las piedras originales y desechar las añadidas en la restauración de 1942; incorporar las piedras dudosas pero de evidente antigüedad; para el resto, aplicar los criterios que se tuvieron en cuenta para la Cruz de la Victoria" y "poner todas las piedras que faltaban antes del expolio" ${ }^{31}$.

Conforme estas instrucciones, se procedió a repujar solamente "en los paneles superiores y en algunas cantoneras, quedando sin tocar las partes principales del frente, trasera y laterales", con el concurso de un especialista ${ }^{32}$. La colocación de los paneles de oro sobre el armazón de madera, tras igualar la coloración, se hizo clavándolos a la madera bajo los engastes ${ }^{33}$. A continuación, entre mayo y junio de 1985 se engastaron las 224 piedras, de las cuales 152 habían sido recuperadas -88 posibles originales o antiguas y 64 no originales, modernas-, siendo las 72 restantes de nueva aportación. Diferenciadas las piedras a recolocar, y obtenidas las nuevas, se procedió a engastar las piezas, conforme los siguientes criterios. Las posibles originales, cuyos engastes fueron identificados en la documentación disponible, fueron reintegrados a su lugar.

"El resto de las posibles originales se distribuyen con un criterio estético en sus encajes naturales. Las gemas nuevas se distribuyen atendiendo en lo posible a la única referencia en color de 1942, aunque esta estaba hecha de una manera arbitraria. La distribución en proporción del tipo de piedra, se hace según la proporción de las posibles orinales (sic) recuperadas" ${ }^{34}$.

30 La restauración de las joyas..., op. cit., 2002, pp. 287-288.

31 Ibid., pp. 109-111.

32 Ibid., p. 465, ofrece dibujo donde se indican las partes retocadas del repujado.

33 C. ÁlVAREZ DE BENITO, op. cit., 2002a, p. 403.

34 C. ÁLVAREZ DE BENITO, op. cit., 2002a, p. 416. En las pp. 418-424 se ofrece la lista completa de las 225 piedras incorporadas a la reconstrucción con dibujo de su ubicación en p. 421. En la lista falta la piedra $\mathrm{n}^{\circ} 150$. El cómputo de engastes de la arqueta es, por tanto, de 224 . La ausencia de piedra en el $\mathrm{n}^{\circ} 150$ puede deberse a la necesidad de corregir un error inicial de cuenta, una vez que ya se habían realizado los análisis identificativos de cada uno de los elementos, evitando tener que renumerar desde el inicio, operación 
La placa franca fue encontrada fragmentada en cuatro trozos, a añadir al único fragmento encontrado en 1977 -correspondiente al engaste de la esquina izquierda inferior de la orla que rodea a los esmaltes- y a las doce plaquitas de estos ${ }^{35}$. Había perdido casi todos los rellenos rojos de las celdillas de las orlas tanto del borde como de la superficie superior. La primera actuación se limitó a estirar, desdoblar y planchar los trozos. Se pudo apreciar que el destrozo había implicado la rotura de los fondos de los engastes y numerosos pinchazos por la superficie -probablemente aplicados para extraer las piedras-. Un cuestionario sobre los criterios y procedimientos técnicos a emplear en las fases sucesivas fue remitido a la Comisión el 4 de mayo de $1990^{36}$. Esta acordó en sesión de 15 de octubre de 1990, aceptar las soluciones técnicas propuestas por el orfebre, consistentes en soldar y unir con puentes, inspirándose en la propia técnica de confección de la pieza. Se acordó igualmente reforzar la base de los chatones con tiras de lámina de oro dispuestas en $\mathrm{H}$ o X, reforzar la placa con una lámina inferior, no reponer las pequeñas lagunas del revestimiento metálico, reconstruir las faltas de las bandas de celdillas, solución imprescindible para garantizar la estabilidad del resultado final, y posponer la decisión sobre la reintegración total de los cristales rojos de estas bandas ${ }^{37}$.

La placa en su conjunto fue colocada con garras sobre una lámina de oro a la que se soldaron las cuatro patas de fijación a la madera. Como resultado tanto de las roturas padecidas, como de los necesarios ajustes y aportes de nuevos materiales, el bastidor sufrió una cierta distorsión que impedía el perfecto encaje de las plaquitas esmaltadas. Sometido el problema a la consideración de la Comisión, esta, en sesión de 2 de diciembre de 1991, acordó aceptar la solución propuesta por el técnico restaurador, consistente en suplementar los esmaltes por la base con sendas laminillas de plata y oro, e insertarlos a su vez en unas celdillas ajustadas exactamente a los perímetros deformados de sus encastres originales, de forma que se garantizara su sujeción, siendo procedimiento completamente reversible, pues los esmaltes quedarían fijados a la placa por simple ajuste y presión física.

Restaba tomar la decisión sobre la reintegración o no de las celdillas de las bandas rojas de la placa. Observada la placa con el conjunto de cristales originales conservado, apenas un $10 \%$, se decidió "dejar los cristales originales recuperados concentrados en lo posible en una zona de la pieza, reponiendo los cristales en las celdillas que faltan" ${ }^{38}$. El procedimiento de fabricación de estos fue muy laborioso, pues requirió la obtención de un molde exacto para cada celdilla, mediante incrustación por presión de una finísima lámina de oro puro de $0,2 \mathrm{~mm}$, que fue el rellenado con la pasta vítrea

considerablemente engorrosa. La misma lista permite verificar que el número de piedras repuestas en 1986 fue de 136, es decir, se completaron los 72 engastes vacíos y se sustituyeron las 64 piedras modernas o sin valor que la caja contenía antes de 1977.

35 C. ÁlVVAREZ DE BENITO, op. cit., 2002a, p. 429, foto en p. 436 (esmaltes); R. PLATERO FERNÁNDEZ-CANDAOSA, op. cit., 2002, foto en p. 255 (esmaltes y fragmento recuperado en 1977).

36 La restauración de las joyas..., op. cit., 2002, p. 297.

37 Ibid., pp. 141-143; R. PLATERO FERNÁNDEZ-CANDAOSA, op. cit., 2002, pp. 267-268.

38 La restauración de las joyas..., op. cit., 2002, p. 145; R. PLATERO FERNÁNDEZ-CANDAOSA, op. cit., 2002, p. 268. 
y esmaltado, colocándose después uno a uno los pequeños vidrios en cada celdilla ${ }^{39}$. Por último, sobre la pedrería de la placa, una delegación de la Comisión resolvió en reunión mantenida con el orfebre el 21 de mayo de 1993, que se colocasen las dos piedras recuperadas y se repusiesen las siete perdidas. Ejecutado este encargo, la placa fue reintegrada a la Arqueta de las Ágatas en el otoño del mismo año ${ }^{40}$.

\section{Descripción material}

\subsection{La construcción del armazón de madera}

La Arqueta de las Ágatas es una caja de madera recubierta por láminas de oro repujado que soportan engastes de pedrería. La documentación obtenida en el momento de la restauración tras 1977, cuando el despojo del revestimiento metálico dejó a la plena observación el mueble, permite superar las fotografías deficientemente publicadas del exterior del mismo, de tan escaso tamaño y resolución que apenas permiten apreciar algún rasgo ${ }^{41}$. La caja está constituida por dos piezas macizas, caja y tapa, labradas por recorte y talla por el exterior y vaciado por el interior en sendos bloques de ciprés. Este procedimiento la singulariza en el panorama de arquetas y cajas conservadas, donde la norma es la construcción mediante ensamble de paneles y largueros, y la emparenta estrechamente con la Arqueta de San Genadio de la catedral de Astorga, donde se ha podido documentar la misma labor ${ }^{42}$. Esta técnica explica parcialmente las dimensiones achatadas de su volumen, que se diferencia notablemente de las proporciones mucho más tendentes al cubo de las restantes piezas de formato comparable.

Las fluctuaciones en las medidas pueden depender de la toma en consideración de los engastes y los cabujones o no. Las medidas consensuadas en la longitud, 42,5 $\mathrm{cm}$, y anchura, $27 \mathrm{~cm}$, aumentan ligeramente si se tienen en cuenta estos cabujones, hasta 43,5 y $27,3 \mathrm{~cm}$ respectivamente. La altura completa es de $19,6 \mathrm{~cm}^{43}$. Hasta las esquinas exteriores del prisma es de $11 \mathrm{~cm}(5,8 \mathrm{~cm}$ de la caja y $5,2 \mathrm{~cm}$ de la tapa). Las hemiesferas aplicadas como pies a la base miden $2 \mathrm{~cm}$ de altura. El receptáculo interior de la caja mide $38,4 \times 23,3 \mathrm{~cm}$ y $3,6 \mathrm{~cm}$ de profundidad, a los que se suman los $3 \mathrm{~cm}$ de profundidad de la tapa. El grosor de la madera es de $2 \mathrm{~cm}$ en caja y tapa. Se configura por tanto un contenedor interior de 38,4 x 23,3 x 6,6 cm. En la actualidad la caja está forrada con fragmentos de un tejido amarillo sujeto con clavos al armazón.

39 C. ÁlVAREZ DE BENITO, op. cit., 2002a, p. 433.

40 La restauración de las joyas..., op. cit., 2002, p. 148; R. PLATERO FERNÁNDEZ-CANDAOSA, op. cit., 2002, p. 269.

41 La restauración de las joyas..., op. cit., 2002, p. 463. Gracias a D. Carlos Álvarez de Benito he podido acceder a las diapositivas originales.

42 J.L. ALONSO BENITO, “Arqueta de Alfonso III o de San Genadio", Catálogo de obras restauradas 2003-2007. Centro de Conservación y restauración de Bienes Culturales de Castilla y León, Valladolid 2008, pp. 356-361, esp. p. 360 .

43 La diferencia con las medidas precedentemente publicadas se debe al nuevo sistema de sujeción de la placa franca, que realza su colocación. 
En la tapa el forro consta de cinco trozos, adaptados a los cuatro paneles trapeciales y al rectángulo central. En la caja, de otros cinco, correspondientes a los cuatro paneles $\mathrm{y}$ al fondo rectangular.

Se posee referencia detallada del peso, obtenido por Joaquín Manzanares en 1970: $7420 \mathrm{gr}^{44}$. Carlos Álvarez de Benito proporciona una detallada tabla de los pesos del revestimiento de oro al final de la restauración, con un total de 1306,07 gr, de los que 21,18 son de nuevo aporte, a los que se añaden 13,51 gr de plata correspondientes a las tiras cantoneras frontal izquierda y las dos traseras, y los 211,40 gr de la placa franca ${ }^{45}$. Los pesos de la pedrería reintegrada se pueden obtener de la relación individual de las 224 piedras insertadas en la restauración, incluidas las de la placa franca, que se incluye en la tabla confeccionada por Carlos Álvarez y Dámaso Moreiras ${ }^{46}$ : la suma arroja un total de 571,72 qm, equivalentes a 114,34 gr ( $0,20 \mathrm{gr} / \mathrm{qm})$. Los esmaltes de la placa superior han sido pesados por Álvarez de Benito, resultando un total de 41,95 gr. En total, pues, resultan 1687,41 gr de revestimiento orfebrístico, a lo que habría que sumar el peso de las láminas de ágata, del que solamente consta el de las cuatro repuestas, de $25,05,47,65,62,13$ y 79,64 gr respectivamente. ${ }^{47}$ Sabiendo que existen 99 placas, puede estimarse para ellas en su conjunto un peso no superior a 800 gr, lo que permite calcular que el peso del armazón de madera supera los $5 \mathrm{kgs}$. Es patente que se trata de un objeto recio, concebido para albergar y soportar otro objeto u objetos pesados, y enormemente sólido, al carecer de cualquier punto de debilidad.

El diseño de la arqueta consiste en una caja prismática rectangular, que ofrece cuatro largueros y un panel inferior, y una tapa constituida por cuatro largueros formando rectángulo, de las mismas dimensiones que los de la caja, y un pabellón apoyado en ángulo agudo sobre ellos, configurado por cuatro paneles trapeciales y un panel rectangular que constituye el plano superior de todo el conjunto. Es por tanto un caso típico de caja prismática con tapa en pabellón o pirámide truncada. En la descripción nos atendremos siempre a la visión frontal de la arqueta, denominado delantera a la fachada de apertura, trasera a la opuesta, donde se encuentran las bisagras, lateral izquierdo y lateral derecho según el espectador. Pese a que tapa y caja están labradas en bloques únicos, mantendremos la división en largueros y paneles a fin de describir homogéneamente el aspecto de armazón y revestimiento.

En todos los largueros y en los paneles de la tapa se han recortado y vaciado los encajes para la inserción de las láminas de ágata. Todos mantienen grosso modo la misma altura y separación entre sí. No conocemos su profundidad, aunque puede su-

44 J. MANZANARES RODRÍGUEZ, op. cit., 1972, p. 18.

45 C. ÁlVAREZ DE BENITO, op. cit., 2002a, pp. 400-401. No obstante, este peso de la placa franca corresponde al de la pieza reconstruida (204,60 gr.) antes de recuperarse la original más los 6,80 gr. del fragmento original conservado en 1977. Los trozos de esta, tal y como llegaron al taller en 1990, pesaban respectivamente $81,46,29,63,21,00$ y 5,78 gr. Con el original ya existente estas medidas arrojan un peso total de 144,67 gr. Los 66,73 gr. de diferencia constituyen una masa muy superior a la que hay que suponer añadida en la restauración por razones de estabilidad estructural y reintegración imprescindible de lagunas, y se deben a la lámina colocada bajo la original para efectuar sobre ella las soldaduras de las patas de encastre en el armazón de madera y a las propias patas. Ibid., p. 432; La restauración de las joyas..., op. cit., 2002 , p. 296: carta de C. Álvarez de Benito a Ramón Platero, 20 de noviembre de 1989.

46 C. ÁLVAREZ DE BENITO, op. cit., 2002a, pp. 418-424.

47 Ibid., p. 401. 
ponerse que no superan los $3 \mathrm{~mm}$ que han sido publicados como grosor de las láminas de ágata ${ }^{48}$. Su distribución puede establecerse a partir de las fotografías publicadas por Álvarez de Benito. Es la siguiente:

1. Caja, larguero delantero: seis encastres. Su contorno, de izquierda a derecha es como sigue: rectangular horizontal con remate superior en doble arco; rectangular horizontal; rectangular vertical; rectangular vertical; rectangular horizontal; rectangular horizontal. Las dimensiones de los encajes horizontales son idénticas, así como las de los verticales. Existe pues una verdadera intención de observar perfecta simetría en el diseño, según el ritmo $\mathrm{RH}+\mathrm{RH}+\mathrm{RV}+\mathrm{RV}+\mathrm{RH}+\mathrm{RH}$.

2. Caja, larguero trasero: seis encastres y dos más para las bisagras. Rectangular horizontal; rectangular horizontal; bisagra izquierda; rectangular horizontal; rectangular horizontal; bisagra derecha; rectangular vertical; rectangular horizontal. Todas las dimensiones de los encastres son en este caso diferentes, estando determinadas por las inserción de las bisagras. Estas unen solidariamente los largueros traseros de tapa y caja. Son originales, como lo prueba el hecho de que sus cajeados son previos a la labra de los vaciados para encajar las placas de ágata, siendo estos los que se adaptan a su presencia, simétricamente dispuesta entre los vaciados y prevista desde el diseño inicial del mueble. El ritmo es $\mathrm{RH}+\mathrm{RH}+\mathrm{Bi}+\mathrm{RH}+\mathrm{RH}+\mathrm{Bi}+\mathrm{RV}+\mathrm{RH}$.

3. Caja, larguero lateral izquierdo: cinco encastres. Semicircular; rectangular vertical; semicircular; rectangular vertical; semicircular. Las dimensiones de vaciados semicirculares y verticales son idénticas entre sí. Se adopta un ritmo perfectamente simétrico $\mathrm{S}+\mathrm{RV}+\mathrm{S}+\mathrm{RV}+\mathrm{S}$.

4. Caja, larguero lateral derecho: cinco encastres. Semicircular; rectangular vertical con remate en arco; semicircular; rectangular vertical con remate en arco; semicircular. Igualmente, las dimensiones de los dos tipos de vaciados son idénticas entre sí. Se adopta un ritmo perfectamente simétrico $\mathrm{S}+\mathrm{RA}+\mathrm{S}+\mathrm{RA}+\mathrm{S}$.

5. Tapa, larguero delantero: nueve encastres. Rectangular vertical con remate en arco; semicircular; rectangular vertical con remate en arco; elíptico vertical; semicircular; semicircular; elíptico vertical; rectangular vertical con remate en arco; semicircular. Se aprecia igualmente una plena ordenación simétrica, si se prescinde del primer encastre: $(\mathrm{RA})+\mathrm{S}+\mathrm{RA}+\mathrm{EV}+\mathrm{S}+\mathrm{S}+\mathrm{EV}+\mathrm{RA}+\mathrm{S}$.

6. Tapa, larguero trasero: nueve encastres. Semicircular; rectangular vertical con remate en arco; semicircular; rectangular vertical con remate en arco; semicircular; rectangular vertical con remate en arco; semicircular; rectangular vertical con remate en arco; semicircular. Ritmo perfectamente definido con alternancia e inversión de los miembros si se toman los miembros de tres en tres, intención perfectamente lograda al estar separados los trimembres por las bisagras: $\mathrm{S}+\mathrm{RA}+\mathrm{S}+\mathrm{RA}+\mathrm{S}+\mathrm{RA}+\mathrm{S}+$ $\mathrm{RA}+\mathrm{S}$.

7. Tapa, larguero izquierdo: siete encastres. Rectangular vertical con remate en arco; semicircular; rectangular vertical; subrectangular horizontal; rectangular vertical; subcuadrado; rectangular vertical con remate de arco. Aunque los contornos son cierta-

48 C. CID PRIEGO, op. cit. (1995-1996), p. 28. 
mente irregulares, el ritmo es perfectamente perceptible: $\mathrm{RA}+\mathrm{S}+\mathrm{RV}+\mathrm{RH}+\mathrm{RV}+$ $\mathrm{C}+\mathrm{RA}$.

8. Tapa, larguero derecho: siete encastres. Subcuadrado; rectangular vertical con remate en arco; rectangular vertical con remate en arco; subcuadrado; rectangular vertical con remate en arco; rectangular vertical con remate en arco; semicircular. Clara voluntad rítmica, aun con problemas de contorno: $\mathrm{C}+\mathrm{RA}+\mathrm{RA}+\mathrm{C}+\mathrm{RA}+\mathrm{RA}+\mathrm{S}$.

9. Tapa, panel delantero: diez encastres. Al cambiar el diseño de la superficie, trapecial, la distribución y el contorno de los encastres se organiza radialmente en dos coronas a partir de la gran pieza central de la base, semicircular. A su lado se colocan, a izquierda y derecha, dos encastres intermedios semicirculares y dos extremos en forma de lágrima, perfectamente adaptados al ángulo. En la mitad superior y menor del trapecio se colocan dos semicírculos en los extremos, adaptados a las enjutas de la pieza central, otros dos semicírculos inclinados tangentes a la curva de la pieza central y un pequeño sector circular encajado en el ápice de la composición. El ritmo definido en la mitad inferior es $\mathrm{L}+\mathrm{S}+\mathrm{S}+\mathrm{S}+\mathrm{L}$. En la superior, $\mathrm{S}+\mathrm{S}+\mathrm{s}+\mathrm{S}+\mathrm{S}$.

10. Tapa, panel trasero: diez encastres. Distribución muy semejante a la del panel delantero, cambiando los semicírculos intermedios de la base por trapecios de remate en arco. El ritmo definido en la mitad inferior es $\mathrm{L}+\mathrm{TA}+\mathrm{S}+\mathrm{TA}+\mathrm{L}$. En la superior, $\mathrm{S}+\mathrm{S}+\mathrm{s}+\mathrm{S}+\mathrm{S}$.

11. Tapa, panel lateral izquierdo: seis encastres. Dos grandes semicírculos en la mitad inferior, un gran semicírculo flanqueado por tres triángulos en la superior. El ritmo buscado entrecruza dos triángulos, formado el mayor por los tres semicírculos y el menor, invertido, por los tres triángulos.

12. Tapa, panel lateral derecho: once encastres. Composición compleja, organizada en tres niveles. Tres semicírculos en el inferior, con tres triángulos en las enjutas; dos semicírculos con cuadrado entre ambos, en el central; un semicírculo flanqueado por dos triángulos en el superior. A su vez, los cuatro semicírculos centrales con el cuadrado interior configuran una cruz, superpuesta al aspa conformada por los cuatro triángulos y el mismo cuadrado que actúa como eje de la composición. Por último, los seis semicírculos se ordenan piramidalmente en un triángulo.

En el panel superior de la tapa se ha labrado por vaciado una cruz patada de brazos iguales con medallón central. No se conoce la profundidad de este cajeado. En los cuatro campos situados junto a los brazos se encuentran los taladros destinados a albergar los vástagos o patas de unión con la placa superior. El hecho de que haya sido insculpida en el panel superior esta cruz griega fuerza a concebirla como un juego de encastres originalmente diseñado para cerrar la composición, el cual, por razones que desconoceremos siempre, fue desechado y sustituido por la inserción de la placa de orfebrería franca, de dominante igualmente cruciforme.

En total, pues, se han labrado 91 encastres, 92 si se cuenta la cruz patada del panel superior de la tapa. La distribución de láminas de ágata en los largueros rectangulares de tapa y caja está regida por el principio de asignar 12 piezas a cada lateral de la arqueta $(5+7)$, y 15 al frontal y al trasero $(6+9)$, en total 54 láminas. El número corresponde a la suma de 12 Profetas, 12 Apóstoles, y los presentes en la visión de la corte de Dios -24 Ancianos, 4 Vivientes, ángel y Juan-(Ap, 4,4-5,4). Aun cuando no 
conozco texto que justifique esta elección, la coincidencia no parece casual, máxime cuando las láminas se disponen en el plano inferior de la arqueta, soportando la tapa, presidida por una composición cruciforme claramente escatológica.

Con la restauración pudo apreciarse con claridad la inexistencia de un cierre en el diseño original ${ }^{49}$. Esta circunstancia puede deberse a dos factores. Por un lado, el perfecto ajuste de la tapa y la caja, conseguido por la carencia de ensambles y el peso de la tapa, lo que garantiza un cierre seguro. Por otro, la necesidad de facilitar la apertura frecuente de la arqueta. Si este fuera el caso, la arqueta habría sido destinada a acoger objetos de utilización cotidiana, probablemente diaria, y no a ser depósito de bienes permanentemente ocultos ${ }^{50}$.

En la arqueta astorgana, la ya citada restauración permitió descubrir que el larguero posterior de la caja conservaba los encastres de las bisagras originales, desaparecidas, que se encontraban rehundidas para permitir "el acomodo de las planchas metálicas". También se puso al descubierto "el dibujo preparatorio inciso en la madera correspondiente a la localización de las arcadas presentes en las planchas metálicas". ${ }^{51}$ Los cajeados de las bisagras son de menor tamaño que los de la caja ovetense.

\subsection{El recubrimiento metálico de laterales y tapa}

Cada uno de los largueros y paneles de caja y tapa está revestido por una lámina de oro de 18,69 quilates $^{52}$. Estas doce láminas metálicas están caladas para dejar ver las ágatas subyacentes. Presentamos a renglón seguido la disposición de cada una de ellas, a fin de poder comparar entre el proyecto de encastre de ágatas y el proyecto de revestimiento metálico.

1. Caja, larguero delantero (Fig. 2): diez huecos, todos ellos rectangulares verticales rematados en arco (RA). Su anchura es uniforme en las cuatro parejas exteriores, y menor en la central. Los campos metálicos entre las cuatro parejas de los extremos son mucho más estrechos que los que los separan entre sí. Por el contrario, la pareja central, de arcos estrechos, está separada por un campo metálico de igual anchura que los que la separan de las parejas adyacentes.

2. Caja, larguero trasero (Fig. 3): diez huecos, todos ellos rectangulares verticales rematados en arco (RA). Las dimensiones difieren, distinguiéndose tres tipos. De izquierda a derecha, se ordenan así: estrecho; estrecho; mediano; mediano; mediano, mediano; ancho; estrecho; ancho; ancho. Las parejas primera y quinta -las de ambos extremos- están separadas por campos metálicos estrechos. Las parejas segunda y tercera están separadas por campos medianos. Los restantes huecos están divididos por

49 La restauración de las joyas..., op. cit., 2002, p. 118; C. ÁLVAREZ DE BENITO, op. cit., 2002a, pp. 400-401 y p. 403 .

50 Nuevamente, la caja de Astorga se manifiesta como paralelo técnico: en la restauración de 2005-2006 le fue retirado el cierre postizo del s. XVIII, pudiendo apreciarse que no contó con él en el diseño original. $C f$. J.L. ALONSO BENITO, op. cit., 2008, p. 361.

51 Ibid., p. 360.

52 C. ÁlVAREZ DE BENITO, op. cit., 2002a, p. 400. 


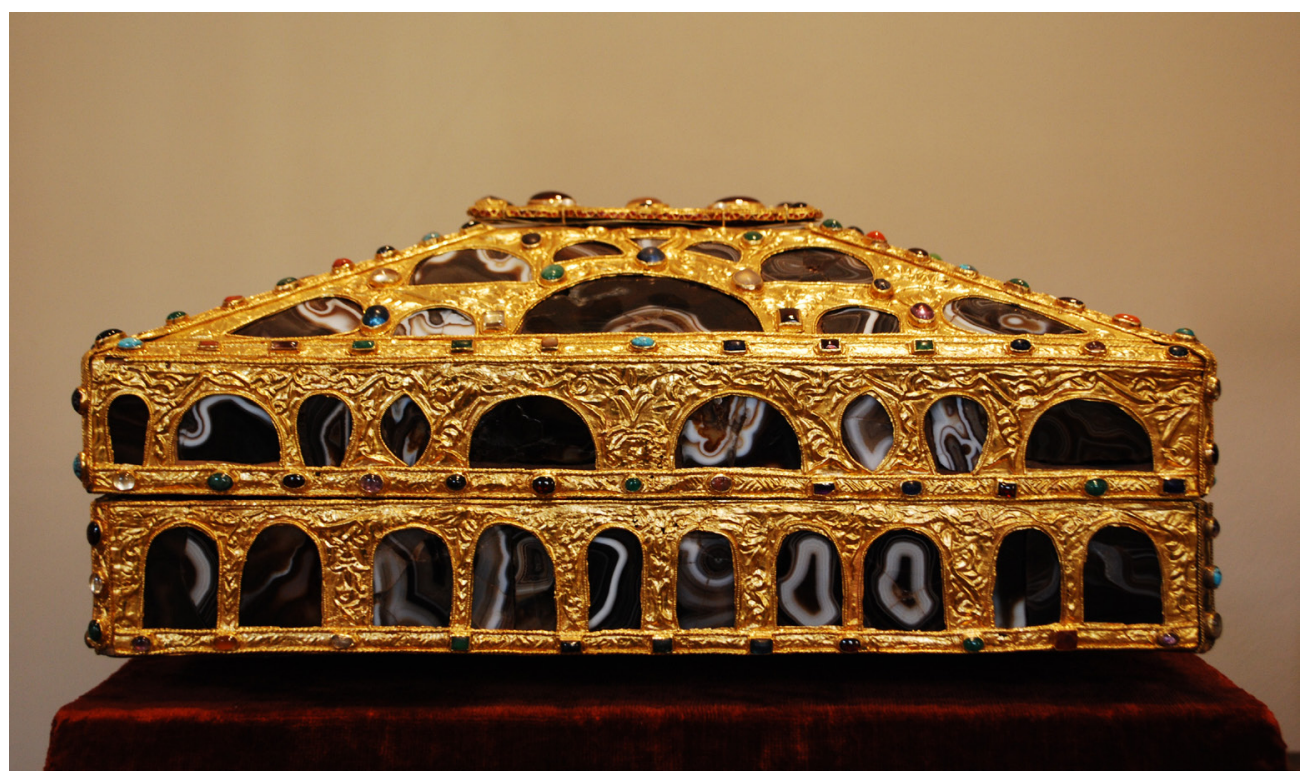

Fig. 2. Arqueta de las Ágatas. Vista frontal. Foto: César García de Castro Valdés.

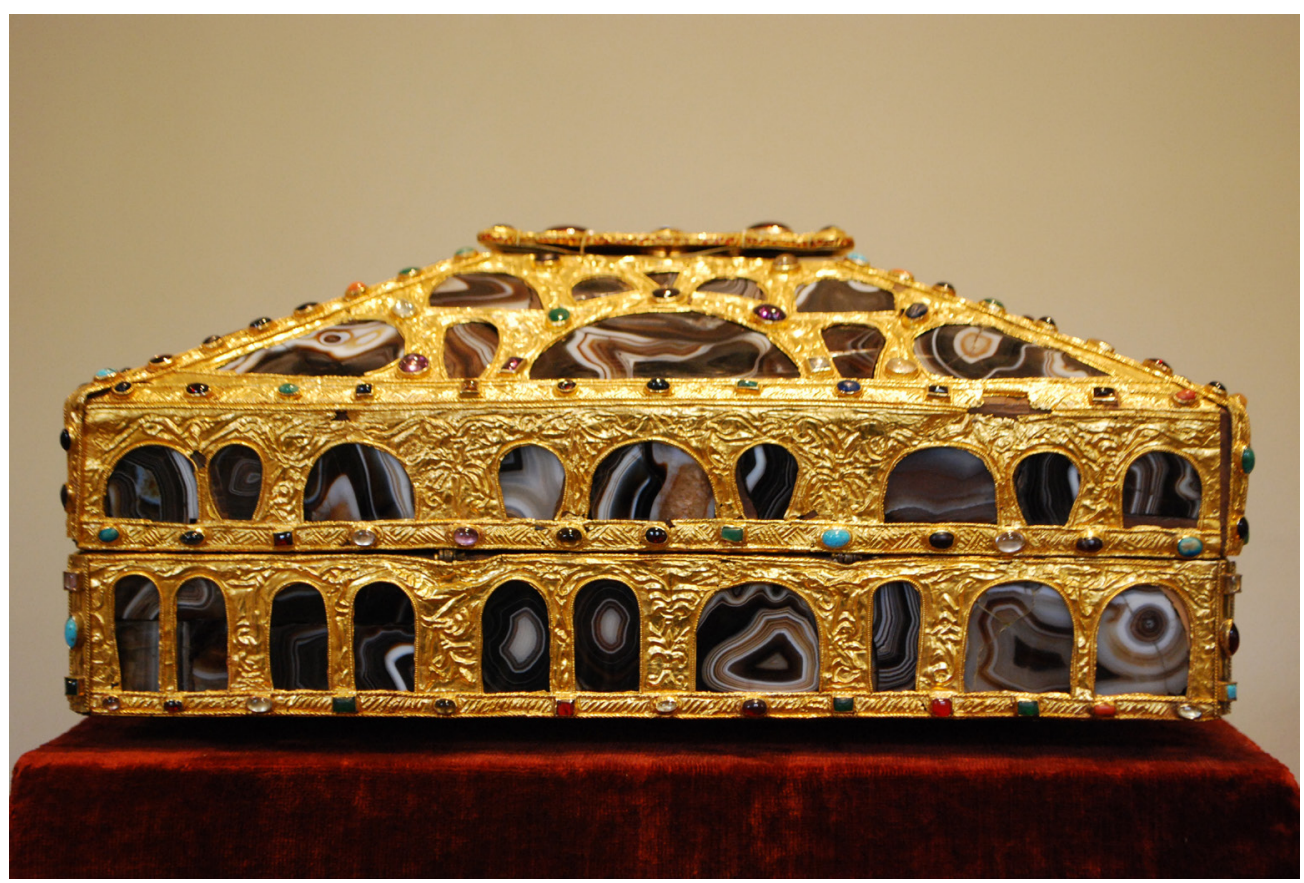

Fig. 3. Arqueta de las Ágatas. Vista posterior. Foto: César García de Castro Valdés. 


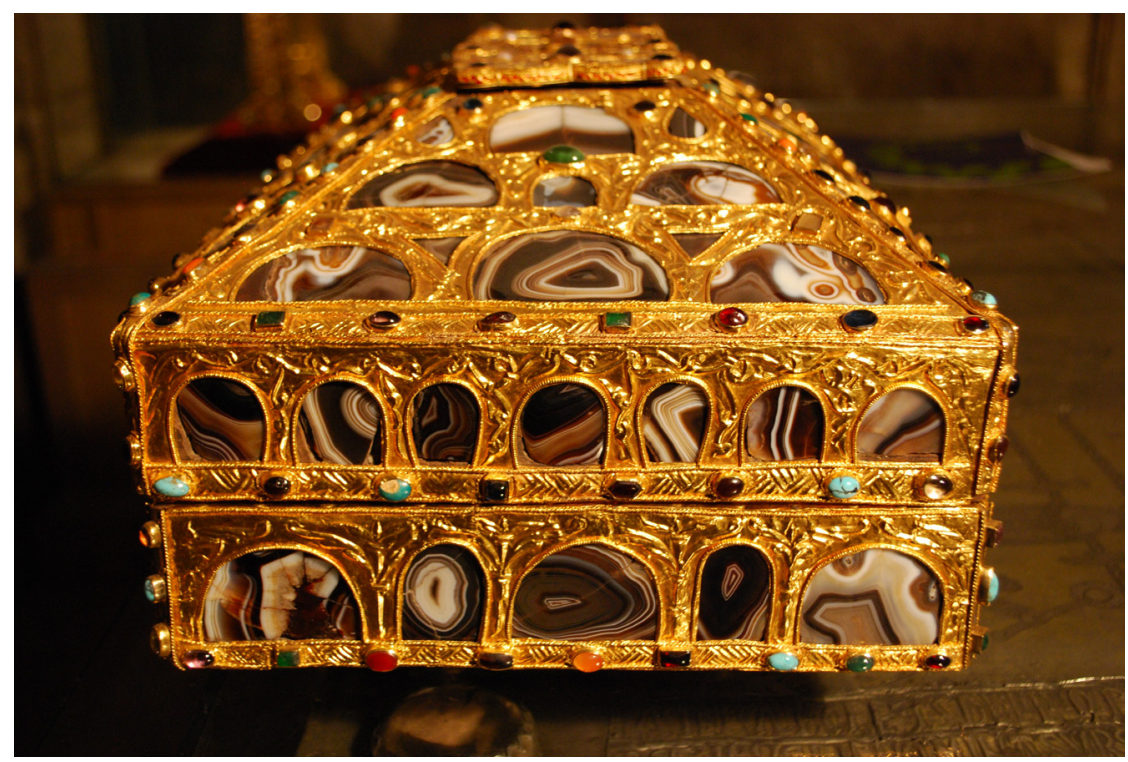

Fig. 4. Arqueta de las Ágatas. Vista lateral izquierda. Foto: César García de Castro Valdés.

campos anchos, destinados a ocultar las bisagras, dato que confirma la originalidad de estas, pues el revestimiento metálico se adapta a su contorno y relieve en ambos casos.

3. Caja, larguero lateral izquierdo (Fig. 4): cinco huecos. Se distribuyen rítmicamente según la serie $\mathrm{S}+\mathrm{RA}+\mathrm{S}+\mathrm{RA}+\mathrm{S}$.

4. Caja, larguero lateral derecho (Fig. 5): cinco huecos. Se distribuyen rítmicamente según la serie $\mathrm{S}+\mathrm{RA}+\mathrm{S}+\mathrm{RA}+\mathrm{S}$.

5. Tapa, larguero delantero: nueve huecos. Rectangular vertical rematado en arco; semicírculo; trapecial vertical rematado en arco; elíptico vertical; semicircular; semicircular; elíptico vertical; trapecial vertical rematado en arco; semicircular. Si se prescinde del hueco extremo izquierdo, la ordenación rítmica y simétrica es patente: RA + $\mathrm{S}+\mathrm{TA}+\mathrm{EV}+\mathrm{S}+\mathrm{S}+\mathrm{EV}+\mathrm{TA}+\mathrm{S}$.

6. Tapa, larguero trasero: nueve huecos. Semicírculo; trapecio vertical rematado en arco; semicírculo; trapecio vertical rematado en arco; semicírculo; trapecio vertical rematado en arco; semicírculo; trapecio vertical rematado en arco; semicírculo. El ritmo y simetría son absolutos, trimembres, estando separados con total claridad cada uno de los miembros por anchos campos metálicos, coincidentes con la posición de las bisagras: $\mathrm{S}+\mathrm{TA}+\mathrm{S}+\mathrm{TA}+\mathrm{S}+\mathrm{TA}+\mathrm{S}+\mathrm{TA}+\mathrm{S}$.

7. Tapa, larguero izquierdo: siete huecos. Semicírculo; semicírculo; rectángulo vertical rematado en arco; semicírculo; rectángulo vertical rematado en arco; semicírculo; semicírculo. Ritmo perfectamente establecido y simétrico: $\mathrm{S}+\mathrm{S}+\mathrm{RA}+\mathrm{S}+\mathrm{RA}+\mathrm{S}$ $+\mathrm{S}$. 


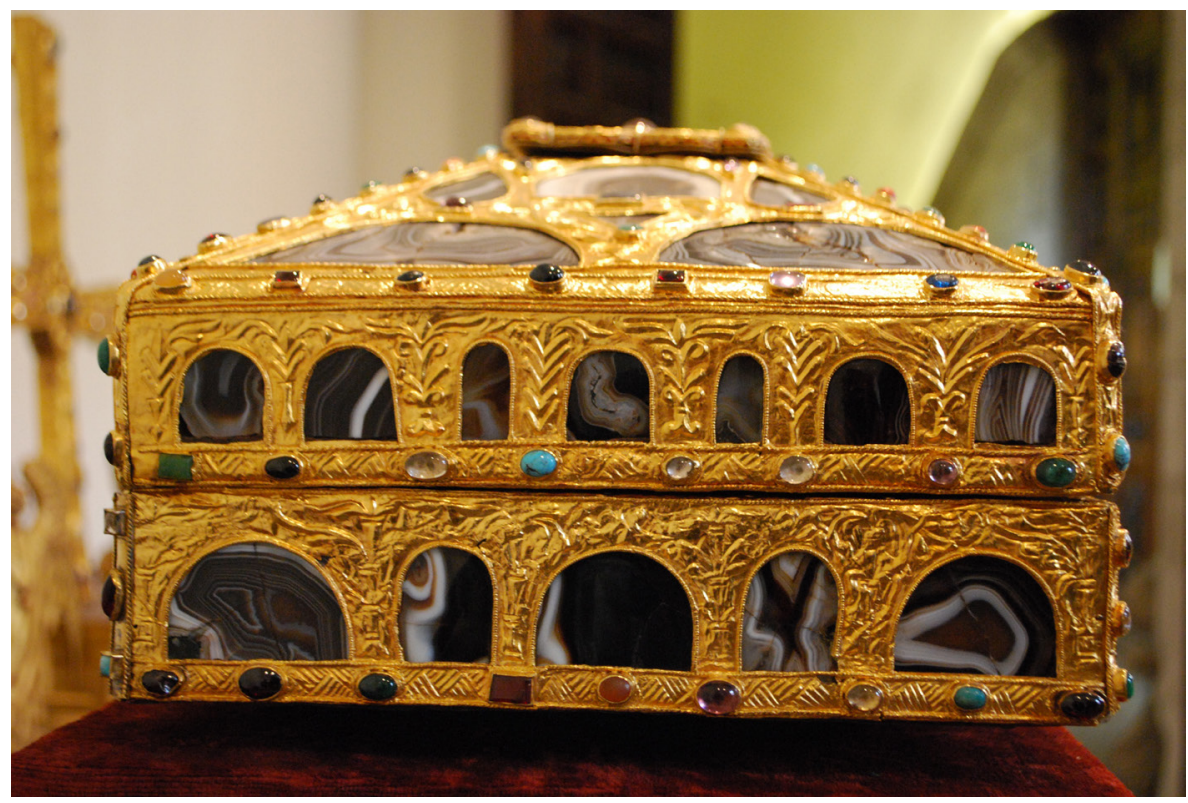

Fig. 5. Arqueta de las Ágatas. Vista lateral derecha. Foto: César García de Castro Valdés.

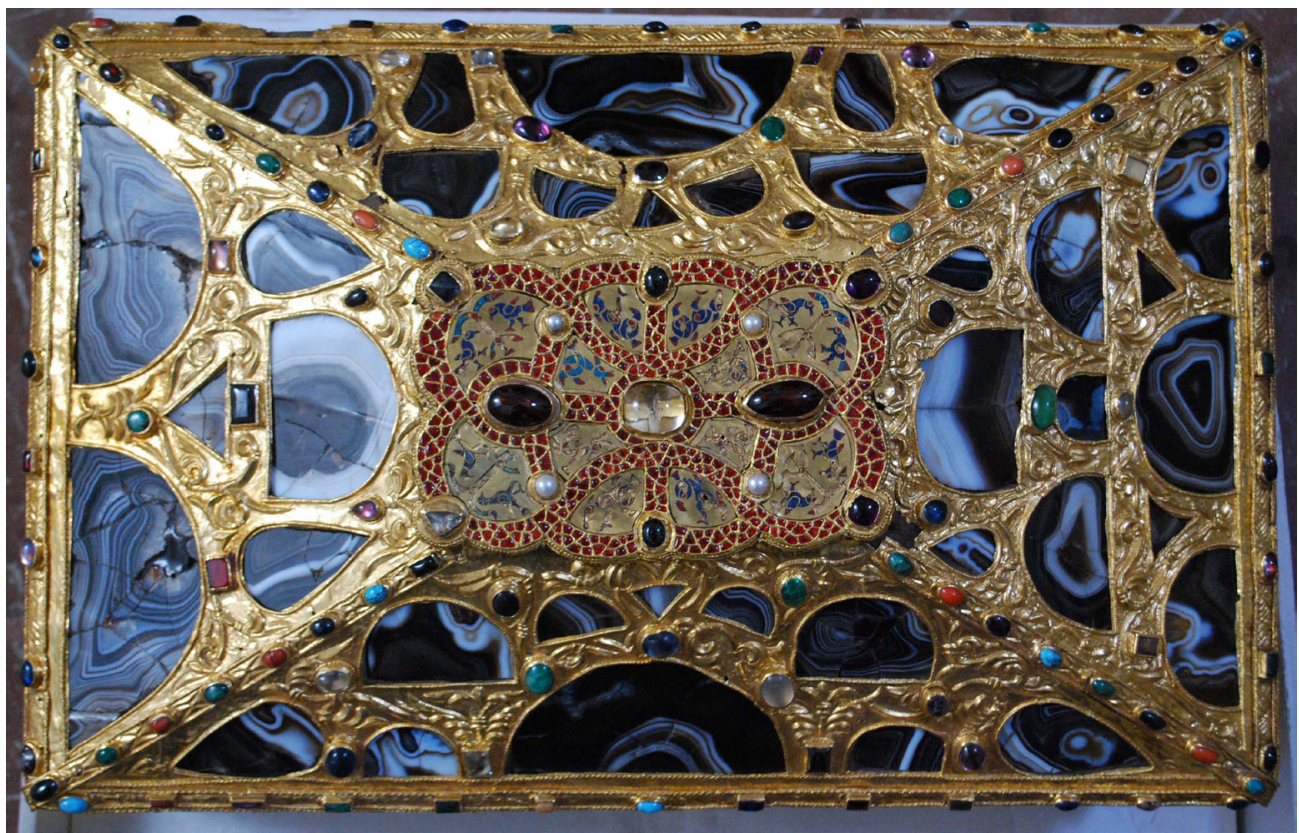

Fig. 6. Arqueta de las Ágatas. Cubierta. Foto: César García de Castro Valdés. 
8. Tapa, larguero derecho: siete huecos. Semicírculo; semicírculo; rectángulo vertical rematado en arco; semicírculo; rectángulo vertical rematado en arco; semicírculo; semicírculo. Ritmo perfectamente establecido y simétrico: $\mathrm{S}+\mathrm{S}+\mathrm{RA}+\mathrm{S}+\mathrm{RA}+\mathrm{S}$ $+\mathrm{S}$.

9. Tapa, panel delantero (Fig. 6): diez huecos. Se ajustan perfectamente a los encastres de ágatas infrayacentes.

10. Tapa, panel trasero: diez huecos. Se ajustan perfectamente a los encastres de ágatas infrayacentes.

11. Tapa, panel lateral izquierdo: seis huecos. La ordenación de los encastres de las ágatas se modifica en el diseño de los contornos. Se mantienen los dos semicírculos de la mitad inferior, y el triángulo inferior y el semicírculo central de la superior, convirtiéndose los dos triángulos laterales de la mitad superior en sendas lágrimas.

12. Tapa, panel lateral derecho: once huecos. La ordenación de los encastres de las ágatas se modifica en el diseño de los contornos. Se mantienen los tres semicírculos del nivel inferior con los triángulos de las enjutas. En el nivel intermedio, se transforma en semicírculo el cuadrado central, situado entre los dos semicírculos. Por último, en el nivel superior, los triángulos laterales se transforman en lágrimas.

Esta exposición permite apreciar las modificaciones introducidas en el diseño de la arqueta al revestirla de oro. En cuanto al número de huecos, los componentes más afectados han sido los largueros frontal y trasero de la caja, que han pasado cada uno de seis a diez huecos, por división en dos de los ocho encastres rectangulares horizontales previos. En lo referente a los contornos, todos los huecos se han transformado en vanos rectangulares rematados en arco y en los paneles de la tapa los triángulos de los niveles superiores han pasado a lágrimas. La arqueta cuenta, por tanto, con 99 huecos calados, pero no con 99 láminas de ágata, sino con 91. El principio rector mantiene 12 huecos en cada larguero lateral, pero sitúa 19 en frontal y trasero, con un total de 62 huecos. Resulta patente el abandono del proyecto numerológico inicial, en función de obtener 99 huecos en el total de la arqueta, y a su distribución en $62+37$ en caja y tapa respectivamente. El aumento pudo tener igualmente intención simbólica en el caso de la caja: el añadido de 8 huecos más pudo estar motivado por el deseo de sumar a los 54 anteriormente previstos el número de justos presentes en el Arca de Noé, 8, en una coherente continuidad con la asimilación de la arqueta al Arca del patriarca que se aprecia en otros aspectos de la confección del recipiente.

Las cuatro aristas diagonales de la tapa, las cuatro esquinas de la caja y las bandas inferiores de cada uno de los ocho paneles están cubiertas en su conjunto por dieciséis tiras de oro, donde se engasta la pedrería. Las tiras de la tapa se doblan y prosiguen por las aristas verticales que unen sus largueros.

Cada panel ha sido clavado al soporte mediante 105 clavos situados bajo los cabujones ${ }^{53}$. Las fotografías del armazón de madera permiten verificar este aserto, confirmando que las láminas de los largueros han sido fijadas a lo largo de las bandas inferiores, observándose correspondencia entre los engastes y los agujeros de los clavos.

53 Ibid., pp. 403 y 426. 
En los paneles de la tapa, los clavos figuran a lo largo de las aristas exteriores y de las aristas de unión con el plano superior. Resulta patente que la función de las tiras diagonales, las bandas inferiores y las cantoneras es reforzar las aristas del mueble, como puntos más débiles y susceptibles de levantamientos, desprendimientos y pérdidas de materia, mientras que la de la pedrería que las recubre es ocultar los clavos. El examen de la restauración permitió reconocer que las cantoneras frontal izquierda y las dos traseras eran de plata, producto de una reparación antigua ${ }^{54}$.

Se observa que el revestimiento metálico ha contribuido a reforzar la voluntad de simetría que ya destacaba de modo tan patente en el trazado de los encastres. La arqueta presenta diez huecos en los largueros frontal y trasero de la caja, y nueve en los de la tapa, cinco en los laterales de la caja y siete en los de la tapa. Suman 30 el total de los de la caja, frente a los 69 de la tapa, distribuidos en los 32 de los largueros y los 37 de los paneles. En vista cenital, los 37 encastres dibujan sin duda alguna una cruz patada, que amplifica tanto el proyecto inicial de cruz griega labrado sobre el plano superior, como la cruz que actúa como eje compositivo de la placa franca.

Todo el revestimiento metálico ha sido sometido a articulación interna y decoración. La delimitación externa de los campos decorativos se hace con líneas de cordón torso soldado. Cada uno de los calados está delimitado por líneas de hilo perlado, de menor sección. Las tiras de pedrería están igualmente delimitadas por cordón torso. Todas las superficies metálicas no caladas han sido labradas mediante repujado. En las doce tiras del prisma se aplica una muestra repetitiva de trazos oblicuos paralelos, que en la mayor parte de las bandas se compone de tramos alternantes a derecha e izquierda, dibujando triángulos, mientras que en las restantes los trazos repujados se ordenan a un solo sentido. Por el contrario, las tiras diagonales y cantoneras de la tapa están cubiertas por una sucesión de cruces patadas, diez en cada tira, que alternan con los engastes. El restaurador apreció que bajo los cabujones, en el fondo de los engastes, existía decoración repujada, de lo que, acertadamente, dedujo que "parece como si la caja no fuera a llevar piedras en estas tiras, y se tomara la decisión, después, de ponérselas" ${ }^{55}$. Ello refuerza la hipótesis expuesta líneas arriba, sobre la inicial función de la pedrería como recurso para ocultar los clavos.

La decoración de los campos planos apenas ha merecido atención por la historiografía. Se define meramente como motivos vegetales, sin que autor alguno se haya preocupado por describirlos mínimamente. La observación detallada de cada uno de las láminas permite apreciar una considerable variedad de motivos que inexcusablemente requieren presentación. Como de costumbre, procederemos ordenadamente lámina a lámina, comenzando por los largueros de la caja.

1. Caja, larguero frontal. Tallo surgente del centro del panel, ascendente hasta la banda superior y bifurcado hacia los dos extremos laterales, con trazo ondulado adaptado a los trasdoses de los huecos calados. En las enjutas se disponen semipalmetas, y hacia cada campo vertical situado entre los huecos se desprende de sucesivos cálices

54 Ibid., p. 401.

55 Ibid., p. 400. En p. 402, se inclina a considerar que el proceso de fabricación implicó labrar de corrido las tiras e insertar después los chatones soldados. 
una rama. Cada una de estas desarrolla un motivo diferente, según la superficie disponible, apreciándose cuatro tallos con semipalmetas alternantes; un tallo corto con gran semipalmeta; cuatro tallos con semipalmetas reducidas, habiéndose completado el relleno del campo mediante $\mathrm{V}$ encajadas; y una rama de la que cuelga un cáliz del que salen una flor tripétala y una semipalmeta.

2. Caja, larguero trasero. Tallo de diseño semejante al del panel frontal. El vástago vertical presenta dos series de hojitas salientes a izquierda y derecha, superpuestas en número de tres o cuatro. Los tallos descendentes a cada campo divisorio entre los calados ofrecen los siguientes motivos: seis tallos con semipalmetas alternantes; tallo con cáliz de amplios sépalos y flor tripétala, alternante con semipalmeta; colgante de vástago único rematado en botón anudado y semipalmeta vertical; el segundo campo por la izquierda ha permanecido libre de repujado por su estrechez; el cuarto campo por la izquierda presenta un tallo pendiente con dos pliegues horizontales en el extremo superior y una ondulación en el extremo inferior.

3. Caja, larguero izquierdo. Los cinco campos repiten el mismo motivo: tronco formado por tres cálices superpuestos, de los que brotan a ambos lados hojas de lóbulos largos cada vez más desarrollados, adaptándose al espacio de la enjuta correspondiente.

4. Caja, larguero derecho. Repetición del esquema del lateral izquierdo, variando exclusivamente los cálices de cada tallo, dos como máximo.

5. Tapa, larguero frontal. Tallo surgente del campo central, ondulante y con semipalmetas en las enjutas, con sendas bifurcaciones laterales, desprendiéndose ramas con dos semipalmetas alternantes descendentes hacia cada campo.

6. Tapa, larguero trasero. Dos troncos formados por pares de cálices de hojas de lóbulos alargados, surgentes en los campos intermedios, de los que brotan tallos ondulantes con semipalmetas, y ramas descolgadas con semipalmetas descendentes hacia los restantes campos. El campo extremo derecho ha quedado liso.

7. Tapa, larguero izquierdo. Siete motivos de tallos verticales, de los que surgen pares de hojas bilobuladas, que ocupan las enjutas, tangentes por sus extremos. Los troncos están formados por $\mathrm{V}$ encajadas, o por un cáliz sobre dos volutas, del que salen pares de hojas a ambos lados, que pueden superponerse en varios órdenes.

8. Tapa, larguero derecho. Dos tallos que brotan verticales de los dos campos extremos y recorren la banda superior, con semipalmetas alternantes, y ramas descendentes a cada campo con semipalmetas igualmente alternantes.

9. Tapa, panel frontal. Los espacios intersticiales entre los calados se rellenan con tallos con semipalmetas alternantes que brotan de los dos campos intermedios de la mitad inferior.

10. Tapa, panel trasero. Idéntico diseño, a partir de dos tallos situados a ambos lados del gran semicírculo de la mitad inferior.

11. Tapa, panel izquierdo. Tallos que brotan de un tronco formado por cáliz con doble voluta situado entre los dos semicírculos de la base.

12. Tapa, panel derecho. Tallos bifurcados a partir de dos troncos salientes a ambos lados del semicírculo central. 
Resulta patente que los revestimientos de los largueros laterales de la caja y el izquierdo de la tapa están regidos por una concepción mucho más arquitectónica que los restantes. La presencia de tallos individuales en cada campo intermedio refuerza su aspecto tectónico, estableciendo ejes acentuadores de la estructura vertical. En los demás largueros, por el contrario, el papel unificador de los tallos superiores destaca la componente horizontal, mediante la creación de una línea paralela a las dos bandas de pedrería. En cuanto al número de los tallos es evidente su intención simbólica: 12 en la caja $(1+1+5+5)$ y otros 12 en la tapa $(1+2+7+2)$. En los paneles de la tapa el números de tallos, $7(2+2+1+2)$, es igualmente intencional. En ambas cifras se crea la Iglesia: en las series duodecimales de Patriarcas, Profetas y Apóstoles, y en los siete diáconos (Hc. 6, 1-7), en estricta correspondencia con los dones del Espíritu. De hecho el 7 es unión de $3+4$, es decir, la Trinidad y las 4 dimensiones de la Creación, $y$, a la vez, la Trinidad y la cuatriforme palabra evangélica ${ }^{56}$.

La identificación botánica de estos tallos es problemática dadas las convenciones estilísticas y formales que presiden su diseño. No obstante, en el lateral izquierdo, los troncos con uves encajadas pueden asimilarse a palmeras, mientras que los restantes tallos con volutas o cálices superpuestos de los que brotan palmetas, presentes en los otros tres lados, pueden igualmente asignarse a tipos de la familia Arecaceae, o palmas. La elección en modo alguno es aleatoria, como aclara el Comentario al Apocalipsis de Beato (Lib. IV):

"Quod autem ait, palmae in manibus eorum (sc. sanctorum), non inmerito iustorum vita palmae comparatu: quia scilicet palma inferius tactu aspera est, et quasi aridis corticibus convoluta: superius vero et visu et fructibus pulchra: inferius corticum suarum involucionibus angustatur; sed superius amplitudine pulchrae viriditatis expanditur. Sic quippe est electorum vita, despecta inferius, superius pulchra".

Y continúa Beato señalando otra característica de la palmera: crece al revés que el resto de los árboles: estos crecen disminuyendo el tamaño conforme ascienden, mientras que la palma, por el contrario, se ensancha hacia la cima ${ }^{57}$. Por otro lado, la conformación de las semipalmetas de los roleos puede interpretarse también como semihojas de acanto, planta espinosa perenne, que gozó de un vivo resurgimiento en el s. IX debido no solamente al retorno a la iconografía grecorromana sino a la consciente implantación de los contenidos simbólicos asociados ${ }^{58}$.

56 Son abundantísimas las referencias exegéticas en la liturgia, la patrística y la teología medieval al siete y al doce. A título de ilustración recogemos esta, por la especial relación que muestra con el Evangelio: "Vere dignum: qui in omnibus sanctis caelestis Hierusalem fundamenta posuisti, quae duodecim solidata lapidibus apostolorum chorus aeclesiae tuae spiritali constructione declarat: ostendens nobis et in trinitate quadriformis euangelii constare mysterium, et in unoquoque euangeliorum trinitatis plenitudinem contineri" (Sacramentarium Veronense, 354; Edición de L.C. MOHLBERG, P. SIFFRIN y L. EIZENHÖFER, Sacramentarium Veronense, Roma, 1956, p. 48).

57 BEATO DE LIÉBANA, Comentario al Apocalipsis, J. GONZÁLEZ ECHEGARAY, A. DEL CAMPO GONZÁLEZ y L.G. FREEMAN (eds.), Obras completas de Beato de Liébana, Madrid, 1995, p. 408.

$58 C f$. E. WAMERS, "Pyxides imaginatae. Zur Ikonographie und Funktion karolingischer Silberbecher", Germania, 69.1 (1991), pp. 97-152, esp. p. 152. 
En estos cuatro paneles es evidente la superposición de la pedrería a este repujado. Igualmente, la placa franca se superpone al tallo que recorre las bandas superiores de cada uno de los cuatro paneles de la tapa. Sin embargo, los engastes de las cuatro tiras diagonales de la tapa parecen ajustarse al ritmo determinado de las cruces patadas, y lo mismo puede anotarse respecto a las bandas inferiores de los largueros de tapa y caja. Parece que el equipamiento de pedrería, surgido probablemente por la necesidad de ocultar los clavos de sujeción, se limitó en una primera instancia a resaltar las bandas y tiras de refuerzo. Una vez colocadas estas, se procedió a repartir engastes por los campos de los paneles de la tapa, disponiéndolos sobre el repujado, mientras que se mantuvieron libres de engastes los ocho largueros de tapa y caja.

\subsection{El equipamiento de pedrería}

Como acabamos de ver, la pedrería se concentra en las tiras y bandas de sujeción y en los paneles de la tapa. Álvarez de Benito identifica 225 incluyendo la placa franca ${ }^{59}$. La identificación de las 88 originales o antiguas piedras recuperadas fue realizada a instancias de Carlos Álvarez de Benito por Dámaso Moreiras y Enrique Campón, del Departamento de Cristalografía y Mineralogía de la Facultad de Geología de la Universidad de Oviedo, en informe fechado el 26 de mayo de $1986^{60}$.

La distribución de los cabujones por el contorno de la caja es la siguiente:

1. Cara frontal: 13 en la banda superior (tapa), 11 en la banda inferior (caja). 24

2. Cara trasera: 13 en la banda superior (tapa), 13 en la banda inferior (caja). 26

3. Cara izquierda: 8 en la banda superior (tapa), 9 en la banda inferior (caja). 17

4. Cara derecha: 8 en la banda superior (tapa), 9 en la banda inferior (caja). 17

El conjunto de todas las piedras de los largueros de la caja alcanza 84. La cifra responde a la suma de los 12 apóstoles y los 72 discípulos (ordo aepiscoporum + ordo presbyterorum) y, a su vez, es el producto de 7 x 12, es decir la Iglesia, que se funda sobre los 12 apóstoles asistidos por los siete dones del Espíritu Santo.

Se suman a estas 84 piedras los 12 cabujones de las cuatro cantoneras inferiores $(3 \times 4)$ y los 8 de las tiras diagonales que cubren las aristas de las esquinas de los largueros de la tapa $(2 \times 4)$. En total, la caja dispone de 50 piedras (42 en las bandas +8 de las cantoneras), y la parte inferior de la tapa de 54 (42 en las bandas +12 de las tiras diagonales). La elección de 42 piedras para cada una de las bandas de tapa y caja no parece casual: 42 es el producto de 14 x 3, es decir, las generaciones desde Abraham a Cristo, en los tres grupos en que las estableció Mateo (1, 1-17). Por otro lado, si se hace abstracción del estricto plano superior de la tapa, el prisma recipiente cuenta con 104 piedras.

59 J. MANZANARES RODRÍGUEZ, op. cit., 1972, p. 18; C. ÁLVAREZ DE BENITO, op. cit., 2002a, pp. 405-424.

60 Informe reproducido en C. ÁLVAREZ DE BENITO, op. cit., 2002a, pp. 405-416. 
La parte superior de la tapa ha recibido una dotación más rica. La banda frontal tiene 13 engastes, 12 la trasera, 8 la izquierda, 8 la derecha, y 8 cada una de las cuatro tiras diagonales (32). Por su parte, los paneles frontal y trasero poseen cada uno 11 piedras (22), y los dos laterales, 6 (12). Su distribución es grosso modo simétrica en cada panel respecto de su opuesto: de dentro afuera, 2:1:3 para los laterales, 2:5:4 para el frontal y el trasero. La placa está rodeada por tanto por tres coronas concéntricas de engastes, integradas por 8 piedras la interior, 12 la intermedia y 14 la exterior. En total, pues, el plano superior de la tapa ha recibido 107 piedras, que se suman a las 13 de la placa franca. Todo alcanza, por tanto, 120 piedras para la tapa. Ello arroja un equipamiento completo para la arqueta de 224 piedras.

Tras la serie de cómputos que antecede, incluso desde el punto de vista más escéptico es preciso reconocer que no resulta casual, posee fundamento exegético y coherencia semiótica la selección y combinación numérica de la pedrería de la arqueta.

\subsection{La placa superior}

Asumido desde el inicio de la investigación su carácter adventicio, la placa superior es la pieza que mayor interés ha suscitado y la única parte de la caja que ha merecido atención internacional (Fig. 7). Pese a ello, tampoco se ha conseguido unanimidad en las medidas publicadas. Adoptaremos aquí las establecidas por Manzanares: 151 x 97,5 x 4,6 $\mathrm{mm}^{61}$. Ante todo es preciso advertir que la altura de 4,6 $\mathrm{mm}$ se refiere al grosor total de la placa. La estructura de esta es una plancha de oro de contorno lobulado a la que se soldaron los siguientes elementos.

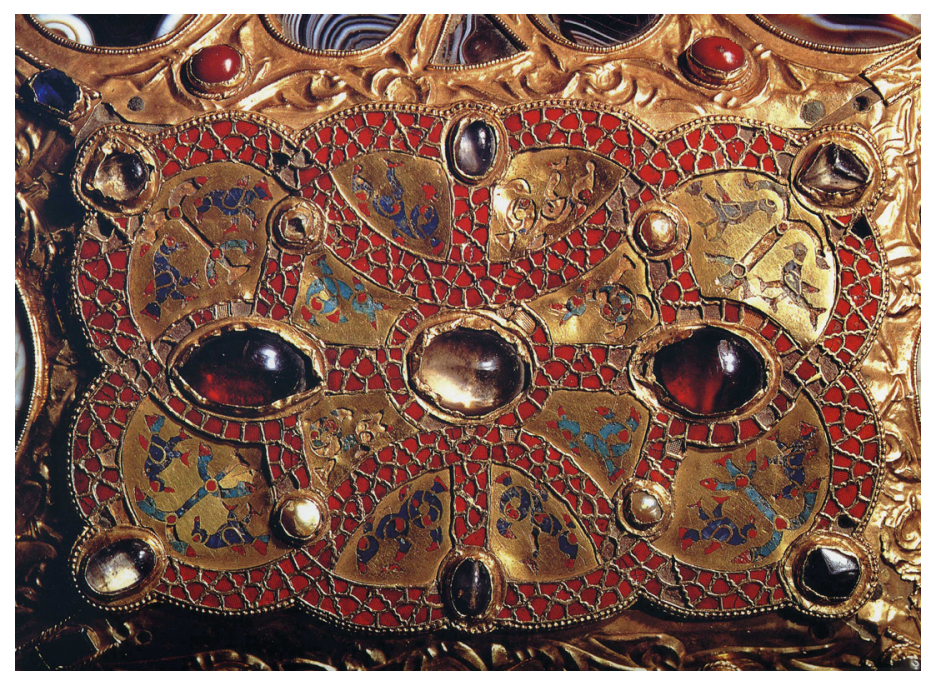

Fig. 7. Arqueta de las Ágatas. Placa superior. Foto: Archivo Deutsches Archäologisches Institut, Abteilung Madrid.

61 J. MANZANARES RODRÍGUEZ, op. cit., 1972, p. 19. 
En primer lugar, una cinta de aproximadamente un centímetro de sección recorre todo el perímetro exterior, adaptada a los doce lóbulos -cuatro en los lados mayores y dos en los menores- de su diseño. Los bordes exterior y interior de esta cinta están constituidos por sendas laminillas continuas de oro, colocadas verticalmente. El borde exterior está reforzado externamente por una estructura de vástagos dispuestos oblicuamente en zigzag, que delimitan celdillas triangulares, a los que se suelda el cordoncillo torso que remata el contorno. El canal interior así delimitado está recorrido por una laminilla vertical de trayectoria ondulada, y dividido en multitud de celdillas por tabiques de laminillas de oro de trayectoria quebrada, que van conformando alvéolos triangulares o trapeciales, rellenos de materia roja.

En segundo lugar, dentro de la placa, la misma cinta estructura la organización interna, destinada a delimitar los campos de los doce esmaltes y los trece engastes con los que está dotada. Así, tres grandes cabujones en el eje mayor y otros dos cabujones más pequeños en el menor, aplicados en la intersección de los lóbulos segundo y tercero de los lados mayores, definen una cruz. Todos los engastes están enlazados entre sí por cuatro trazos de cinta doble. Los cabujones que definen el mástil están rodeados por cinta simple; no así los del travesaño, que se emplazan interrumpiendo la cinta perimetral. A ambos lados del eje vertical, y uniendo los dos lóbulos centrales de cada lado mayor por el interior, la cinta dibuja sendas curvas tangentes al gran cabujón central. Exactamente en los cuatro puntos de unión de estas curvas con la cinta perimetral se emplazan los restantes cuatro cabujones de la placa, los de menor tamaño, unidos también mediante cinta doble a los cabujones extremos del mástil de la cruz. Su función práctica fue ocultar los cuatro agujeros por los que se introdujo un cable doble, a su vez insertado en los taladros que perforan en su totalidad el panel superior del armazón de madera, tras cuya perforación se desdoblan y abren los dos cabos hacia el exterior, permitiendo su sujeción al mismo ${ }^{62}$.

Manzanares contó 655 celdillas, advirtiendo pérdidas del relleno en 64 de ellas ${ }^{63}$. La superficie superior suma 419 -214 en la franja exterior, 50 en cada franja curva lateral y 105 en las franjas de enlace entre cabujones y marcos de estos-. Las restantes 236 configuran los alvéolos triangulares del alzado exterior. La historiografía se ha referido mayoritariamente al material que rellena estas celdillas como trozos de granates almandinos, es decir, "silicato doble de alúmina y de hierro u otros óxidos metálicos (...), de color rojo o violeta, muy usado en joyería" (DRAE, ed. 2001, S.v. $)^{64}$. Sin embargo, la memoria de la restauración de la pieza se refiere a ellos en todo momento como vidrios o esmaltes rojos ${ }^{65}$. El problema no carece de trascen-

62 C. ÁlVAREZ DE BENITO, op. cit., 2002a, p. 430. Este fue el sistema empleado para presentar y colocar la placa reproducida en la reconstrucción tras 1977, antes de haber sido recuperada la placa original.

63 J. MANZANARES RODRÍGUEZ, op. cit., 1972, p. 19.

64 Ibid., p. 19: "cristales de granate (almandina)"; S. NOACK-HALEY, op. cit., 1993, p. 144: "lustrous red almandines", y op. cit., 1999, p. 186: "in Zellen eingelegte, leuchtend rote Almandine”; V.H. ELBERN, op. cit., 2008, p. 183: "granates almandinos"; G. HASELOFF, op. cit., 1990, p. 84: "Bänderwerk aus rotem Almandin"; C. CID PRIEGO, op. cit. (1995-1996), p. 28: "cristales de granate"; e I. RUIZ DE LA PEÑA GONZÁLEZ, op. cit., 2000, p. 221: "cristalitos granates tabicados", "cristales de granates tabicados".

65 C. ÁlVAREZ DE BENITO, op. cit., 2002a, pp. 430-438. De hecho, en la confección de la placa sustitutoria de la inicialmente perdida en 1977 el orfebre se encontró con la dificultad de resolver el problema 
dencia, ya que, aparte del establecimiento de un hecho objetivo, cual es determinar la naturaleza mineralógica de los elementos de adorno, el hecho de inclinarse por una u otra caracterización es de capital importancia a la hora de calibrar la capacidad técnica de la orfebrería del s. VIII. En primer lugar, de tratarse de minerales, es decir de granates almandinos, con una dureza en torno al $7 \mathrm{Mohs}^{66}$, su talla se revela muy difícil en la fecha, máxime cuando los fragmentos que han de emplearse para la inserción en las celdillas son de tamaño milimétrico y se encuentran predeterminados por las laminillas que conforman las mismas, de trayectoria quebrada y curva, lo que provoca una enorme dificultad y una laboriosidad prácticamente inconcebibles. Por el contrario, si se trata de esmaltes, su inserción no ofrece dificultades mecánicas -pues la materia prima se introduce en las celdillas en estado pastoso-, y la obtención del producto final es unitaria, requiriendo solamente pericia técnica en la manipulación de la temperatura y tiempo de fusión.

De las pruebas y análisis efectuados tanto para reproducir la placa como para restaurarla reintegrando el relleno a la pieza original recuperada se obtuvieron datos definitivos para esclarecer el problema. La observación al microscopio de fragmentos inclasificados de láminas de oro recuperados del expolio dio como resultado el descubrimiento de restos de vidrio rojo adheridos:

"la conclusión es que las orlas estaban rellenas y tapadas en su parte superior con una fina lámina de oro adaptada perfectamente a las celdillas y algo embutida en éstas. Aquí iban los esmaltes de espesor muy pequeño" ${ }^{\circ 7}$.

De hecho, esta observación, además de confirmar que las celdillas estaban esmaltadas y no rellenas con granates, permitió reproducir el procedimiento técnico seguido para la confección de la banda, que ya hemos descrito.

Una vez construida la banda roja, quedan delimitados así doce campos donde se colocan las doce plaquitas esmaltadas que han concentrado el interés de la investigación técnica e iconográfico-iconológica de la pieza. Elbern estableció en 1961 que los esmaltes figurativos de la placa habían sido realizados mediante la técnica mixta del esmalte hundido (Senkschmelz), consistente en soldar una lámina abombada con el contorno recortado del motivo a la placa base, delimitar mediante tabiques verticales los campos a esmaltar y rellenar, enrasando con la lámina superior la superficie final del esmalte ${ }^{68}$. Nuevamente, Álvarez de Benito pudo confirmar esta aseveración: efectivamente, 11 de los esmaltes -todos salvo el $\mathrm{n}^{\mathrm{o}} 4$, situado en la esquina trasera derecha de la placa-

del relleno de las celdillas de la cinta. El plan inicialmente concebido fue esmaltar de corrido toda la cinta. Se encargó de ello el responsable del taller del monasterio de Santo Domingo de Silos, Regino López, quien confesó la imposibilidad técnica de efectuar la operación, por el rechazo ofrecido por el marco de oro. Ante esta circunstancia, se recabó opinión del taller de J.M. Nicolau, de Barcelona. Realizadas las pruebas, se cosechó un nuevo fracaso, debido esta vez a la formación de burbujas que estallaban en la superficie (ibid., pp. 434-435).

66 Dato que debo a la amabilidad de Dña. Celia Marcos Novo, del Departamento de Geología de la Universidad de Oviedo.

67 C. ÁLVAREZ DE BENITO, op. cit., 2002a, p. 437.

68 V.H. ELBERN, op. cit., 2008, p. 186. Certifica la técnica G. HASELOFF, op. cit., 1990, p. 84. Cf. También M.-M. GAUTHIER, Émaux du Moyen Âge occidental, Fribourg, 1972, pp. 40-41. 
"están fabricados tomando una chapa de oro y calando o recortando el dibujo sobre esta. Después esta chapa calada se coloca sobre otra a la que se suelda".

El esmalte restante está realizado, por el contrario, "con el dibujo excavado con un buril" -técnica del esmalte en fosa-, el color del oro y de la pasta vítrea es diferente y la ejecución es de peor calidad. Concluye que esta plaquita es producto de una reposición posterior, por pérdida del original ${ }^{69}$. Los cuerpos de los animales alternan los componentes azul oscuro, azul turquesa y rojo, con especial presencia del rojo en las extremidades.

La iconografía de las doce plaquitas esmaltadas ha sido igualmente estudiada por Schlunk y Elbern: pájaros, cuadrúpedos y reptiles, los tria genera animantium, dispuestos alrededor de la Cruz. Haseloff ha precisado la identificación zoológica: delfines para los reptiles, hipocampos para los cuadrúpedos, conforme a patrones formales bien establecidos desde la Antigüedad clásica ${ }^{70}$. Su orden es simétrico: cuatro placas con sendos pares de pájaros afrontados a un vástago vegetal con triple raíz y doble rama, en los extremos del eje vertical, cuatro placas con reptiles solitarios en los campos situados en torno al gran cabujón central, y otras cuatro placas con cuadrúpedos solitarios insertas dos a dos en los campos definidos por las bandas curvas interiores. El orden es, por tanto, pájaros-reptiles-cuadrúpedos-cuadrúpedos-reptilespájaros, o bien, pájaros-delfines-hipocampos-hipocampos-delfines-pájaros. La forma de las placas es específica para cada género: semicírculo para los pájaros, trapecio irregular para los reptiles-delfines, triángulo de lados convexos para los cuadrúpedoshipocampos ${ }^{71}$. Está doblado el número de pájaros frente a los otros dos géneros, pero el número de plaquitas, doce, se inserta en la tradición ejemplificada por Lindau y Enger. Los análisis estilísticos han desmentido la posibilidad de que las plaquitas hubieran sido realizadas en el mismo taller. El carácter degenerado formalmente de las plaquitas de Enger frente a Lindau y Oviedo asigna a estas precedencia cronológica frente a aquella ${ }^{72}$. La fecha propuesta por Elbern -primera mitad o mediados del VIII-, sin embargo, ha sido revisada por Haseloff, quien ha establecido que la aparición del esmalte hundido o tabicado en Occidente no es anterior a la conquista del norte de la Península Itálica por el reino franco a partir de la década de 770, circunstancia que permitió el contacto con las labores bizantinas e importar la figuración de motivos mitológicos clásicos, como los hipocampos y los delfines. Por ello, la placa ha de ser asignada a un taller alamánico-franco de fines del VIII, inserto en el mismo círculo productivo que la bolsa de Enger, la tapa antigua del Evangeliario de Lindau, la cruz de Quierzy y la plaquita engastada en el medallón central de la desaparecida cruz de Santiago de Compostela, denominado "provincia insular de Salzburgo"73.

69 C. ÁlVAREZ DE BENITO, op. cit., 2002a, p. 430. Pese a ello, I. RUIZ DE LA PEÑA GONZÁLEZ, op. cit., 2000, p. 221, los define como "esmaltes campeados".

70 G. HASELOFF, op. cit., 1990, p. 85. Ello puede tener repercusiones sobre la interpretación iconológica de la placa propuesta por Elbern.

71 Observación ya efectuada por el mismo G. HASELOFF, op. cit., 1990, p. 84.

72 V.H. ELBERN, op. cit., 2008, p. 193.

73 G. HASELOFF, op. cit., 1990, pp. 77 y 90-91. Sobre la mencionada provincia, V.H. ELBERN, "Zwischen England und Oberitalien. Die sogennante Insulare Kunstprovinz in Salzburg”, P. SKUBISZEWSKI (ed.), op. 
Sobre la función de la placa, la opinión prevaleciente hasta el análisis de la reconstrucción era considerarla parte de un relicario, como tapa de arqueta, o relicario ella misma; en todo caso, un objeto sacro ${ }^{74}$. El examen del reverso de la pieza una vez recuperada permitió apreciar supuestamente que quedaban "claros restos de aguja y enganche que la definen como broche" 75 . La propuesta de un destino laico, como broche, ya había sido expresada por Cuesta y Díaz Caneja en $1961^{76}$, en tanto que Schlunk, en 1950, constató que nada en ella habla explícitamente de un uso eclesiástico, indicando que tal vez formara parte de una cajita de su misma forma ${ }^{77}$.

La documentación fotográfica publicada sobre este importante aspecto de la placa es muy insuficiente y no está acompañada de la necesaria descripción textual. No obstante, la observación de las fotografías originales ${ }^{78}$ permite despejar dudas. Se aprecian en el reverso, junto a los taladros de inserción de los cables de sujeción al armazón de madera, tres aros alargados de cordón torso de hilo de oro, que se encuentran aplastados contra la superficie del reverso. El diámetro de los dos mayores es poco mayor que un centímetro; el menor, de milímetros. Los tres se encuentran soldados a la placa en el mismo eje, desplazados del central. No están, por tanto, aplastados, como se ha publicado. Uno de ellos se limita a un sector de circunferencia. En el interior de los aros se encuentra un segundo anillo de finísima laminilla de oro. Se trata de restos de engastes compuestos por lámina interior y cordón de filigrana perlada exterior. La placa de base ha sido, en consecuencia, reutilizada, tras haber sido iniciada en ella la colocación de tres engastes.

No se ha descrito el mecanismo de funcionamiento del hipotético broche. Las abundantísimas fíbulas de sujeción de un manto o capa fechadas entre los siglos $\mathrm{V}$ y VIII poseen todas el mismo mecanismo de sujeción, consistente en una aguja basculante, que se introduce en el tejido por dos puntos, y una mortaja o gancho donde se inserta a presión manteniendo fijo el broche al tejido, ambos colocados en el eje central de la pieza, circular o cuadrangular, pero en cualquier caso de diseño centrípeto y contorno equidistante del centro. No hay huella de la aguja ni de su enganche -bien de muelle, bien de vástago entre ojales-, ni tampoco de la mortaja de fijación, que en todos los casos son piezas de grosor y resistencia adecuadas a la misión que se les encomienda. La placa resulta, por otro lado, de un formato y unas dimensiones absolutamente fuera de escala en las tipologías de fíbulas altomedievales, que apenas superan los $11 \mathrm{~cm}$ de diámetro en los ejemplares mayores ${ }^{79}$. En resumen, no hay evi-

cit., 1998, pp. 210-225.

74 V.H. ELBERN, op. cit., 2008, pp. 206-207; S. NOACK-HALEY, op. cit., 1993, p. 144. Para J. MANZANARES RODRÍGUEZ, op. cit., 1972, p. 20, permanece inconcreto su destino, pero posiblemente fuera parte de otra caja.

75 C. CID PRIEGO, op. cit., 1995, p. 330, у op. cit. (1995-1996), p. 28; C. BURGOS, op. cit., 2004, p. 55.

76 J. CUESTA FERNÁNDEZ y M. DÍAZ CANEJA, op. cit. (1958), pp. 12-13.

77 H. SCHLUNK, op. cit., 2008, p. 101.

78 Es gentileza del restaurador, D. Carlos Álvarez de Benito. En sendas conversaciones mantenidas el 28 de agosto y el 6 de septiembre de 2013, observando las fotografías, convenimos en interpretar estos restos como el residuo de engastes desaparecidos. Es evidentemente imposible que el cierre de una fíbula venga sujeto a la placa base mediante un engaste semejante al de un cabujón.

79 Fíbula Fuller, del enterramiento de Sutton Hoo (British Museum, Londres): 11,4 cm (D.M. WILSON, Anglo-saxon art from the seventh century to the norman conquest, Londres, 1984, fig. 1). Vid. últimamente 
dencias ni textuales ni gráficas que permitan identificar aguja y mortaja en el reverso de la placa, sin los cuales no se puede hablar de broche. Su tamaño lo convertiría en un unicum de imposible inserción en la serie de tipologías de fíbulas altomedievales tan acreditada en la investigación arqueológica.

Abandonando la hipótesis del broche, es preciso volver a examinar la placa. El borde exterior, recorrido por celosía de celdillas con cristales, impide el encaje en una caja inferior, como ya advirtió Schlunk. No puede, por ello, haber sido tapa de caja, a lo que se opone también su contorno polilobulado, difícilmente adoptable como diseño de un contenedor, por las dificultades de su labra. La riqueza de su equipamiento en pedrería y esmaltes y la complejidad de su programa teológico hablan en contra del destino laico, según aseveración de Elbern. Lo más probable es que haya sido concebida como aplique destinado a ser fijado en otra pieza de orfebrería sacra, como fue su destino definitivo en la Arqueta de las Ágatas.

\subsection{La placa inferior}

Aplicada al panel inferior de la caja mediante 123 clavos $^{80}$ que recorren los cuatro bordes exteriores y se distribuyen con cierta simetría en los huecos dejados libres por la decoración y la inscripción, es una lámina de plata de $0,7 \mathrm{~mm}$ de espesor, de tamaño ligeramente inferior al del panel: 414 x $262 \mathrm{~mm}$ (Manzanares) (Fig. 8).

El centro de la lámina está ocupado por una cruz latina de brazos rectos, y remate en horquilla expandida, con las dos protuberancias angulares redondeadas. Cada brazo está articulado en tres tramos. El interior, rectangular, es liso y está ocupado por un motivo ovalado, dividido según el eje mayor en dos mitades por un vástago liso. Las mitades resultantes están cubiertas por líneas oblicuas paralelas, a modo de uves encajadas. El tramo intermedio, cuadrado, está dividido según las diagonales en cuatro cuartos, rellenos con líneas oblicuas, paralelas dentro de cada campo, y perpendiculares los campos entre sí. Los lados de separación con los dos tramos anejos están destacados mediante sendas molduras rectas, de las que la del brazo superior está decorada por rasgos torsos. Por último, el tramo exterior conforma el remate bilobulado, estando rehundido internamente su contorno. En el campo central figuran realzados tres bultos circulares, configurado un triángulo con el ápice apuntado hacia el interior del brazo. Paradójicamente, el contorno externo de la cruz no está delimitado por ninguna moldura, sino simplemente por línea incisa.

En el cruce de los cuatro brazos se sitúa un cuadrado idéntico al de los tramos intermedios de estos. El trazado de la cruz no es exactamente paralelo respecto

\footnotetext{
sobre las fíbulas circulares con granates: K. VIELITZ, Die Granatscheibenfibeln der Merowingerzeit, Montagnac, 2003.

80 Podría ser producto de la casualidad, pero la suma de 105 clavos del revestimiento de oro y los 123 de la placa de plata arroja un total de 228 clavos, que se descomponen en $200+28$, donde 28 es número perfecto por resultar su contracción 10 y sumar igualmente 28 la suma de sus divisores. Es posible, a título hipotético, proponer que las magnitudes de los clavos y la pedrería que fijan y complementan el revestimiento metálico de la caja han estado guiadas por la combinación de 200 más dos números perfectos, 24 y 28,224 piedras y 228 clavos.
} 


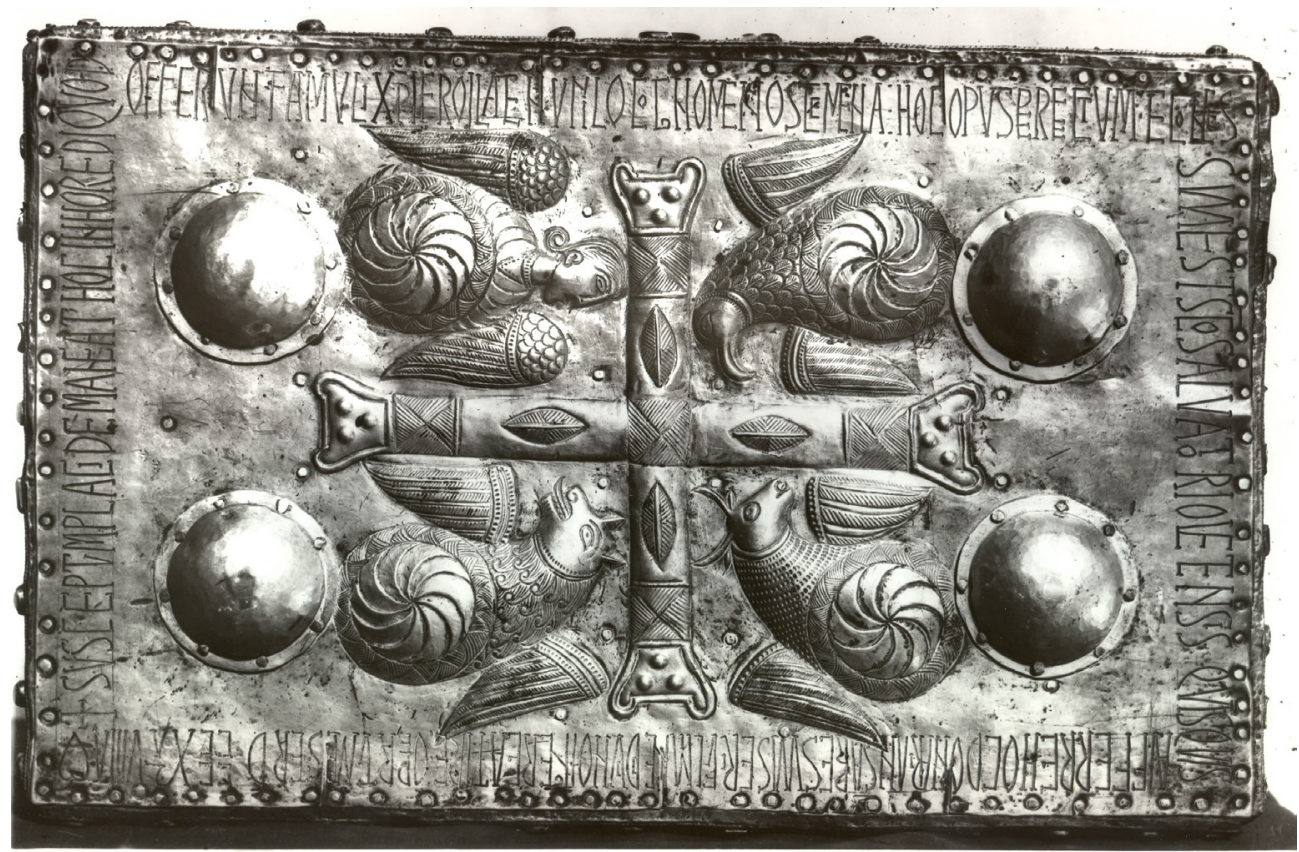

Fig. 8. Arqueta de las Ágatas. Placa inferior. Foto: Arxíu Mas, neg. C-25266.

a los dos ejes de la lámina. Mientras el mástil es paralelo al eje central vertical, el travesaño se encuentra ligeramente inclinado hacia la parte inferior izquierda. Esta circunstancia ha determinado la colocación de los cuatro restantes motivos figurativos de la pieza, el Tetramorfos.

$\mathrm{Su}$ articulación interior responde a la traducción de una crux gemmata, con un gran engaste ovalado en cada brazo, cinco grandes engastes cuadrados -o campos esmaltados- y agrupaciones de tres bultos circulares en los campos interiores de los remates. Todo ello configura un equipamiento de pedrería conformado por 4 +12 , al que se suman los cuatro campos cuadrados y el central $(1+4)$. El ritmo de dentro afuera es 1-4-4-12, muy significativo en cuanto a su potencialidad simbólica. La ausencia de medallón central, los remates bilobulados, los cuatro cuadrados en brazos y centro, y los óvalos de los brazos hacen derivar iconográficamente, sin duda alguna, esta cruz de la que preside el nivel superior de los hastiales orientales y occidentales del interior del templo ovetense de Santullano ${ }^{81}$. En ambos casos se trata de una cruz gemada. El tipo fue utilizado, en paralelo con el de la cruz griega patada con medallón central de la Cruz de los Ángeles, en diversas placas epigráficas asturianas ${ }^{82}$. No hay duda de la interpretación como

81 H. SCHLUNK y M. BERENGUER, La pintura mural asturiana de los siglos IX y X, Oviedo, 1991 (2ª ed.) (Oviedo, 1957), p. 31, láms. 3, 4, 8, 12, 13, y 18.2 .

82 Al respecto, C. GARCÍA DE CASTRO VALDÉS, "Some questions on function and iconography of the Cross in the Asturian Kingdom", J. NÍ GHRÁDÁIG, J. MULLINS y R. HAWTREE (eds.), Envisioning Christ 


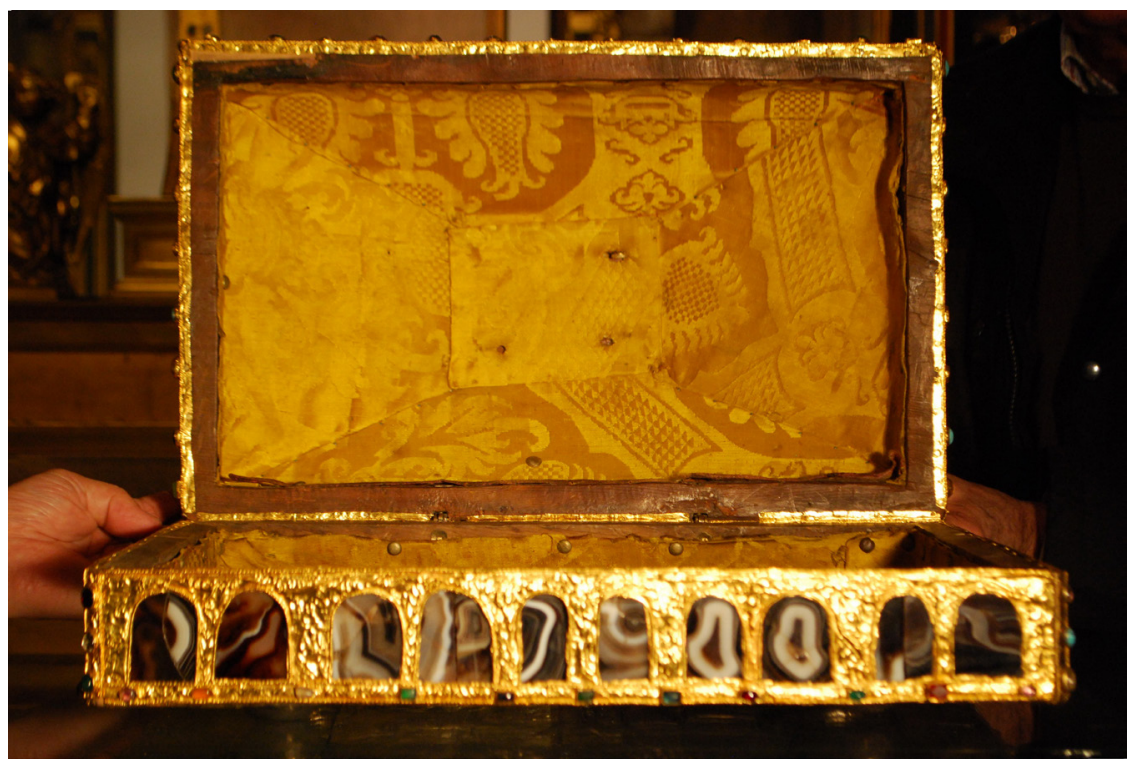

Fig. 9. Arqueta de las Ágatas. Interior de la tapa. Foto: César García de Castro Valdés.

cruz parusíaca: los remates bilobulados corresponden a las protuberancias atestiguadas por la visio Constantini la víspera del Puente Milvio ${ }^{83}$.

En los cuatro cuadrantes definidos por la cruz, y con palpable posterioridad a ella, se disponen los cuatro Vivientes de la visión de Ezequiel (1, 5-24). Su diseño sitúa las cuatro cabezas en el interior de los ángulos, lo que produce que en la contemplación normal de la placa los dos seres superiores estén invertidos cabeza abajo. En el cuadrante superior izquierdo se sitúa el león, en el superior derecho, el hombre, en el inferior izquierdo el toro, y en el inferior derecho el águila. Todos miran hacia el centro de la cruz, resultando de ello que los seres superiores y los inferiores están afrontados en torno al eje definido por el mástil. La estructura de las representaciones es muy similar en los cuatro casos. Sobre ruedas de nueve, diez u once radios curvos dextrógiros - en tres casos, salvo el águila, que asienta sobre rueda sinistrógira- con una corona exterior rellena con las habituales series de líneas oblicuas paralelas en campos triangulares perpendiculares entre sí, asientan los bustos de los cuatro Vivientes. Los rostros están representados de perfil salvo ojos, orejas y cuernos. Solamente el león muestra fauces abiertas, con los dientes incisos sobre la lengua. Cuello y arranque del pecho están cubiertos por tramas ornamentales a modo de recubrimiento escamoso, de plumas en el águila, guedejas rizadas en el león, campo puntillado inciso en

on the Cross in the Early Medieval West, Dublín, 2013, pp. 103-124.

83 C. GARCÍA DE CASTRO VALDÉS, "Génesis y tipología de la cruz gemada en Occidente", F.J. FERNÁNDEZ CONDE y C. GARCÍA DE CASTRO VALDÉS (eds.), Poder y Simbología en Europa, siglos VII-X, anejo $\mathrm{n}^{\circ} 2$ de Territorio, Sociedad y Poder (2009), pp. 371-400, esp. 382-383, con bibliografía. 


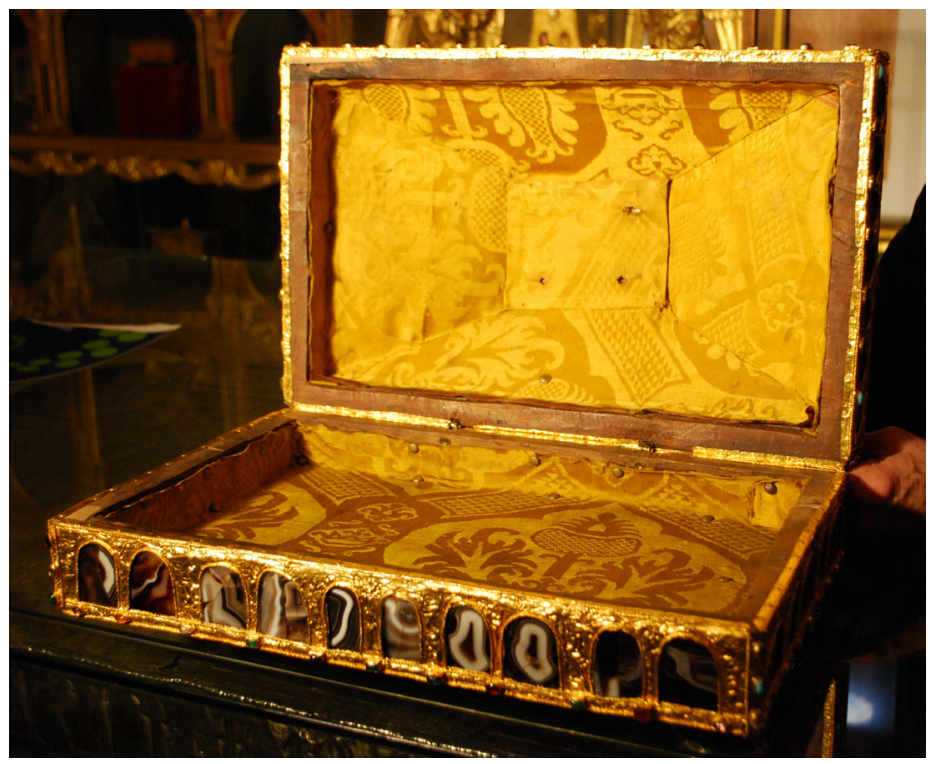

Fig. 10. Arqueta de las Ágatas. Interior de la caja. Foto: César García de Castro Valdés.

el toro, y túnica ondulada con cuello y escote ribeteado con puntos en el hombre. Yuxtapuestas y sin enlace orgánico alguno con los bustos se adosan las alas. En los casos de los tres animales, cada ala se inserta a altura distinta en el hombro correspondiente, con patente intención de alcanzar tangencialmente a ambos brazos de la cruz. Por el contrario, el hombre dispone su par de alas inserto a la misma altura de los hombros, por lo que se mantienen paralelos al travesaño de la cruz. Este tratamiento diferente de la figura del hombre se extiende al diseño de las alas. Todas son plenamente ornamentales y constan de dos partes. En los tres animales, el hombro está formado por un campo curvo, compuesto por una -en el caso del toro- o dos -en águila y león- bandas externas punteadas separadas por una interior lisa, mientras que en el hombre, el hombro está formado por un semicírculo relleno con escamas ${ }^{84}$ y cerrado por abajo por una banda punteada, figurando las plumas coberteras. La parte inferior del ala consta de cuatro o cinco bandas paralelas rellenas de líneas oblicuas paralelas, representando las plumas remeras.

Técnicamente, todas las figuras están repujadas, aplicándose el grabado lineal sobre los volúmenes resaltados, tanto para delimitar los campos como para rellenar las superficies interiores.

84 El tema decorativo del campo de escamas es frecuente en la platería carolingia. Se emplea en el relleno de los campos de la píxide de Ribe (Nationalmuseet, Copenhague) y en varias representaciones de alas de ángeles en encuadernaciones (Evangeliario de Lorsch, Salterio de Corbie), miniaturas (Salterio de Stuttgart) o dípticos ebúrneos (David y Gregorio Magno, Monza). Vid. E. WAMERS, op. cit. (1991), p. 132, nn. $102-103$. 
Se trata igualmente de una lámina adventicia, de menores dimensiones que la caja y verosímilmente reaprovechada, habiéndole sido adaptada la inscripción. Es patente que la inscripción es posterior a la representación de Cruz y Tetramorfos. Allí donde las representaciones figurativas entran en contacto con las letras, se aprecia con toda evidencia que las letras se adaptan al contorno de las figuras, alas en particular. Así sucede con las N, S y A de NOSTRA, sobre el ala izquierda del toro de San Lucas y con la E de IPSE sobre el ala derecha del león de San Marcos ${ }^{85}$. La técnica epigráfica es la incisión simple utilizando un cincel de punta biselada, cuya acción deja un surco punteado que contrasta llamativamente con las líneas incisas continuas del resto de la lámina. Es un rasgo más a favor de la tesis que sostenemos del aprovechamiento de la pieza y su adaptación a la caja.

Los pies semicilíndricos ocultan mínimamente la figuración, pisando las circunferencias de las ruedas helicoidales: son adventicios también. Los clavitos que los fijan a la madera son iguales que los utilizados para la lámina de plata, lo que permite proponer su coetaneidad tanto cronológica como funcional: fueron colocados una vez que se fijó la lámina como solera exterior de la arqueta y lugar de la inscripción dotacional, para evitar el desgaste de la superficie repujada por roce.

Esta técnica y el hecho de haber utilizado una lámina preexistente para colocar la inscripción diferencian absolutamente la Arqueta de las Ágatas de las precedentes joyas asturianas. En efecto, en las tres cruces de los Ángeles, de Santiago y de la Victoria, el texto dotacional está compuesto por letras y signos de puntuación recortados en lámina de oro y soldados uno a uno a la plancha del revestimiento de la joya. Por su parte, los textos de la arqueta de la catedral de Astorga están formados por letras repujadas que forman parte de la lámina en la que se insertan.

Una plancha parecida constituye la solera de la arqueta de Astorga. En su centro figura una cruz latina de brazos rectos y estrechos, con remates bilobulados, carente de medallón central y de pedrería. A y $\Omega$ penden de sendos cordones trenzados de doble cabo de los brazos laterales, a los que se fijan en el canto superior candeleros trifoliados. No hay, ni hubo, Tetramorfos. Temática crucífera es frecuente en las estaurotecas mediobizantinas, que aplican una placa con cruz gemada o vegetal, en la base o reverso de la caja, como la estauroteca Fieschi $\operatorname{Morgan}^{86}$, la de la Procuradoria de San Marco en Venecia ${ }^{87}$, la del Gosudarstvennyj Ermitaž/Museo del Ermitage de Sankt Petersburg ${ }^{88}$, o la tapa del Musée du Louvre ${ }^{89}$.

85 J. CUESTA FERNÁNDEZ y M. DÍAZ CANEJA, op. cit. (1958), p. 9, y S. NOACK-HALEY, op. cit., 1993, p. 145, n. 2, apuntan la posterioridad de la inscripción respecto a las representaciones figurativas.

86 T.F. MATTHEWS, "The Fieschi Morgan Staurotheke", The Glory of Byzantium. Art and Culture of the Middle Byzantine Era. A.D. 843-1261, Nueva York, 1997, n³ 34, p. 74.

87 J.C. ANDERSON, "Staurotheke”, The Glory of Byzantium..., op. cit., 1997, nº 37, p. 79.

88 The Glory of Byzantium..., op. cit., 1997, no 38.

89 A. CUTLER y J.-M. SPIESER, Byzance médiévale 700-1204, París, 1996, p. 344, ill. 271-272. 


\title{
5. La inscripción de donación: aspectos paleográficos, textuales y topográficos
}

Transcripción.

\author{
+ SVSCEPTVM PLACIDE MANEAT HOC IN HO $<$ NO $>$ RE D $<$ E $>$ I/ \\ QVOD OFFERVNT FAMVLI XP $<$ IST $>$ I FROILA ET NVNILO COGNOMENTO \\ SCEMENA. HOC OPVS PERFECTVM ET CONCES/ \\ SVM EST $\mathrm{S}<\mathrm{AN}>\mathrm{C}<\mathrm{T}>0$ SALVATORI OVETENSIS. QVISQVIS/ \\ AVFERRE HOC DONARIA $\mathrm{N}<\mathrm{O}>\mathrm{S}<\mathrm{TR}>\mathrm{A}$ PRESVMSERI FVLMINE DIVINO \\ INTEREAT IPSE: OPERATVM EST ERA D CCCC XLA VIIIA (hedera) ${ }^{90}$.
}

Las características paleográficas a destacar de esta inscripción son el módulo muy alargado de las letras; la presencia constante de trazos finales; la práctica ausencia de abreviaturas (DI; XPI; HORE; SCO; NSA); la presencia de nexos sencillos (TV, NE, TF, NT, ME, ET, VM, VE, TE, AV, AR, FV, NTE, RA, ME); la ausencia de signos de puntuación, salvo tres puntos verticales ante la última frase y la hedera final tras la fecha; y la presencia discreta pero repetida de letras encajadas y sobrepuestas. En cuanto a la forma de las letras, la A se presenta con travesaño horizontal o sin él, pero nunca con angular; la $\mathrm{C}$ siempre cuadrada, D curva, E y F cuadradas, L recta, salvo la de la fecha, $\mathrm{M}$ inclinada, $\mathrm{N}$ de travesaño, $\mathrm{O}$ ovalada, $\mathrm{Q}$ mayúscula, $\mathrm{R}$ de asta recta, $\mathrm{T}$ de travesaño horizontal, con un solo caso de rasgo vuelto, $\mathrm{V}$ capital, nunca uncial.

Desde el punto de vista de los rasgos paleográficos, pueden señalarse paralelos en la coetánea epigrafía monumental asturleonesa: inscripción fundacional de San Salvador de Távara, fechada a fines del IX ${ }^{91}$; inscripción fundacional de San Pedro de Montes, del 919 ${ }^{92}$; inscripción fundacional de Santo Adriano de Boñar, de similar entorno cronológico ${ }^{93}$; inscripción fundacional de Santa Eulalia de Morcín, datada entre 906-92694; conjunto de inscripciones de San Martín de Salas, del 95195. En cuanto a la epigrafía fundacional ovetense, puede señalarse cierto parecido con las dos inscripciones procedentes del castillo-fortaleza, del $875^{96}$, semejantes a las inscripciones de la fase I de San Salvador de Valdediós (dintel de la puerta occidental, dinteles de las puertas interiores de las dependencias laterales) ${ }^{97}$. Mayores diferencias se observan con la inscripción consecratoria de San Salvador de Valdediós, correspondiente a la fase II, del $893^{98}$. A mayor distancia se sitúan los epitafios de Martinus, del 1047, y

90 Esto que ofrecieron los siervos de Cristo Froila y Nunilo, llamada Scemena, permanezca acogido con gozo en honor de Dios. Esta obra fue acabada y concedida a San Salvador de Oviedo. Quien se atreviere a arrebatar estos dones nuestros, sea muerto por el rayo divino. Fue elaborado en la Era 948 (año 910).

91 A. BLANCO FREIJEIRO y R. CORZO SÁNCHEZ, "Lápida fundacional de San Salvador de Tábara", Actas del Simposio para el estudio de los códices del Comentario al Apocalipsis de Beato de Liébana. I, Madrid, 1980, pp. 275-277.

92 M. GÓMEZ MORENO, op. cit., 1919, Lám. LXXIX.

93 Ibid., Lám. LV.

94 C. GARCÍA DE CASTRO VALDÉS, op. cit., 1995, fot. 76.

95 Ibid., fot. $78-84$.

96 Ibid., fot. 38.

97 Ibid., fot. 72-74.

98 Ibid., fot. 71. 
Vidramirus, del 1058, de la necrópolis de la Catedral de Santiago ${ }^{99}$, así como la serie de epitafios mozárabes del X y del XI ${ }^{100}$. Ningún paralelo se observa, sin embargo, en la epigrafía funeraria asturleonesa coetánea ${ }^{101}$.

En Asturias, las inscripciones de las tres cruces, tratándose de capitales cuadradas, difieren profundamente de este repertorio formal. Aún así, la cercanía es mayor con las cruces tardías, de Santiago de Compostela (874) y de la Victoria (908), sobre todo en rasgos diagnósticos, como la $\mathrm{Q}$ mayúscula, la $\mathrm{D}$ mayúscula de la fecha, ambas minúsculas en la Cruz de los Ángeles (808), y la ausencia de A con travesaño angular, frecuente en esta última cruz. Nada comparte formalmente esta epigrafía de la Arqueta de las Ágatas con la caja astorgana donada por Alfonso III y Scemena. En este caso, las letras están repujadas y responden a tipos cuadrados. Tampoco se aprecia paralelo formal alguno con la leyenda de la cruz de Santiago de Peñalba, del 940, que sí ha sido labrada con un tipo de incisión en zigzag, de efecto semejante al de la Arqueta ovetense. Las letras encajadas y sobrepuestas, absolutamente ausentes en las joyas precedentes, aparecen tímidamente en la inscripción de Montes y con mayor decisión en las de Távara y Boñar, mientras que se hacen normales en los epitafios santiagueses. Entre las escrituras librarias se encuentran cercanos paralelos paleográficos en el ejemplar de las Etymologiae isidorianas copiado para Sancha de León en 1047 por Veremundus y Dominicus (Escorial, \&.I.3, fol. 9) ${ }^{102}$.

Por el contrario, los paralelos textuales son abundantes en las tres cruces asturianas. A continuación insertamos los textos respectivos, subrayando las palabras comunes.

Cruz de los Ángeles:

+ SVSCEPTVM PLACIDE MANEAT HOC IN HONORE $D<$ E $>$ I/

OFFERT ADEFONSVS HVMILIS SERVVS XR $<$ IST $>$ I

HOC SIGNO TVETVR PIVS/

HOC SIGNO VINCITVR INIMICVS/

QVISQVIS AVFERRE PRESVMSERIT MIHI/

FVLMINE DIVINO INTEREAT IPSE/

NISI LIBENS VBI VOLVNTAS DEDERIT MEA/

HOC O(PVS) PERFECTVM EST IN ERA dCCCXLVI/

Cruz de Santiago:

+OB HONOREM $\mathrm{S}<\mathrm{AN}>\mathrm{C}<\mathrm{T}>$ I IACOBI Ap $<$ osto $>$ li/

OFFERVNT FAMVLI /

Adefonsvs PRInceps et conjuge/

SCEMENA REGINa/

99 J. GUERRA CAMPOS, Exploraciones arqueológicas en torno al sepulcro del Apóstol Santiago, Santiago de Compostela, 1982, pp. 466-467.

100 M. GÓMEZ MORENO, op. cit., 1919, pp. 365-369, Lám. CXXXI;

101 Catálogo de las piezas asturianas en C. GARCÍA DE CASTRO VALDÉS, op. cit., 1995, pp. 57-80 y 167-176.

102 M.C. DÍAZ Y DÍAZ, Códices visigóticos en la monarquía leonesa, León, 1983, pp. 381-383, lám. 18. 
HOC OPVS PERfECTVM ESt/

IN ERA DCCCC A DVODECIMA/

HOC SIGNO VINCITVR INIMICVS/

HOC SIGNO TVETVR PIVS/

Cruz de la Victoria (908):

\author{
+ SVSCEPTVM PLACIDE MANEAT HOC IN HO $<$ NO $>$ RE $\mathrm{D}<\mathrm{E}>\mathrm{I} /$ \\ QVOD OFFERVNT FAMVLI XP<IST $>$ I ADEFONSVS PRINCES ET SCE- \\ MENA REGINA/ \\ QVISQVIS AVFERRE HOC DONARIA NOSTRA PRESVMSERIT FVLMI- \\ NE DIVINO INTEREAT IPSE/ \\ HOC OPVS PERFECTVM ET CONCESSVM EST SANCTO SALVATORI \\ OVETENSE SEDIS/ \\ HOC SIGNO TVETVR PIVS HOC SIGNO VINCITVR INIMICVS/ \\ ET OPERATVM ES(T) IN CASTELLO GAVZON ANNO REGNI/ $\mathrm{N}<\mathrm{O}>\mathrm{S}<\mathrm{TR}>\mathrm{I}$ \\ XLII DISCVRRENTE ERA DCCCCXLVIA/
}

De la simple comparación de las palabras compartidas por las cuatro joyas, resulta patente que Fruela II y Nunilo se han inspirado estrechísimamente en el texto de la donación de la Cruz de la Victoria, dos años anterior. Han seguido al pie de la letra la fórmula de su padre y suegro, ajustando el texto a las posibilidades físicas de acogida de la plancha de la base. Cobra así cierta verosimilitud la intuición de Noack-Haley de que con la donación de la arqueta Fruela quisiera emular la munificencia de su padre, apareciendo públicamente con gesto regio ${ }^{103}$, en clara competición con sus hermanos por el trono -aún ocupado por su padre, muerto en diciembre de 910-. De este modo, tal vez la placa franca habría sido igualmente aportada por la misma pareja de donantes, con patente intención de asociarse con algo personal a los beneficios derivados de la dedicación sacra del objeto. Es inverosímil toda otra propuesta alternativa, pues solamente del donante salen los materiales para la donación, máxime cuando, como en este caso, la pieza es de altísimo valor ${ }^{104}$.

El emplazamiento del nombre de los donantes, en la base de la caja, contrasta fuertemente con la ostentación de los mismos por parte de Alfonso III y Scemena en la cubierta de la arqueta de Astorga, flanqueando al Agnus Dei y con una tipografía que los iguala a los rótulos de los evangelistas y los ángeles. Los precedentes letreros de las tres cruces asturianas se sitúan en el reverso, con clara voluntad de visibilidad, siguiendo una práctica tardoantigua y que parece extinguirse a lo largo del s. X, pasando los nombres de los oferentes a ocupar lugares marginales o secundarios ${ }^{105}$. Entre los relicarios altomedievales se pueden señalar algunos paralelos en el empla-

103 S. NOACK-HALEY, op. cit., 1999, p. 186.

104 Una opinión carente de respaldo documental, que se ha hecho moneda común y parece arrancar de Cuesta (J. CUESTA FERNÁNDEZ, op. cit., 1995, p. 201), explica la presencia de esta pieza en Oviedo como un regalo de Carlomagno a Alfonso II. Schlunk, por su parte, ya sugiere que tanto esta placa como la de la Cruz de Santiago son regalos de los respectivos donantes (H. SCHLUNK, op. cit., 2008, p. 105).

105 Estudio de la cuestión en cruces orfebrísticas en C. GARCÍA DE CASTRO VALDÉS, "Significados de la orfebrería sacra en la Alta Edad Media: Alfonso II y la Cruz de Los Ángeles de San Salvador de Oviedo 
zamiento de la inscripción en la base de la caja, como los de Altheus (Pfarrkirche, Sion/Sitten) y Warnebertus (Stiftschatz, Beromünster) ${ }^{106}$.

\section{Perspectivas de estudio}

\subsection{La elección del formato y las dimensiones}

La elección de la madera de ciprés no es casual, habida cuenta de que se trata de una especie inexistente en la biocenosis del Cantábrico. Se trata de una madera que por su contenido en resina se revela muy resistente a la humedad y repelente de los agentes xilófagos: en definitiva, es garantía para la confección de un contenedor seguro ${ }^{107}$. Las joyas precedentes fueron construidas con almas de cerezo (Cruz de los Ángeles) y roble (Cruz de la Victoria), ambas especies locales. Ha habido por ello una clara voluntad de escoger una madera mediterránea, cargada además de las más prestigiosas referencias bíblicas: los objetos construidos con madera de ciprés incluyen el Arca de Noé (Gn 6, 14), y el templo de Salomón (I Re, 5, 22-24; 6, 15; 6, 34; I Cr, 2, 7; 2 $\mathrm{Cr}, 3,5)^{108}$. De resultar cierta la inspiración, es evidente que la decisión cristiana se dirige a las obras tipificadas exegéticamente como antecedentes o prefiguraciones de la Iglesia y rehúye los objetos específicamente concebidos para el culto judaico. Ello, obviamente, pone en la pista del sentido del objeto y sus antecedentes en el plano simbólico. Cabe anotar, en este sentido, que se debe al papa León III (795-816) la confección de un arca de ciprés, destinada a acoger las más destacadas de las reliquias del Sancta Sanctorum lateranense, colocado bajo su altar mayor, y mandado recubrir de plata por Inocencio III ${ }^{109}$.

(808)", A. GARCÍA LEAL (coord.), Las donaciones piadosas en el mundo medieval, Oviedo, 2012, pp. 119164, esp. 142-144.

106 Sobre estas piezas, $c f$. D. QUAST, Das merowingerzeitliche Reliquiarkästchen aus Ennabeuren, Maguncia, 2012, Grupo 1, no 3, p. 121 (Beromünster); Grupo 1, no 13, pp. 122-123 (Sion/Sitten).

107 Circunstancias que ya fueron aducidas como motivo de esta elección por E.C. GIRBAL a propósito de la arqueta de la catedral de Gerona: "Arqueta relicario de la catedral de Gerona", Museo Español de Antigüedades, VIII (1877), pp. 331-336, esp. p. 332, donde se afirma que está construida con madera de ciprés. No obstante, el análisis de una muestra extraída de un fragmento del interior (muestra TcatGi_1) ha revelado que se trata de "madera de la familia de las Pinaceae, posiblemente del género Picea (abeto falso, muy apreciado para elaborar instrumentos musicales) o del Larix (Alerce común) que no se pudre y es muy apreciada para trabajos delicados en madera". Cf. P. GIRÁLDEZ, S. BOULARAND y M. VENDRELL (Patrimoni. Estudis del patrimoni històric-Universitat de Barcelona): Arqueta de Hisam II. Estudio de los materiales constitutivos, Informe inédito, Barcelona, 2007. Ambas especies, propias de la Europa septentrional y de las montañas del arco alpino, se encuentran muy alejadas del al-Andalus. Como no cabe dudar de la confección andalusí de la pieza, atestiguada por la inscripción, queda la cuestión abierta sobre las vías y el contexto de llegada de esta caja o de sus componentes a Córdoba, para ser decorada allí. Agradezco a M. Vendrell su amabilidad en proporcionarme copia de este trabajo.

108 Sin embargo, el mobiliario sacro está construido en madera de acacia: el Arca de la Alianza, la Mesa, el Altar, y el suelo y los travesaños del Tabernáculo.

109 B. REUDENBACH, "Reliquien von Orten. Ein frühchristliches Reliquiar als Gedächtnisort", B. REUDENBACH y G. TOUSSAINT (eds.), Reliquiare im Mittelalter, Berlín, 2011 (2a ed.) (Berlín, 2005), p 20. 
Todo ello suscita la siguiente pregunta: ¿se trata de madera importada o de una caja importada? La respuesta puede indagarse rastreando el origen del formato de cubierta en pabellón o pirámide truncada con larguero incorporado a la tapa ${ }^{110}$.

Por su fecha, la pieza de la Cámara Santa antecede a todos los ejemplares de orfebrería conservados, siendo estrictamente coetánea de la pieza astorgana, donada en el mismo entorno cortesano ovetense. Respecto a las piezas de marfil, las cajas carolingias son mucho menores, adoptan un formato vertical, y carecen de cubierta truncada y de tapa con larguero, por lo que pueden desecharse como antecedentes tipológicos. Las restantes arquetas de cubierta troncopiramidal son posteriores en siglos, y para las de producción en centros islámicos ${ }^{111}$ se ha postulado que el formato es importación cristiana, al interpretarse como transposición de los sarcófagos reales de piedra con similar tipo de cubierta en recipientes concebidos como contenedores de reliquias ${ }^{112}$. Si bien esta hipótesis puede ser cierta en lo referente a las piezas sicilianas, no se ajusta a los datos en las piezas de orfebrería, tanto cristianas como islámicas, donde el uso originario no tuvo nada que ver con la custodia de reliquias. Tampoco se aprecia relación alguna con los relicarios de bolsa, o crismales de la Europa de los siglos VII-IX, ni con las cajitas de marfil carolingias, ni los relicarios o estaurotecas del Imperio medio bizantino.

Este panorama permite deducir algunas conclusiones. En primer lugar, el tamaño excepcional de la Arqueta de las Ágatas: no hay entre las piezas orfebrísticas coetáneas ninguna otra que alcance su superficie $(42,5 \times 27 \mathrm{~cm})$. Entre las piezas de marfil, solamente es superada por cajas muy posteriores, como el arca de San Pelayo de San Isidoro de León ${ }^{113}$, la arqueta de la abadía de Melk ${ }^{114}$, o la de Sint Servaas de Maastricht ${ }^{115}$, con clara vocación relicaria. A la vez, entre estas cajas de tamaño grande, la ovetense es la más baja: ninguna ofrece un formato tan aplanado. En segundo lugar, la proveniencia del formato: ni en la Europa de los siglos VII-X, ni en el Bizancio coetáneo aparece el tipo de arqueta ancha con tapa ataudada o en pabellón con limatesas rebajadas. La estrictamente contemporánea de Astorga difiere en la proporción de la altura, y aún más la posterior de Gerona. En tercer lugar, el tipo de madera: la elección del ciprés, especie mediterránea, que contrasta con la madera de caducifolio

110 Para elaborar los párrafos que siguen se ha confeccionado un corpus de más de 100 cajas orfebrísticas y ebúrneas de ámbito insular, continental y mediterráneo, abarcando desde el s. VII al XII, que permite estadísticamente cierta seguridad en la extracción de las conclusiones.

111 Vid. sobre estas piezas: A. GALÁN Y GALINDO, Marfiles medievales del Islam, Córdoba, 2005, II, pp. 217-285; D. KNIPP (ed.), Siculo-Arabic Ivories and Islamic Painting 1100-1300, Munich, 2011.

112 A. GALÁN Y GALINDO, op. cit., 2005, II, p. 194.

113 J. FERRANDIS, Marfiles y azabaches españoles, Barcelona, 1928, pp. 148-150, lám. XLIII; J. WILLIAMS y D. WALKER, "Reliquary of St. Pelagius”, The Art of Medieval Spain..., op. cit., 1993, n 109, pp. 236-238; C. COSMEN ALONSO, “Arca de San Pelayo”, Maravillas de la España medieval, op. cit., 2001, no 87, p. 229.

114 M. PIPPAL, "Kasette", H. FILLITZ y M. PIPPAL, Schatzkunst. Die Goldschmiede- und Elfenbeinarbeiten aus österreichischen Schatzkammern des Hochmittelalters, Salzburgo-Viena, 1987, $\mathrm{n}^{\circ}$ 59, pp. 239-240.

115 J.-CH. KLAMMT, "Eichenkasten, mit Elfenbein belegt”, A. LEGNER (ed.) Ornamenta Ecclesiae, Colonia, 1986, III, H 20, pp. 98-99. 
propia del bosque atlántico y centroeuropeo empleada en la generalidad de los objetos reseñados procedentes de este ámbito geográfico en los que consta el dato.

La Arqueta de las Ágatas, como la de Astorga, careció de cierre. Por el contrario, todas las arquetas procedentes de centros de producción andalusíes o mediterráneos -sicilianos, suditálicos- cuentan con cierre, previsto en el proyecto original y de una notabilísima uniformidad técnica y tipológica. Se trata de herrajes que abrazan el objeto por el exterior, contribuyendo notablemente a su estabilidad estructural. El número de las piezas implicadas aumenta desde el s. X al XIII, hasta convertirse en verdaderos enrejados o emparrillados que envuelven caja y tapa por todos sus lados ${ }^{116}$. En consecuencia, en la pieza ovetense, la ausencia de cierre y la colocación interior de las bisagras, completamente ocultas por el revestimiento metálico, señala una tradición técnica completamente diferente. Funcionalmente, hay que excluir también cualquier relación con los relicarios de bolsa, objetos cerrados y destinados a no ser abiertos y con los demás contenedores de reliquias, bien dotados de cierres que garanticen el sellado del objeto.

Por último, la técnica de labra, común también con la arqueta de San Genadio, por talla y vaciado de dos bloques macizos, singulariza a falta de mayor información, a las dos piezas asturianas y habla a favor de la talla local, habiéndose importado la madera en bruto. Desde luego, aun admitiendo la importación de la caja, es imperativo afirmar que la inserción de las ágatas fue proyectada y ejecutada en el reino asturiano, pues no de otra manera puede explicarse la labra del encastre en forma de cruz en el plano superior de la tapa.

\subsection{El diseño arquitectónico}

Las proporciones de la caja asturiana se reducen grosso modo a una relación de 1 : $2 / 3: 1 / 3$ (100:62:39), siendo un objeto de marcada componente horizontal, como acabamos de ver ${ }^{117}$. No se ajustan a ninguna de las medidas fundamentales de los referentes bíblicos: el Arca de Noé (Gn, 6, 15: 300 x 50 x 30 codos) mantiene unas relaciones de $1: 1 / 6: 1 / 10$; el Arca de la Alianza (Ex, 25, 10:2,5 x 1,5 x 1,5 codos), 1: 2/3:2/3; el Templo de Salomón ( 2 Re, 6, 2: 60 x 20 x 30 codos) se reduce a 1: $1 / 3: 1 / 2$. No obstante, no deja de ofrecer posibilidades hermenéuticas a la elección del formato de la tapa, en pabellón, la descripción del arca de Noé incorporada por Beato en el libro II del Comentario al Apocalipsis. Esta se encontraba en su tercer piso "per quattuor angulos collecta, usque ad unum cubitum coarctatae mensurae sit consummata", es decir, remataba desde las cuatro esquinas reduciéndose en toda su superficie hasta unirse en un punto de la dimensión de un codo ${ }^{118}$. Se refiere con ello a una cubierta en pabellón, como la de la arqueta ovetense, que puede ser descrita efectivamente como una construcción de tres pisos: larguero de la caja, larguero de la

116 A. GALÁN Y GALINDO, op. cit., 2005, I, pp. 213-216.

117 La caja de Astorga ( $30 \times 19 \times 16 \mathrm{~cm}$ ) ofrece unas proporciones muy similares en cuanto a la relación longitud/anchura, pero la ratio de la altura es superior $(100: 63: 53)$.

118 BEATO DE LIÉBANA, op. cit., 1995, p. 274. La traducción (p. 275) no da razón de la idea expresada por el participio collecta, que aporta el sentido de totalidad. 
tapa y pabellón piramidal. Las ilustraciones del pasaje de los Comentarios al Apocalipsis parecen confirmar la idea, al representar secciones del arca, con cubierta a dos aguas y remate plano ${ }^{119}$, como si se quisiera aludir al remate central de una cubierta en pabellón concentrada en torno a un hueco de un codo de lado. En este sentido, resulta de interés la asimilación del Arca de la Alianza a la predicación del Evangelio y el perdón de los pecados anotada por Beato en el Comentario al Apocalipsis (Lib. VI) ${ }^{120}$.

Es moneda común referirse a los huecos de los cuatro laterales de la arqueta como arcos, describiéndose incluso como de herradura, peraltados o de medio punto según los casos. En realidad, una observación más atenta permite desechar cualquier voluntad de representar elementos de arquitectura. La caja de Astorga, la arqueta de San Isidoro de León (MAN), el cáliz de Santo Domingo de Silos, entre otras piezas, muestran series de arcos en cada uno de sus lados y en copa y pie, con específico reflejo de su diseño como forma arquitectónica (rosca, imposta, columna) ${ }^{121}$. La intención significativa puede ser diversa, y ha sido puesta en relación, en el caso de los cálices y las píxides, con la "arquitectura de salvación", que vincula iconológicamente la Fuente paradisíaca de la Vida, la pila bautismal y el Santo Sepulcro ${ }^{122}$. Nada de ello hay en la pieza ovetense. Tampoco las líneas que definen los planos y volúmenes de la arqueta han sido subrayadas con diseños arquitectónicos-impostas, cornisas, molduras diversas, almenas, estilóbatos, podios...-. Por el contrario, los campos decorativos existentes entre los huecos están ocupados con roleos vegetales, que derivan, bien del tallo o tallos plantados en el campo central o de los situados en los extremos, y las limatesas, bandas y esquineras están decoradas con motivos que derivan del repertorio de la plástica o la miniatura. Se deduce de ello que no ha existido en el ánimo del proyectista voluntad alguna de configurar un objeto arquitec-

119 Cf. Beato de Tábara-Escalada, fol. 79 (J. WILLIAMS, The Illustrated Beatus, vol. 3. The tenth and eleventh centurias, Londres, 1998, ill. 40); Beato de Valcavado, fol. 73v (ibid., ill. 167); Beato de Tábara (Gerona), fol. 102v-103 (ibid., ill. 312).

120 "Et visa est arca testamenti in Templo eius. Evangelii praedicatio est, et indulgentia peccatorum". BEATO DE LIÉBANA, op. cit., 1995, p. 466.

121 Lo mismo puede predicarse de otras muchas piezas provenientes de los más dispares contextos históricos: píxides marfileñas tardoantiguas, como la conservada en los Staatliche Museen de Berlín (W.F. VOLBACH, Elfenbeinarbeiten der Spätantike und des frühen Mittealters, Maguncia, 1976, n 257); los cálices del tesoro de Kaper Koraon, del s. VI (M. MUNDELL MANGO, Silver form Early Byzantium. The Kaper Koraon and related Treasures, Baltimore, 1986, pp. 74-77); el cáliz del obispo Lebuinus, con una composición sintética de tholos sobre cuatro columnas y canceles intermedios (V.H. ELBERN, Der eucharistiche Kelch im frühen Mittelalter, Berlín, 1964, pp. 19-21 y 124-132); el cáliz del duque Tassilo de Baviera, de fines del VIII (ibid., p. 14); el reverso del relicario de Enger, de fines del VIII; el relicario de Pipino, del Tesoro de Sainte-Foi de Conques; la píxide carolingia de Fejø (Nationalmuseet, Copenhague) (E. WAMERS, op. cit. (1991), pp. 117-123); el incensario de Split, procedente probablemente de Salzburgo (Muzej Hrvastkih Arheoloskih Spomenika) (E. WAMERS, "Liturgisches Gerät", M. BRANDT y E. WAMERS (eds.), Die Macht des Silbers. Karolingische Schätze im Norden, Regensburg, 2005, pp. 86-91); la amplia serie de altares portátiles románicos, que abre el altar portátil de Gertrudis, del tesoro de los Güelfos, ca. 1040 (The Cleveland Museum of Art) (H. WESTERMANN-ANGERHAUSEN, "Die Stiftungen der Gräfin Gertrud-Anspruch und Rang”, J. EHLERS y D. KÖTZSCHE (eds.), Der Welfenschatz und sein Umkreis, Maguncia, 1998, pp. 51-76, esp. 55-58), y los tipológicamente emparentados relicarios tumbales colonienses del último tercio del XII.

122 V.H. ELBERN, op. cit., 1964, pp. 97-123, esp. 117-123; E. WAMERS, op. cit. (1991), p. 128. 
tónico y que por ello está lejos de su intención la aplicación a la caja de cualesquiera resonancias iconológicas derivadas del inexistente modelo.

El diseño de la tapa ofrece significativos paralelos con las encuadernaciones otonianas de evangeliarios y sacramentarios. Comparte con ellas la presencia de una placa central cruciforme, que estructura el sentido de la pedrería y las líneas de fuerza de la composición, combinada con un esquema de aspa ${ }^{123}$. Los ejemplos más cercanos son: la cubierta del evangeliario conocido como Codex Aureus de Echternach (Germanisches Nationalmuseum, K.G. 1138, Nuremberg), datado entre 983 y 991, y promovido por la emperatriz Theophanu en su regencia durante la minoría de Otón III ${ }^{124}$; las dos cubiertas del evangeliario Cod. Guelf 46 Helmst (Herzog-August Bibliothek, Wolfenbüttel), de principios del XI y obra del círculo formado en torno a Bernward de Hildesheim, con el interesante paralelo de su decoración vegetal repujada ${ }^{125}$; y la cubierta del evangeliario de la abadesa Theophanu (Domschatz, Essen), de la primera mitad del XI ${ }^{126}$.

Puede ser completada la serie con una variante que incorpora una placa central sobre esquema de cruz: cubierta del evangeliario conocido como Codex Aureus de Sankt Emmeram de Ratisbona (Bayerisches Staatsbibliothek, Cod. Lat. 14000, Cim. 55, Munich), del 870 ${ }^{127}$; cubierta del evangeliario de San Gauzelin (Catedral, Nancy), del último tercio del s. $\mathrm{X}^{128}$; cubierta del evangeliario de Morienval (Catedral, Noyon), del s. $\mathrm{X}^{129}$; cubierta del evangeliario de Bamberg (Bayerisches Staatsbibliothek, Cod. Lat. 4454, Cim. 59), de principios del s. XI ${ }^{130}$; cubierta del evangeliario áureo (Domschatzkammer, Aquisgrán), del mismo momento ${ }^{131}$; cubierta del evangeliario de Helmarshausen (Domschatz, Nr 68, Tréveris), fechado hacia $1100^{132}$; y la cubierta del misal de Berthold (John Pierpont Morgan Library, M 710, Nueva York), el más tardío, datado ca. 1210-1220133.

Se ha conservado una caja de orfebrería destinada a albergar un evangeliario: la caja del denominado Uta-Kodex (Bayerische Staatsbiblithek, Cim. 13601, Munich), perteneciente a la abadesa Uta de Niedermünster, Ratisbona/Regensburg, fechada hacia 1020, con una importante alteración del marco producida a principios del XIII.

123 F. STEENBOCK, Der kirchkliche Prachteinband im frühen Mittelalter, Berlín, 1965, pp. 26-27, fig. 20.

124 Ibid., ${ }^{\circ}$ 42, pp. 119-121, Abb. 60.46 x 30,5 cm. La placa de marfil está fechada en el primer cuarto del XI y se considera introducida en sustitución de otra perdida o dañada.

125 Ibid., $\mathrm{n}^{\mathrm{o}} 48$, pp. 128-129, Abb. 66-67. 28,5 x 20,5 cm.

126 Ibid., nº 62, pp. 152-154, Abb. 86. 35,7 x 26 cm. A. PAWLIK, "Buchdeckel des Theophanu-Evangeliars", B. FALK (ed.), Gold vor Schwarz. Der Essener Domschatz auf Zollverein, Essen, 2008, pp. 82-85.

127 F. STEENBOCK, op. cit., 1965, nº 20, pp. 90-92, Abb. 32. 42 × 33 cm; O.K. WERCKMEISTER, Der Deckel des Codex Aureus von St. Emmeram. Ein Goldschmiedewerk des 9. Jahrhunderts, Baden-BadenEstrasburgo, 1963.

128 F. STEENBOCK, op. cit., 1965, nº 29, pp. 105-107, Abb. 44-45. 30,5 x $22 \mathrm{~cm}$.

129 Ibid., n ${ }^{\circ} 37$, pp. 114-115, Abb. 54-55. 24,5 x 19,3 cm.

130 Ibid., no 47, pp. Abb. 65; H. FILLITZ, "Sakramentar-Einband", M. BRANDT (ed.), Bernward von Hildesheim und das Zeitalter der Ottonen, Hildesheim-Maguncia, 1993, II, nº II-45, pp. 103-104. 30,5 x 23,6 $\mathrm{cm}$.

131 F. STEENBOCK, op. cit., 1965, no 51, pp. 133-135, Abb. 72. 30,8 x 23,7 cm.

132 Ibid., $\mathrm{n}^{\circ} 79$, pp. 171-173, Abb. 107. 37 x $25 \mathrm{~cm}$.

133 Ibid., nº 116, pp. 215-217, Abb. 158. 29,8 x 20,8 cm. 
Mide 44,3 x 32,5 x 8,9 cm y fue confeccionada específicamente para este Evangeliario ${ }^{134}$. El parecido en concepto y dimensiones, que hace plausible la comparación, despierta a su vez una nueva pregunta, sobre la razón de la inexistencia de encuadernaciones orfebrísticas en la Hispania medieval. No cabe acudir al argumento de la destrucción o desaparición, que exigiría a su vez una explicación de este singular comportamiento frente a la Europa coetánea. De hecho, aunque raras, se pueden citar algunas referencias documentales a encuadernaciones orfebrísticas altomedievales en la Península Ibérica: así, la donación del templo de San Salvador al monasterio de Santa María de Ripoll, por parte del conde Suñer, fechada el 25 de marzo de 925, en la que se cita un "textum evangelium cohoperto de argento paratum de auro..." 135 .

\subsection{Las tradiciones técnicas del revestimiento metálico y la aplicación de las ágatas}

Se trata de lámina de oro recortado y repujado. No hay filigrana, ni apliques soldados a la lámina de oro, ni esmaltes. La unidad de la lámina de cada panel solamente se ve alterada por los cordones que rodean cada uno de los huecos y los que delimitan las tiras de engaste de la pedrería. Los engastes son todos de caja simple lisa, con cordón perimetral torso en la base, mayoritariamente de contorno ovalado, y en menor medida rectangular. No aparecen los engastes en artesa ni los de celdillas de filigrana aérea ni los turriformes para las perlas de la Cruz de la Victoria ${ }^{136}$.

El repujado no se emplea en las tres cruces asturianas, pero es la base de la decoración del revestimiento metálico de la Arqueta de Astorga. En todo caso, conceptualmente, los motivos de ambas cajas difieren en diseño e iconografía (tallos de palmas y palmeras en Oviedo frente a árboles y ángeles en Astorga), por lo que apenas se puede hablar de parentesco entre ambas en este aspecto. Solamente la arqueta ovetense emplea el calado para mostrar la dotación de ágatas. No existe la filigrana decorativa, esencial en la configuración decorativa de las tres cruces, ni se aplican elementos soldados a la lámina, salvo los cordones de hilo perlado y torso que delimitan los paneles, los huecos calados y las tiras de engastes. Tampoco se han incorporado elementos ajenos a la propia lámina, como los anillos de cordones de perlas ensartadas del reverso de la Cruz de los Ángeles, la placa esmaltada del anverso de la Cruz de Santiago, las celdillas esmaltadas de los largueros de la Arqueta astorgana, o las plaquitas esmaltadas y las bandas sobreelevadas de pedrería en los brazos del anverso de la Cruz de la Victoria. La caja carece de elementos de glíptica reutilizados, presentes en las cruces. En este sentido, resulta patente que el concepto decorativo del autor de este revestimiento metálico es completamente independiente de los que se pusieron de manifiesto en la restante orfebrería asturiana.

Pese a que la conservación de la coetánea orfebrería andalusí ha sido muy deficiente, los ejemplos conocidos permiten establecer alguna comparación. Así, la diadema

134 H. FILLITZ, “Ottonische Goldschmiedekunst”, M. BRANDT (ed.), op. cit., 1993, I, p. 189; F. STEENBOCK, op. cit., 1965, n 59, pp. 147-149, Abb. 79.

135 R. ORDEIG I MATA, Les dotalies de les esglèsies de Catalunya (segles IX al XIII), Vic, 1993, I, nº 46, pp. 115-116.

136 H. SCHLUNK, op. cit., 2008, pp. 93-94. 
o ceñidor del tesoro de Charrilla (Jaén, Museo Arqueológico Provincial), fechado entre 944 y $947^{137}$, ofrece la combinación de engastes sobre lámina de oro repujada con tema vegetal, y una coronación formada por triángulos, semejante a la de la tapa de la arqueta astorgana. No obstante, los botones troquelados y soldados ceñidos por hilo torso faltan en la pieza ovetense. Apenas nada común se puede apreciar, sin embargo, en los ejemplos conservados de orfebrería taifa, como el tesoro de Lorca (Victoria and Albert Museum, Londres) o el conservado en The Walters Art Gallery, Baltimore, que responden a otras tradiciones técnicas, dominadas por el empleo de la filigrana ${ }^{138}$.

Por el contrario, el repujado es técnica abundantemente empleada en la orfebrería pleno y tardocarolingia. Muestra de la primera es la serie de píxides eucarísticas en plata, fechadas en torno a las décadas de 820-830, procedentes de talleres francos y recuperadas por hallazgos casuales en tierras de ocupación vikinga. Destacan en especial en las producciones tardías las cubiertas de evangeliarios que hemos citado, ejemplo patente de ello: la cubierta del Codex Aureus de Sankt Emmeram de Ratisbona (870), la coetánea cubierta anterior del Evangeliario de Lindau (J.P. Morgan Library, Nueva York), y la tercera de las piezas del círculo orfebrístico agrupado en torno a Carlos el Calvo, y activo en Reims, el ciborio de Arnulfo de Carintia (Schatzkammer der Residenz, Munich) ${ }^{139}$. A ellas se añade la caja de Ellwangen, también fechada hacia 876-886 (Stuttgart, Württembergisches Landesmuseum) ${ }^{140}$. En todas estas piezas se cuenta con iconografía figurativa e historiada. Una generación más tarde, en torno a los años 890-910, se confeccionó en Sankt Gallen la encuadernación del Evangelium longum, a cargo del monje Tuotilo, que está dotada en las cenefas perimetrales de motivos vegetales repujados con gran relieve ${ }^{141}$. No obstante, ni estilísticamente ni iconográficamente se puede apreciar parentesco alguno entre estas piezas francas y la arqueta ovetense.

\subsection{El sentido de la pedrería: número, selección, distribución y combinación de las} piedras

La primera y fundacional dotación de pedrería de la arqueta son las 91 láminas de ágata que, convenientemente recubiertas por los paneles de oro, ofrecen una serie de 99 huecos. La cifra no es casual. Noack-Haley reparó en el paralelo que ofrecen las 99 estrellas del mosaico absidal de Sant'Apollinare in Classe, Rávena, en relación con la contracción numerológica de la aclamación Amén en alfabeto griego (AMHN $=1+40+8+50)$, lo que sitúa las placas en un contexto de alabanza eterna apocalíptica (Ap. 19,4) ${ }^{142}$. No obstante, han sido propuestas otras vías exegéticas. A propósito

137 J. ZOZAYA, "Diadema o ceñidor del tesoro de Charrilla", J.D. DODDS (ed.), Al-Andalus. Las artes islámicas en España, Madrid, 1992, nº 17, p. 220.

138 J. ZOZAYA, "Par de arracadas", J.D. DODDS (ed.), op. cit., 1992, n 18, p. 221, y "Elementos de joyería", ibid., no 19 , pp. 222-223.

139 V.H. ELBERN, Die Goldschmiedekunst im frühen Mittelalter, Darmstadt, 1988, pp. 79-91.

140 Ibid., p. 64, Abb. 40-41.

141 F. STEENBOCK, op. cit., 1965, nº 23, pp. 98-100, Abb. 36-37.

142 S. NOACK-HALEY, op. cit., 1993, p. 145, sobre F.W. DEICHMANN, Ravenna. Hauptstadt des spätantiken Abendlandes. II. Kommentar, Wiesbaden, 1989, p. 256. La interpretación de Deichmann ya había 
del mismo mosaico, Dinkler se ha referido a la homilía de Cirilo de Jerusalén (De secundo Christi adventu), según la cual el número se refiere a los 99 ángeles que acompañan la Parusía, en exacta equivalencia a los 99 ovejas de la parábola evangélica, en cuyo contexto la Humanidad corresponde al restante justo por el que se inmola Cristo $(\mathrm{Mt}, 18,12)$. No fue el obispo palestino el único que hubo interpretado así la cifra y su contexto. Con el mismo sentido figura en la Homilia in Resurrectionem Christi, de Epifanio de Salamina, en el De remissione peccatorum de San Juan Crisóstomo, y en el Commentarius in Psalmos (in Ps 18,6) de Orígenes. La referencia a la misma parábola está en el Comentario al Apocalipsis de Ecumenio, aplicada precisamente al mismo pasaje joánico ${ }^{143}$.

A la vez, 99 es el producto de 3 x 33, la Trinidad multiplicando la edad de Cristo encarnado. Confiesa Dinkler que no existen testimonios documentales de esta última exégesis ${ }^{144}$.

La presencia de ágata como piedra monográfica en el equipamiento de una pieza de orfebrería es excepcional en la Alta Edad Media hispánica. De hecho, solamente se conocen los paralelos de la arqueta de San Isidoro de León, hoy en el Museo Arqueológico Nacional, Madrid, perteneciente a la gran donación de Fernando I y Sancha, fechada en la primera mitad del XI, que cuenta con 57 huecos que traslucen ágatas de superficie plana y abombada ${ }^{145}$, y del cáliz de Doña Urraca de la misma colegiata, de fines del XI, que reemplea dos piezas tardoantiguas en base y copa, ensambladas mediante rica armadura de oro ${ }^{146}$. Sin embargo, se conocen más piezas comparables a esta última en el empleo de copas de ágata. Así, el denominado cáliz de San Adalberto, proveniente de la colegiata de Trzemeszno (Museum Archidiecezjalne, Gniezno), con copa de ágata, obra bizantina del X, en marco de oro elaborado en el XVIII ${ }^{147}$; la serie de cálices y patenas del período bizantino medio del Tesoro della Basilica di San Marco, Venecia, que reutilizan tazas tardoantiguas talladas en

sido ofrecida por E. DINKLER, Das Apsismosaik von Sankt Apollinare in Classe, Colonia-Opladen, 1959, p. 64, n. 112, apoyado a su vez en A. STUIBER, “Amen", Jahrbuch für Antike und Christentum, I (1958), pp. 153-159 (Reallexikon für Antike und Christentum, SuppBd. 1 (2001), pp. 310-323). La misma intención parece evidente en los tres coros de 33 niños (schola cantorum) con que contaban los oficios litúrgicos de Saint-Riquier-Centula, destinados al laus perennis, según el Chronicon Centulense, II, 3, de Hariulfo. Cf. C. HEITZ, La France préromane. Archéologie et architecture religieuse du Haut Moyen Âge du IV́a siècle à l'an Mil, París, 1987, p. 140. Texto en J. VON SCHLOSSER, Schriftquellen zur Geschichte der karolingischen Kunst, Hildesheim-Zürich-Nueva York, 1988 (2 ed.), nº 784, p. 260.

143 ECUMENIO, Comentario al Apocalipsis, X, 7.1 (trad. L.F. MATEO-SECO, Madrid, 2008, p. 215). Vid. para las referencias patrísticas mencionadas, la edición citada de Mateo-Seco, p. 215, n. 9.

144 E. DINKLER, op. cit., 1959, p. 64, n. 112. No obstante, ha de tenerse en cuenta el programa completo del mosaico ravenaico, que no es otro que la Transfiguración, habiendo sido sustituida la figura de Cristo por la de la cruz parusíaca dotada de medallón cristóforo en el centro.

145 A. FRANCO MATA, Arte leonés (siglos IV-XVI) fuera de León, León, 2010, p. 41.

146 V.H. ELBERN, op. cit., 1964, n 19, p. 71; Á. FRANCO MATA, "El Tesoro de San Isidoro y la monarquía leonesa", Boletín del Museo Arqueológico Nacional, IX (1991), pp. 63-64.

147 P. SKUBISZEWSKI, "Sog. Adalbertkelch aus Tremessen (Trzmeszno)", M. BRANDT (ed.), op. cit., 1993, II, no II-34, pp. 82-83; H. KOČKA-KRENZ, "So gennanter Kelch des heiligen Adalberts", A. WIECZOREK y H.-M. HINZ (eds.), Europas Mitte um 1000, Stuttgart, 2000, nº 19.02.13, p. 419. 
piedras preciosas ${ }^{148}$; incluyendo el gran cáliz del emperador Romano I (920-944) ${ }^{149}$; la naveta eucarística del tesoro de Saint-Denis, (Bibliothèque Nationale, Cabinet des Médailles, París), de principios del s. XI ${ }^{150}$; la patena de mediados del s. X conservada en una colección privada suiza ${ }^{151}$; la copa gallonada del Musée du Louvre (Dep. des Objets d'art, E.271), de los siglos X-XI ${ }^{152}$; y la copa de pie alto del Metropolitan Museum of Art (17.190.594), genéricamente datada en los siglos X-XII ${ }^{153}$, entre otras muchas ${ }^{154}$. Es evidente que la producción de un objeto suntuario con ágata conlleva un componente de emulación imperial, con el explícito deseo de igualar la calidad y el lujo bizantinos, patente explícitamente en la confección del cáliz por parte de Suger de Saint-Denis ${ }^{155}$.

La reconstrucción del orden cromático original de la pedrería engastada resulta muy difícil, habida cuenta de las pérdidas sufridas por la arqueta a lo largo de su historia y de la reposición aleatoria/“estética" de la misma en la reconstrucción tras 1977. No obstante, el recuento y síntesis de las descripciones de cada una de las 88 piedras consideradas originales arroja los siguientes resultados, agrupados por colores y especies minerales ${ }^{156}$.

1. Incoloro: zafiro (10), cuarzo $(15,139)$, vidrio $(23,93)$, ópalo (190).

2. Blanco: cuarzo-calcedonia $(21,92)$, ópalo (53).

148 V.H. ELBERN, op. cit., 1964, pp. 20-21 y 39, Abb. 38; K. SCHULMEYER: "Byzantinische Kelch", “Patene", A. WIECZOREK y H.-M. HINZ (eds.), op. cit., 2000, n 02.03.06, 02.03.07, 02.03.08, y 02.03.09, pp. 31-33; e I. KALAVREZOU, "Chalice with Eucharistic Inscription", The Glory of Byzantium..., op. cit., 1997, no 32, p. 71. Cf. H.-R. HAHNLOSER (ed.), Il Tesoro di San Marco. 2. Il Tesoro e il Museo, Florencia, 1971.

149 I. KALAVREZOU, “Chalice of Emperor Romanos”, The Glory of Byzantium..., op. cit., 1997, n 31, p. 71.

150 D. GABORIT-CHOPIN, "Les arts précieux en l'an Mil”, P. RICHÉ (dir.), L'Europe de l'An Mil, Orléans, 2001, p. 357, pl. 163.

151 H.C. EVANS, "Paten", The Glory of Byzantium..., op. cit., 1997, n 28, pp. 67-68.

152 D. KATSARELIAS, "Hard-Stone Fluted Cup", The Glory of Byzantium..., op. cit., 1997, n 177, p. 252.

153 D. KATSARELIAS, "Hard-Stone Cup", The Glory of Byzantium..., op. cit., 1997, n 178, pp. $252-253$.

154 La frecuencia con que en la Antigüedad grecorromana se utilizaron piezas de ágata para labrar vasos fue la causa de que esta función despertara posibilidades exegéticas en la patrística. Epifanio de Salamina (De Gemmis) interpretó el ónice como símbolo de San Pablo, antitipo de Benjamín, aplicándole el concepto de "vaso elegido de la Iglesia". Cf. CH. MEIER, Gemma spiritalis. Methode und Gebrauch der Edelsteinallegorese von frühen Christentum bis ins 18. Jahrhundert. Teil I, Munich, 1977, p. 491, n. 1891. La relación tipológica entre Pablo y Benjamín en este caso se apoya en una doble raíz: por un lado son los últimos de las series duodecimales de patriarcas y apóstoles; por otro, la historia de Benjamín le hace ser depositario de la copa de José, introducida subrepticiamente en su bagaje (Gn. 44, 2-12). José es interpretado como el conjunto del pueblo elegido (Abd. 18) y su copa, por ello, tipológicamente, es signo de la copa de la Iglesia. En consecuencia, Benjamín es el depositario de la copa elegida, y Pablo, su antitipo, lo es del mismo modo y puede por ello ser asimilado al ónice. Cf. A. COLUNGA y L. TURRADO, "Index biblicus doctrinalis", apud Biblia Vulgata, Madrid, 1985 ( $8^{\mathrm{a}}$ ed.), p. 1216, s.v. Ioseph. No obstante, es preciso tener presente que la obra de Epifanio de Salamina no fue conocida en Occidente, salvo breves citas en Jerónimo, hasta el s. XVI. Cf. CH. MEIER, op. cit., 1977, p. 508.

155 W.D. WIXOM, "Chalice of Abbot Suger of Saint-Denis", The Glory of Byzantium..., op. cit., 1997, $\mathrm{n}^{\mathrm{o}} 296, \mathrm{pp} .457-458$.

156 La numeración corresponde a la establecida en el dibujo del referido trabajo de C. ÁLVAREZ DE BENITO, op. cit., 2002a, p. 421. 
3. Naranja: coral $(26,71,73,152,177)$, cuarzo-calcedonia $(60,112,175,199)$, ópalo (114).

4. Rojo: vidrio $(16,91,113,127,162,183,194)$, granate $(76,80,83,97,99,103,106$, $107,124,128,145,164,171,173,195,208,217,220)$.

5. Marrón: coral $(30,45)$, ópalo $(221)$.

6. Verde: vidrio $(29,34,54,56,90,95,98,111,169,174,176,209)$, berilo (160).

7. Azul: vidrio $(14,19,32,35,37,47,50,57,88,100,138,140,148,203,207)$, cerámica $(85,104,119,153,165,224)$, zafiro $(137,189)$.

8. Morado: vidrio $(13,89,131)$, amatista (46).

9. Negro: vidrio (122).

A la vista salta que, con mucha diferencia, el vidrio predomina abrumadoramente entre los cabujones originales: $41 / 88$ (46,6 \%); le siguen los granates almandinos: 18/88 (20,4 \%); los cuarzos: 8/88 (9,1\%); los corales: 7/88 (8\%); las cerámicas: 6/88 (6,8 \%); los ópalos: 4/88 (4,6\%); los zafiros: 2/88 (2,3\%); la amatista: 1/88 (1,1\%); y el berilo: $1 / 88(1,1 \%)$. Concluimos que de lo conservado de la dotación original de pedrería $(88 / 224 ; 39,2 \%$ ), más de la mitad son piezas sin valor material (vidrios y cerámicas, $53,4 \%$ ), más de un tercio $(37,5 \%$ ), piedras semipreciosas (cuarzos, corales, granates), y solamente el 9,2\% piedras preciosas (ópalos, zafiros, amatista y berilo).

Ateniéndonos a estos resultados, cabe exponer como la posible causa de esta selección la propia evolución histórica de los expolios de la pedrería, interesada lógicamente en extraer aquellas piezas valiosas, lo que ha conducido a la pérdida casi total de la dotación preciosa originaria, mientras que los cabujones sin valor han sobrevivido sin mayor afección. La muestra conservada, en consecuencia, está estadísticamente sesgada y carece de toda potencialidad informativa para la reconstrucción del equipamiento originario. La conclusión me parece inamovible. Aún podemos extraer otra conclusión, relativa a la cualidad mineralógica de las piezas responsables de los colores conservados. En efecto, el rojo se ha conservado solamente en granates y vidrios, habiendo desaparecido - si es que existieron- todas las piedras preciosas rojas (rubí, sardio, topacio); el azul solamente se ha conservado en un zafiro, consistiendo el resto de cabujones en vidrios y cerámicas; el verde existente consiste en vidrios salvo un único berilo, y no sabemos por ello si se contó con alguna esmeralda; el naranja/marrón solamente cuenta con piedras semipreciosas (cuarzo, coral) y dos ópalos: ni un solo topacio; el morado enfrenta una única amatista a tres vidrios; por último, las piedras blancas o incoloras parecen haberse salvado en mayor proporción del expolio, pues conservamos tres piedras preciosas, cuatro cuarzos y dos vidrios. Es patente que el expolio ha sido intencional y se ha cebado en las piezas teóricamente más representadas, como las rojas (rubíes), verdes (esmeraldas) y azules (zafiros).

Esta constatación, empero, no impide el planteamiento de la siguiente cuestión, a saber: la validez de la muestra para la reconstrucción del orden cromático en términos exclusivamente cuantitativos, no en términos locacionales.

Se cuenta de este modo con la siguiente elección de colores: incoloro: $6 / 88(6,8$ \%); blanco: 3/88 (3,4 \%); naranja: 10/88 (11,3\%); rojo: 25/88 (28,3\%); marrón: 3/88 (3,4 \%); verde: 13/88 (14,7 \%); azul: 23/88 (26,1 \%); morado: 4/88 (4,6 \%); negro: $1 / 88(1,1 \%)$. Es claro el predominio del rojo y el azul, superiores al $25 \%$ cada uno, 
seguidos por el verde y el naranja/marrón (14,7 \% cada uno), siendo los restantes colores meramente testimoniales. Este resultado, que considero estadísticamente válido, pues es lícito pensar que las cantidades conservadas de vidrios y otros cabujones sin valor responden a la proporción inicialmente observada, permite adscribir el orden cromático cuantitativo de la arqueta a la norma de su tiempo. Efectivamente, de las investigaciones de Gerda Friess y Theo Jülich se concluye la existencia de tres órdenes cromáticos sucesivos en la Antigüedad Tardía y la Edad Media. El primero, propio de la Antigüedad Tardía, se compone de la combinación azul-verde-blanco; el segundo, que ya aparece igualmente en la Antigüedad Tardía, caracteriza el período altomedieval, consiste en rojo-azul-verde-blanco; y el tercero, a partir del s. XI, añade el dorado (topacio) al orden precedente. El fundamento está en la reserva imperial de uso de zafiros, esmeraldas y perlas establecida por León I (457-474), que completa la reserva del color púrpura decretada de antiguo, lo que pudo indudablemente reservar el uso del rubí y la amatista para los objetos exclusivamente imperiales ${ }^{157}$. Por el contrario, el topacio, inexistente antes del año 1000 en la joyería regia, aparece con fuerza en piezas e iconografía de los siglos XI y XII, probablemente por influjo de la exégesis bíblica, donde su presencia es constante ${ }^{158}$.

Una vez repuesta a sus engastes originarios por los restauradores la pedrería considerada original o antigua conservada de la Arqueta de las Ágatas, en la medida en que contaron con base documental suficiente, no es posible reconstruir de ninguna manera el orden cromático original, salvo en la placa superior. Aquí se hace patente: cruz de cuatro grandes piedras rojas (Pasión), con cabujón central transparente (Cristo), cuatro piedras azules en las esquinas (los ríos del Paraíso) y cuatro perlas intermedias (los cuatro Evangelistas, de los que brotan los ríos paradisíacos). Desgraciadamente, no se ha conservado ninguna serie de cabujones en sus engastes originales en número suficiente como para permitir la extrapolación del ritmo cromático.

Las tiras y limatesas muestran gran uniformidad en el calibre de los engastes, muy limitados por la anchura de las bandas metálicas. Su distribución es totalmente simétrica en los cuatro frentes de la tapa, apreciándose estricta correspondencia entre las posiciones de los engastes de los bordes superior e inferior del larguero. No se mantiene la correlación entre estas series y el borde inferior del larguero de la caja, como resulta previsible a partir del diferente número de piezas colocadas. Tampoco se advierte ritmo alguno en el reparto de los formatos rectangulares u ovalados de los engastes de cada tira. Por el contrario, en los paneles de la tapa, a la ya observada simetría de colocación se añade la simetría en el calibre y en el formato rectangular u ovalado de los engastes, que se corresponden en relación especular dos a dos entre paneles principales y paneles laterales. Sin embargo, en la correspondencia cromática

157 G. FRIESS, Edelsteine im Mittelalter. Wandel und Kontinuität in ihrer Bedeutung durch zwölf Jahrhunderte (in Aberglauben, Medizin, Theologie und Goldschmiedekunst), Hildesheim, 1980, pp. 55-74; TH. JÜLICH, "Gemmenkreuze. Die Farbigkeit ihrer Edelsteinbesatzes bis zum 12. Jahrhundert", Aachener Kunstblätter, 54-55 (1986-1987), pp. 99-258, esp. 120-130; y A. ALFÖLDI, "Insignien und Tracht der römischen Kaiser”, Die monarchische Repräsentation im römischen Kaiserreiche, Darmstadt, 1970 (3ª ed.), p. 168.

158 G. FRIESS, op. cit., 1980, pp. 68-73. 
no se aprecia simetría alguna ni entre las bandas horizontales de los largueros entre sí, ni entre las limatesas ni entre los paneles de la tapa.

El equipamiento de pedrería de la arqueta se resume en 120 piedras de la tapa y 104 piedras de la caja. Es fácil descomponer la cifra en varias combinaciones con resonancias numerológicas. Así, la cifra resulta de sumar $(2 \times 12)+(2 \times 100)$. Pero también se pueden aislar tapa y caja, 120 y 104 respectivamente.

La numerología altomedieval hispánica depende en su totalidad del libro III, De mathematica, cap. 1-9, de las Etymologiae de Isidoro. Beato la extracta y desarrolla en el Libro IV y en el Libro XII del Comentario al Apocalipsis, a propósito de la Jerusalén celeste ${ }^{159}$. En el caso concreto del 120 (duodecies decem), existen dos poderosas razones para su consideración. En primer lugar, el plazo de penitencia establecido antes del Diluvio, 120 años $(\mathrm{Gn}, 6,3)^{160}$. En segundo lugar, las 120 almas sobre las que descendió el Espíritu en Pentecostés, que significan la primera Iglesia (Act, 1, $15)^{161}$ y el conjunto de todos los creyentes en el tiempo de la Encarnación ${ }^{162}$. Estos 120 sumados a los 24 Ancianos de la corte celestial suman 144, cifra que compone a su vez el cuadrado de $12^{163}$ :

"Verum quia per numerum diximus, et per senarii numeri perfectionem esse explanavimus, nunc de senario duplicato XII fiunt. Haec est ecclesia in duodenario numero constituta, id est, apostoli: et duodecies ducti CXLIIII sunt" ${ }^{164}$.

En suma, "in duodenario numero Ecclesia constructa"165, pues "ter quaternum duodecim fiunt, Trinitatis mysterium quatuor mundi partes suscepisse significant"166.

$\mathrm{Al}$ margen de esta interpretación de fundamento bíblico, la elección del 120 como cifra que configura las series de pedrería de la orfebrería altomedieval posee otra raíz, derivada de un sistema de cálculo de base duodecimal, que se ha conservado en el mundo contemporáneo en el habitual cómputo por docenas de algunos artículos. Parte de las lenguas germánicas conservan un sustantivo para el 120, Grosshundert en alemán, storhundret en danés, y stort hundre en noruego, pero inexistente en sueco. En el dialecto antiguo nórdico (altnordisch) se emplea el numeral para 100 (hundraP) con el valor de 120. La cuestión responde a la misma razón que explica la singularidad de la formación de los numerales 11 y 12 en el mismo grupo lingüístico indoeuropeo. Se trata de un desplazamiento del umbral de las decenas, del 100 al 120, por el mismo procedimiento creativo que hizo surgir el 11 y el 12 una vez rebasada la decena. El fenómeno es de formación tardía y limitado al gótico y al antiguo nórdico,

159 BEATO DE LIÉBANA, op. cit., 1995, p. 640.

160 Ibid., p. 380.

161 Ibid., p. 406. Cf. pp. 544-546: Ubi ergo inchoavit Ecclesia, niis ubi venit de caelo Spiritus Sanctus, et implevit uno loco sedentes centum viginti? Duodenarius ille numerus duplicatus erat. Si per singulos duodecim denos ponas, qui perfectus est numerus, centum viginti fiunt.

162 ECUMENIO, Comentario al Apocalipsis, XI, 10 (Ed. Mateo-Seco, p. 237).

163 BEATO DE LIÉBANA, op. cit., 1995, p. 642.

164 Ibid., p. 406.

165 Ibid., p. 470. Cf. p. 638: Duodecim vero portae, et duodecim tribus Israel, duodecim Apostoli sunt, et XII Prophetae; quae est Ecclesia in duodenario numero constituta et firmata.

166 BEATO DE LIÉBANA, op. cit., 1995, p. 640. 
pues no consta en los restantes dialectos, por lo que puede excluirse su presencia en el germánico primitivo ${ }^{167}$.

En el caso de una pieza como la ovetense, tan definida teológicamente en su diseño, no parece razonable a priori indicar esta ascendencia. No obstante, la masiva y recurrente presencia del 12 y del 120 en sectores tan diferentes de la vida social germánica como la mitología, la literatura profana, la ordenación del calendario, las instituciones jurídicas y políticas y la agrupación -real o ficticia- de las unidades de poblamiento ${ }^{168}$, no deja de llamar la atención, y sugerir un repaso a los diversos campos de la vida institucional del reino de Asturias en los que pudiera detectarse el fenómeno.

Sobre el sentido del número 104 hemos de señalar su coincidencia con el número de perlas de la cubierta del Codex Aureus de Sankt Emmeram de Ratisbona. La descomposición en $4+100$ remite nuevamente a cifras redondas y perfectas.

\subsection{El destino inicial}

Gómez Moreno indicó como destino inicial de la caja astorgana, en la que veía "puntos de analogías muy grandes" con la asturiana, la reserva eucarística ${ }^{169}$. No obstante, en el capítulo que dedica en general a las preseas eclesiásticas, se refiere a las capsas, de uso general en los templos y presentes en casi todas las donaciones dotacionales, comentando que

“verosímil parece que sirvieran para la reserva eucarística; tardíamente consígnase respecto de algunas cajas su destino para reliquias, y otra contenía los Evangelios, dato que permite asimilar a ella los superevangeliares metálicos citados algunas veces" 170 .

Cuesta y Díaz Caneja propusieron la de relicario ${ }^{171}$, en lo que les siguieron Elbern, Manzanares, Nieto Alcaide y Noack-Haley ${ }^{172}$. Sepúlveda González apuntó tres posibilidades: reserva eucarística, relicario o caja portaevangelios ${ }^{173}$. Cid Priego se inclinó por la reserva eucarística o relicario ${ }^{174}$. Finalmente, Bango Torviso ha retomado la sugerencia de Gómez Moreno y Sepúlveda, definiéndola como caja portaevangelios ${ }^{175}$.

La medida del contenedor interior $-38,4 \times 23,3 \times 6,6 \mathrm{~cm}-$ es el primero de los rasgos que debe tenerse en cuenta para la determinación de la función inicial (Figs. 9-10). Como hemos visto, supera notablemente las dimensiones habituales de los

167 G. SCHUPPENER, Germanische Zahlwörter. Sprach- und kulturgeschichtliche Untersuchungen insbesondere zur Zahl 12, Leipzig, 1996, esp. pp. 85-94.

168 Ibid., pp. 111-155.

169 Op.cit., p. 379.

170 Ibid., p. 328 y n. 1.

171 J. CUESTA FERNÁNDEZ y M. DÍAZ CANEJA, op. cit. (1958), p. 15.

172 V.H. ELBERN, op. cit. (1961), p. 179; J. MANZANARES RODRÍGUEZ, op. cit., 1972, p. 18; V. NIETO ALCAIDE, op. cit., 1989, p. 174; S. NOACK-HALEY, op. cit., 1993, p. 143, у op. cit., 1999, p. 185.

173 M.A. SEPÚLVEDA GONZÁLEZ, op. cit. (1989), p. 150.

174 C. CID PRIEGO, op. cit. (1995-1996), p. 28.

175 I.G. BANGO TORVISO, op. cit., 2001, p. 302. 
relicarios altomedievales, así como a las de los recipientes destinados a la reserva eucarística, que en este tiempo se aloja en píxides o arquetas de muy inferior tamaño, como las píxides de marfil tardoantiguas o carolingias ${ }^{176}$, los abundantes crismales al servicio de los óleos o la reserva eucarística ${ }^{177}$, o cajitas del tipo de la arqueta del obispo Arias (Museo de la Iglesia, Oviedo) ${ }^{178}$. Ello es debido a la escasez material de la reserva eucarística en tiempos anteriores al s. XII, muy limitada a las necesidades del viático y comunión de enfermos, con la excepción de la liturgia de los presantificados del Viernes santo ${ }^{179}$. Los recipientes se adecuan al volumen del pan reservado, muy reducido.

Por otro lado, los relicarios portátiles altomedievales, en Occidente hasta el umbral del 1200, ocultan por lo general la reliquia y no son en principio accesibles ${ }^{180}$, lo que contradice la continua posibilidad de apertura que ofrecen las cajas de Oviedo y Astorga, desprovistas de cierre. De hecho, en algunos casos en los que se han publicado las observaciones estratigráficas sobre la construcción del relicario, la disposición de los clavos sobre la placa o lámina de cierre del sepulchrum excluye toda posibilidad de apertura del mismo mediante lámina corredera ${ }^{181}$. En relación con este cierre del relicario altomedieval, se ha observado la recurrencia iconográfica de imágenes y motivos apotropaicos (trenzas, animales monstruosos disminuidos y humillados...) sobre estas placas de clausura, en evidente coherencia con la voluntad de preservar y garantizar su sellado ${ }^{182}$. Dada la extraordinaria calidad material y el equipamiento de pedrería de que goza la Arqueta de las Ágatas, hay que excluir todo parentesco formal y funcional con los contenedores metálicos de reliquias destinados a la ocultación bajo altares o en sepulcros pétreos, de época tardoantigua, como los abundantes

176 Corpus de estas piezas en W.F. VOLBACH, op. cit., 1976. En lo referente a las prácticas de reserva eucarística, fundamentalmente para la administración de la comunión a los enfermos y para el viático, vid. el exhaustivo estudio de O. NUSSBAUM, Die Aufbewahrung der Eucharistie, Bonn, 1979, pp. 99-101, y esp. 308-364. En las pp. 110-111 expresa dudas sobre que las referidas píxides hubieran efectivamente servido para albergar la eucaristía, siquiera reaprovechadas de un uso anterior. La materia -marfil, de origen animal-, podría haber sido obstáculo para su uso eucarístico, pudiendo haberles sido aplicado el reparo que la normativa canónica desde fines del VIII puso al empleo del hueso como materia en la cual elaborar cálices y patenas. El uso de píxides ebúrneas es seguro desde fines del XII (ibid., p. 112, n. 80, y p. 124).

177 V.H. ELBERN, "Baptizatus et confirmatus. Ein neuer Beitrag zum frühmittelalterlichen Chrismale", P. SKUBISZEWSKI (ed.), op. cit., 2008, pp. 431-451, y "Ein frühmittelalterliches Chrismale in New York”, Arte medievale, N.S. I, 2 (2002), pp. 9-24; D. QUAST, op. cit., 2012, pp. 45-49. La diferencia teórica funcional entre relicarios y crismales es la posibilidad de apertura a voluntad de su cubierta, que solamente habría de darse en estos últimos. No obstante, se dan casos de relicarios identificados por su inscripción como tales con tapa practicable. Al respecto vid. la tabla descriptiva en ibid., p. 59, Abb. 51.

178 J. MANZANARES RODRÍGUEZ, op. cit., 1972, pp. 28-29.

179 Sobre todo ello, O. NUSSBAUM, op. cit., 1979, esp. pp. 36-61 y 75-101.

180 G. TOUSSAINT, "Die Sichtbarkeit des Gebeins im Reliquiar- eine Folge der Plünderung Konstantinopels?”, B. REUDENBACH y G. TOUSSAINT (eds.), op. cit., 2011, pp. 89-106.

181 Por ejemplo el caso de Ennabeuren: D. QUAST, op. cit., 2012, p. 11.

182 Ibid., p. 33-34; V.H. ELBERN, "Heilige, Dämonen und Magie an Reliquiaren des frühen Mittelalters", Santi e demoni nell'Alto Medioevo Occidentale. Secoli V-XI, Spoleto, 1989, pp. 956-957. En el plano simbólico, podría, a título hipotético, asimilarse a esta concepción la ya mentada presencia de la Cruz en los reversos o bases de las estaurotecas bizantinas y las propias cajas ovetense y astorgana. De hecho, la Cruz es denominada pessulum crucis en el Comentario al Apocalipsis de Beato de Liébana (XI, 4; BEATO DE LIÉBANA, op. cit., 1995, p. 612), cerrojo que sella la prisión del Anticristo. 
ejemplos documentados en la Europa balcánica, ámbito alpino oriental y península anatólica ${ }^{183}$.

En apoyo de su tesis, Gómez Moreno citó la donación del obispo Sisnando al monasterio de Sobrado dos Monxes, del 30 de diciembre de 955, donde se nombra a una "capsam evangeliorum similiter argenteam solidos $\mathrm{Cm}$ deauratam lapidibus preciosis ornatam" "184. También hizo referencia a la donación de Ordoño II a la catedral de Santiago de Compostela, el 20 de abril de 911, donde se incluyen

"cabsas duas ex auro obtimo cum lapillis et margaritis miro opere compositas et cum nomine nostro. Aliam ex vitro transmarino in arcos dispositam" 185 .

Podemos añadir las siguientes menciones: donación del abad Diego al monasterio de San Antolín in villa Guimir, de 28 de enero de 1026: crucem et capsam evangelistarum argenteis ${ }^{186}$; solicitud de confirmación de los bienes del monasterio de Calvor por parte del arcipreste Teodenando ante Alfonso III, 1 de enero de 902: capsa evangelistarum $^{187}$; dotación fundacional de los monasterios de San Pedro de Montes, San Andrés de Montes y Santiago de Peñalba por parte del obispo Genadio de Astorga, en 915:

"ecclesiae Sancti Petri offero calicem cum patena insuper evangeliarium et coronas argenteas (...) ecclesiae Sancti Iacobi (...) coronam et insuper evangeliare argenteum" 188 .

Por su parte el Testamentum de 16 de noviembre de 812, por el que Alfonso II dotó la basílica de San Salvador de Oviedo recoge un "superevangeliare ex palleo", ${ }^{189}$ pieza de tela rica destinada a cubrir el códice neotestamentario, quizás para envolverlo antes de ser introducido en la capsa. En el mismo sentido quizás haya que interpretar los paños "super evangeliares maiores IIII y minores IIII" donados por Teoda y Aragonti al monasterio de Santa María de Piasca el 25 de julio de $930^{190}$. De hecho, el Ordo scrutinii de la liturgia franco-romana, llevado a cabo mediada la Cuaresma (Sacramentarium Fuldense, ${ }^{\circ}$ 473), indica que tras la lectura del evangelio, "suscipiat subdiaconus ab eo (sc. diaconus) ipsum librum super linteum et portet in

183 D. QUAST, op. cit., 2012, pp. 55-58, Abb. 49. Cf. H. BUSCHHAUSEN, Die spätrömischen Metallscrinia und frühchristlichen Reliquiare. I Teil: Katalog, Viena, 1971.

184 P. LOSCERTALES Y GARCÍA DE VALDEAVELLANO, Tumbos del monasterio de Sobrado de los Monjes, Madrid, 1976, I, nº 2, pp. 23-26.

185 M. LUCAS ÁLVAREZ, Tumbo A de la catedral de Santiago. Estudio y edición, Santiago, 1998, doc. 21, pp. 77-79.

186 Tumbo de San Julián de Samos, ed. M. LUCAS ÁLVAREZ, El Tumbo de San Julián de Samos (siglos VIII al XII), Santiago de Compostela, 1986, $\mathrm{n}^{\circ}$ 7, pp. 74-79.

187 Ibid., n 33, pp. 119-122.

188 G. CAVERO DOMÍNGUEZ y E. MARTÍN LÓPEZ, Colección documental de la catedral de Astorga I (646-1126), León, 1999, $\mathrm{n}^{\circ} 12$, p. 67.

189 S. GARCÍA LARRAGUETA, Colección documental de la catedral de Oviedo, Oviedo, 1962, $\mathrm{n}^{\circ} 2$, p. 6.

190 J.M. MÍNGUEZ FERNÁNDEZ, Colección diplomática del monasterio de Sahagún (siglos IX y X), León, 1976, nº 39, p. 74. 
sacrarium" ${ }^{191}$. Y en el contexto del Ordo obseruandus in functione episcopi, (Liber Ordinum aepiscopalis, XLIIII), se prescribe que una vez vestido el cadáver del obispo difunto, se coloque sobre su pecho "euangelium super palleum agnabum", que será recogido por el diácono en el momento de la inhumación ${ }^{192}$.

En el Imperio carolingio disponemos de otras y más explícitas referencias documentales: en los Gesta abbatum Trudonensium, Continuatio I, c. 2, se inventarían en el año 870 unas capsas evangelicas argento paratas ${ }^{193}$; el Anonymus haserensis, autor de De episcopis Eistetensibus (Eichstätt), atribuye al obispo Geroch, en noticia fechada en 781, la ornamentación de "veterem illam evangeliorum capsam ex electro et auro purissimo gemmiisque pretiosis" ${ }^{194}$; la Vita Angilberti, 7, atribuye al abad centulense (790-799) la dotación de la abadía con un espléndido tesoro sacro, en el que cita "capsas evangelii" "195; por último, los Gesta abbatum Fontanellensium, 15, asignan al abad Wido (753-787) la donación de una "capsam evangeliorum paratam"196.

Por sus dimensiones y la robustez de su confección, la caja es capaz de acoger un gran códice altomedieval. Por la riqueza de su confección y materiales y la carga teológica que encierra la disposición de estos, no cabe dudar de que exclusivamente pudo haber sido destinada a guardar un texto bíblico, y fundamentalmente, un evangeliario, a juzgar por los estrechos paralelos compositivos que la tapa presenta con las cubiertas de las encuadernaciones orfebrísticas altomedievales, en su inmensa mayoría destinadas a cubrir evangeliarios y en menor proporción, salterios. La consiguiente pregunta es obvia: ¿hubo evangeliarios en Asturias en el s. IX? La respuesta es afirmativa: el Liber Iusti, cuyo texto ha sido recientemente reconstruido y analizado. Se trataba de un códice con los cuatro evangelios, compuesto por un notario llamado Iustus, fallecido en $812^{197}$. Nada sabemos de sus dimensiones, pero nos puede orientar al respecto el tamaño de la Biblia de Danila, conservada en la biblioteca de la Abadía de la Santísima Trinidad de Cava dei Tirreni (Ms 1): 315/320 x 262/272 mm, códice del que los recortes que se advierten permiten reconstruir unas dimensiones máximas de $330 / 335 \times 270 / 280 \mathrm{~mm}^{198}$.

El peso de la tapa hace que la caja pierda el equilibrio y se vuelque hacia atrás en cuanto se sobrepasa la vertical hacia atrás, por lo que es necesario sostener en todo

191 Sacramentarium Fuldense, feria IIII post medium Quadragesimae. Ordo scrutinii. Ed. G. RICHTER, Sacramentarium Fuldense Saeculi X, Fulda, 1912, p. 337. Similar proceder se observa en el Ordo vel denuntiatio scrutinii ad electos quod tertia ebdomada in Quadragesima, secunda feria, initiatur, del Pontificale romanogermanicum: "Et postquam legerit, subdiaconus suscipit de eo (sc. diaconus) ipsum evangelium super linteum et portat in sacrarium" (ed. C. VOGEL y R. ELZE, Le Pontifical romano-germanique du Xe siècle, Ciudad del Vaticano, 1963, II, n 137 , p. 32).

192 J. JANINI CUESTA (ed.), Liber ordinum episcopal (Cod. Silos, Arch. Monástico 4), Santo Domingo de Silos, 1991, nº 257-258, pp. 141-142.

193 J. VON SCHLOSSER, op. cit., 1988, nº 261, p. 75.

194 Ibid., n ${ }^{\circ} 506$, p. 158.

195 Ibid., $\mathrm{n}^{\mathrm{o}} 785$, p. 260.

196 Ibid., nº 865 , p. 288.

197 J.A. VALDÉS GALLEGO, "Iusti Liber (Los Evangelios de Oviedo)”, A. GARCÍA LEAL (coord.), op. cit., 2012, pp. 453-482.

198 P. CHERUBINI, "La Biblia de Danila", La Biblia de Danila (Codex Biblicus Cavensis, Ms 1 de la abadia de la Santísima Trinidad de Cava dei Tirreni). Estudios, Oviedo, 2010, p. 49. 
momento la tapa con las manos mientras se abre. Esta limitación implica forzosamente que la caja nunca pudo estar destinada a la exposición del objeto guardado en el interior, es decir, que su posición natural, para la que fue concebida y hecha, es la del cierre, estable precisamente por el peso de la tapa. Entonces, cabe preguntarse por el sentido y uso de esta caja. Un indicio sólido ofrece al respecto el Pseudo-Alcuino (De divinis officiis, 14), en cita referida a la procesión del Domingo de Ramos:

"Deinde sucipiunt diaconi suprascriptum portatorium cum Evangelio ... praecedente aqua benedicta cum candelabris atque thymiameteriis cum aliis ornamentis" 199.

El rito corresponde al segundo Ordo in die palmarum que recoge el Pontificale romano-germanicum: "Hodie praeparatur quoddam portatorium honestissimum in quo intromittitur sanctum evangelium, quod intelligitur Christus". Tras la bendición de los ramos, "sucipiunt diacones suprascriptum portatorium cum evangelio" 200 . Aunque por portatorium se ha de entender las angarillas o parihuela en las que era llevado el códice del evangelio, se supone que este no era expuesto a la intemperie, sino que debía ser protegido en una caja a colocar sobre las angarillas o bien en el propio receptáculo cubierto, a modo de litera. Ambas soluciones son posibles y corresponden bien al significado del verbo utilizado, intromittere.

Otro se encuentra en el Ordo hispánico de UI feria in Parascefen (Liber Ordinum aepiscopalis, LXXXIIII), cuando, a la hora de nona, retomando el oficio, el lignum crucis es llevado por el diácono al altar "precedendo episcopum ante euangelium sine cooperturio" 201 , contexto en el que hay que entender que en esta ocasión el Evangeliario era llevado expuesto, sin cubierta o velo, lo que implica que en otras ocasiones el recorrido se hacía con el códice cubierto por velo o inserto en caja. La caja funciona como contenedor del códice en una procesión solemne, que hace efectiva la memoria de la presencia real del Señor, simbólicamente representado por su Palabra.

Habida cuenta de que el orden de los diáconos es al que compete la proclamación del Evangelio, como explícitamente atestigua la Confirmatio post ordinatvm diaconem del rito hispánico (Liber Ordinum aepiscopalis, XIIII), según la cual, tras ser ordenado, el obispo le entrega al nuevo levita el evangelio, diciendo: "ecce fili evangelium Christi accipe, ex quo annunties bonam gratiam fideli populo" ${ }^{202}$, es razonable identificar tanto la caja ovetense como la astorgana con estos contenedores portaevangelios encomendados a los diáconos.

199 O. NUSSBAUM, op. cit., 1979, p. 146, n. 333. El testimonio, fechado en el X, está en el origen de las procesiones de Ramos, en las que el protagonista era una imagen de Cristo, a la que se rendía la reverencia debida, como si de su propia persona se tratara.

200 Ed. C. VOGEL y R. ELZE, op. cit., 1963, II, n 195-198, pp. 51-52 y nota a los n ${ }^{\circ} 195-201$.

201 J. JANINI CUESTA (ed.), op. cit., 1991, nº 395, p. 181.

202 Ibid., n 91, p. 93. 